\title{
شرط المال في هدنة الإمام الصسن (ع)
}

\author{
أ.د. علي صالح رسن الحمداوي. \\ جامعة البصرة، كلية التربية، العلوم الإنسانية. \\ رقم الموبايل: 07714979720
}

ali.saleh@uobasrah.edu.iq البريد الاكتروني

ملخص البحث

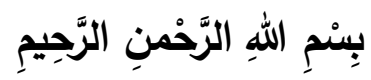

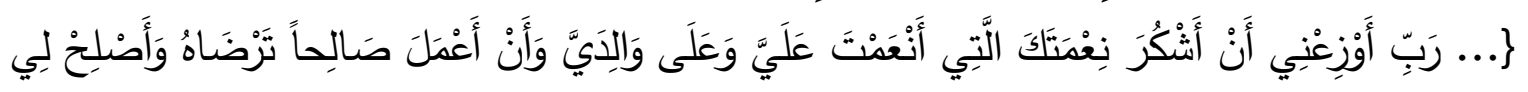

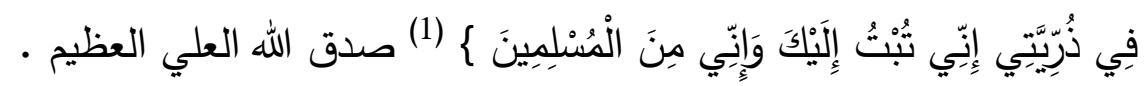

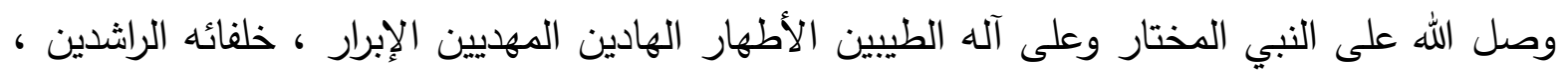

أمير المؤمنين ، والحسن والحسين والتسعة المعصومين من ذرية الحسين (عليهم السلام) .

وبعد ...

من الأساسيات Basics في الموضوع معرفة المال ، ولماذا التركيز عليه أهو مهماً إلى هذا الحد ؟

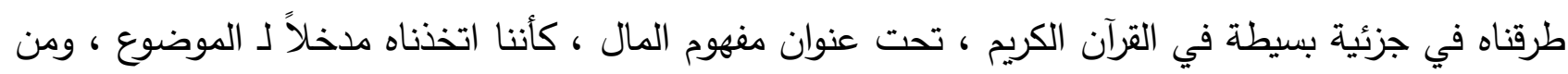

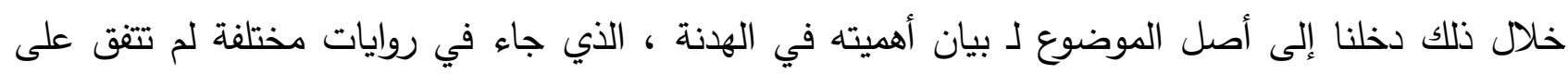

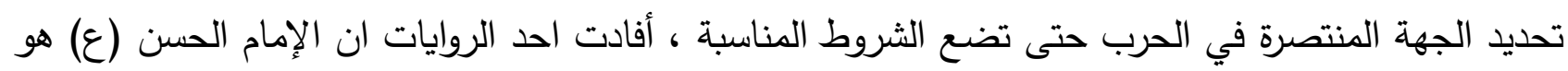

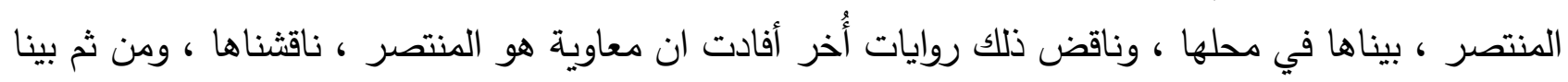

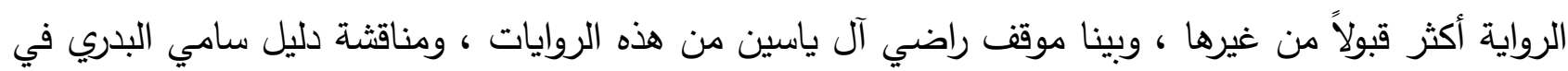

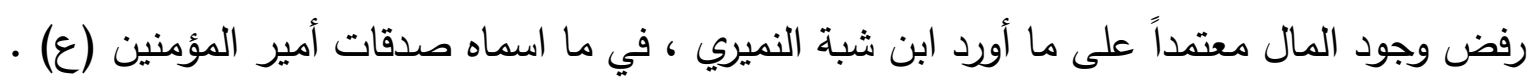

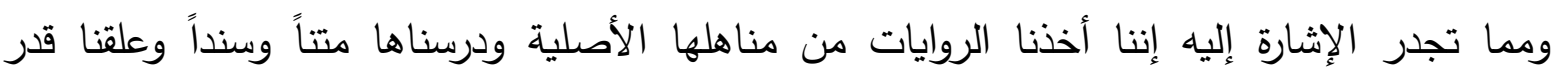

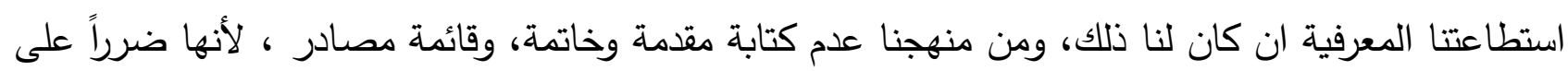

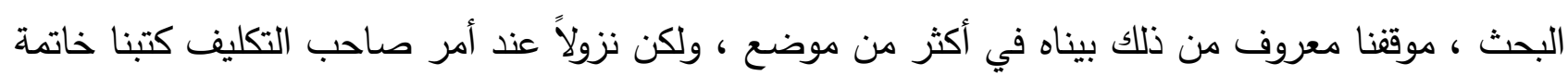

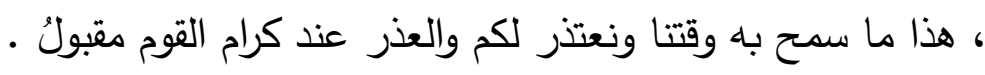




\title{
The Condition of Money in the Truce of Imam Al-Hassan(PBUH)
}

\author{
Prof. Dr Ali Salih Resin Al-Mohamdawi \\ College of Education for Human Sciences-University of Basrah \\ Mobile number: 07714979720 \\ Email: ali.saleh@uobasrah.edu.iq
}

In the Name of Allah, the most Beneficent, the most Merciful

"O my Lord! so order me that I may be grateful for Thy favours, which thou hast bestowed on me and on my parents, and that I may work the righteousness that will please Thee: And admit me, by Thy Grace, to the ranks of Thy righteous Servants."Al-Ahqaf (15)

To Allah Almighty has spoken the truth

Praise be to Allah, Lord of the worlds, and may Allah's prayers be upon His faithful Messenger and upon his good and pure family, from whom Allah has removed filth and purified them.

Knowing money is one of the principles that why is focusing on it so important? We approached it in a simple part in the Holy Qur'an, under the title of the concept of money, as if we took it as an introduction to the topic, and through that we entered the origin of the topic to explain its importance in the truce, which came in various narrations that did not agree on defining the victorious party in the war in order to set the appropriate conditions. One of the narrations stated that Imam Al-Hassan (pbuh) was the victor, and we showed it in its place, and this contradicted other narrations which stated that Muawiyah was the victor. In refusing to find money based on what Ibn Shabat al-Numairi reported, in what he called the charity of the Commander of the Faithful (PBUH). 
It is worth noting that we took the narrations from their original sources, studied them closely and in support, and commented as much as we can cognitively if we had that, and from our methodology not to write an introduction, conclusion, and a list of sources, because it is harmful to the research, our position is known about that. The order of the author of the assignment is a conclusion. This is what our time allows, and we apologize to you.

The concept of money in the Holy Quran ، مفهوم المال في القرآن الكريم

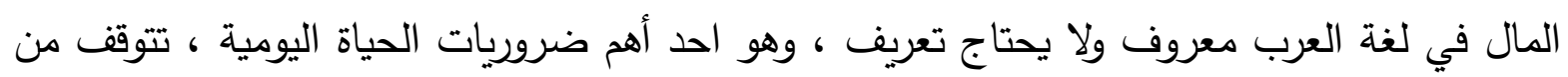

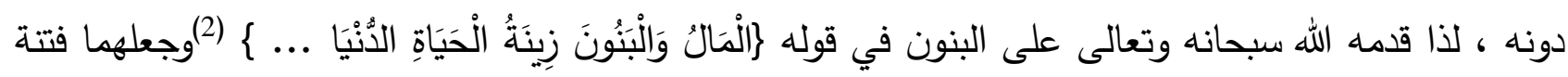

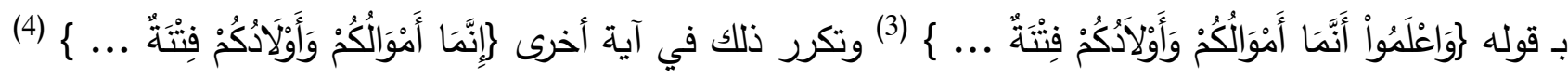

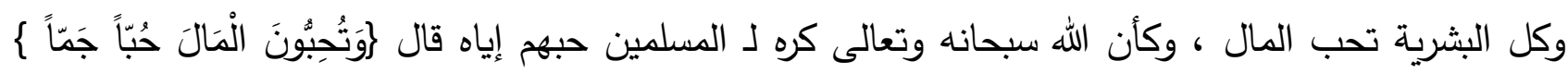

ومهما كان المال والأولاد ، يجب ان لا يلهيا أصحابهما عن ذكر الله ، جاء ذلك بـ قوله تعالى ريَا أَيَهَا

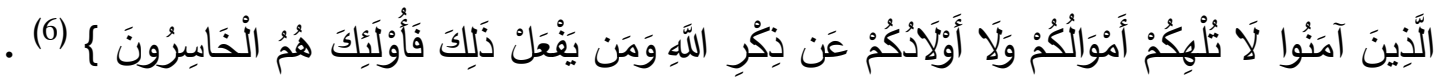

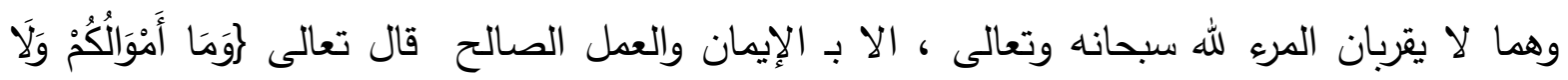

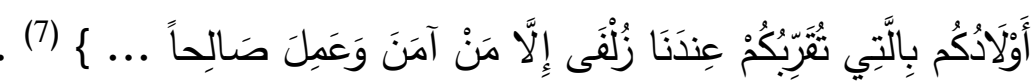

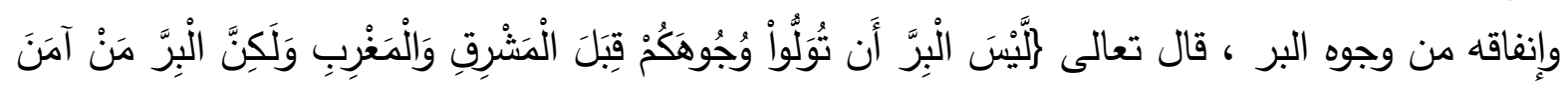

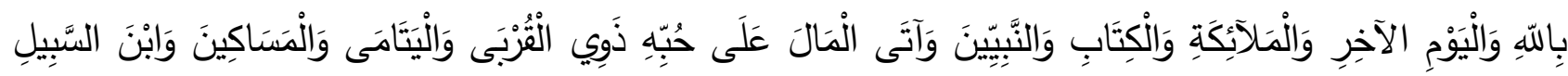

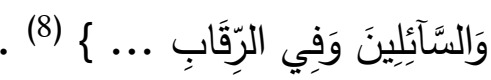

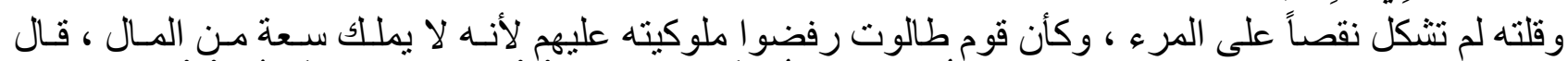

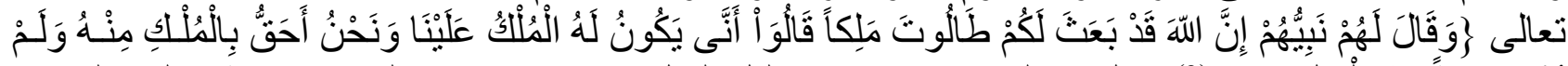

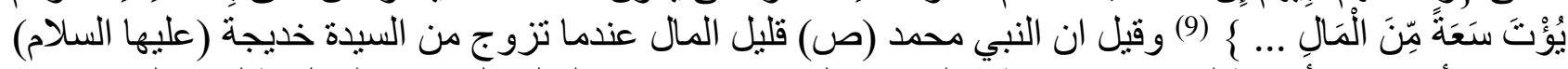

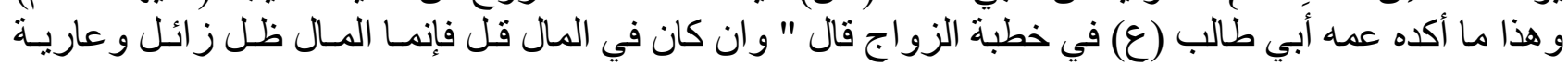
مسترجعة " (10)

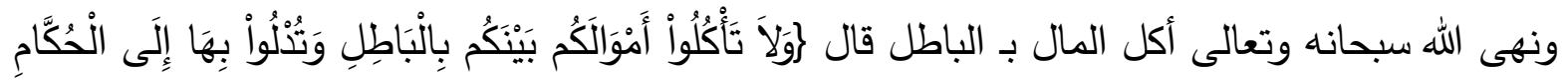

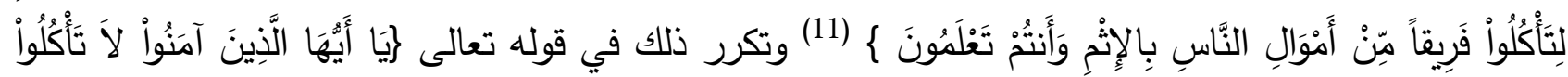

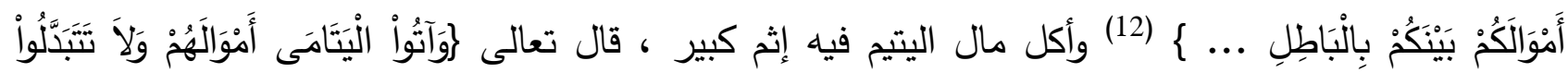

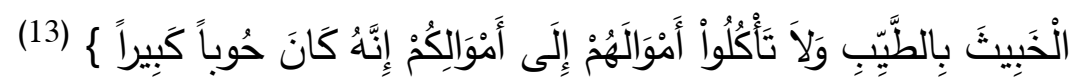




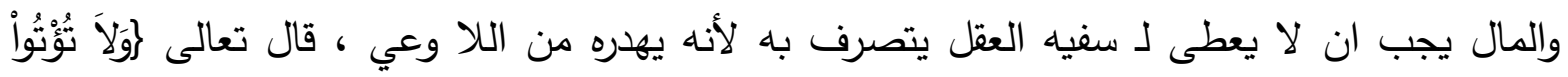

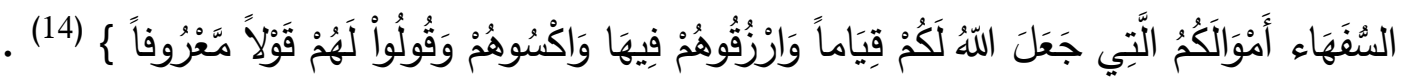

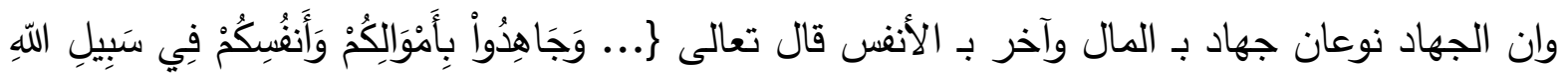

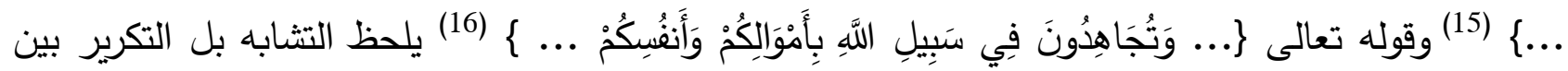
الآيتين

والمال فيه حصانة لـ المرء ان أراد الحصانة الزوجية ولم يرد البغاء ، وكأن المراد به إعطاء المهر

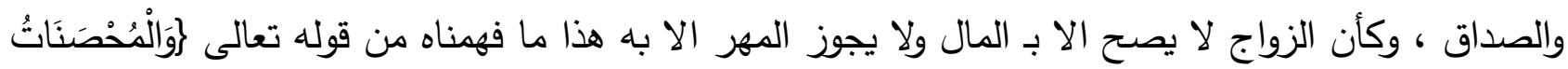

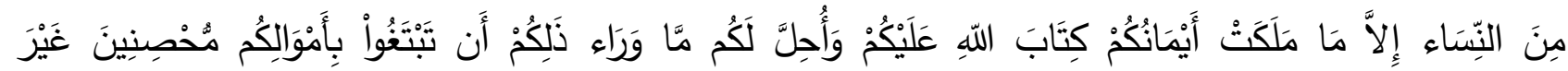

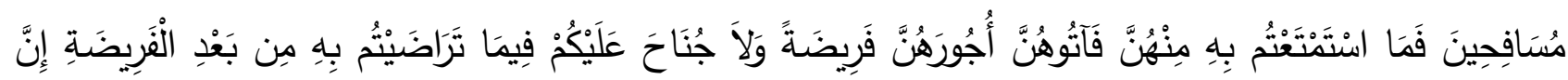

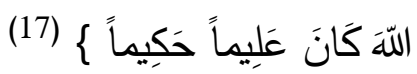

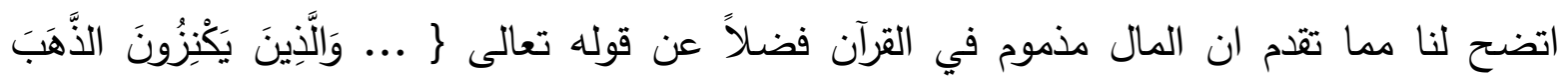

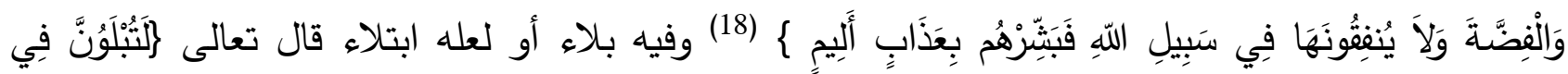

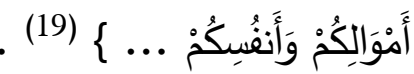

المراد من كل ما تقدم أهمية المال في هدنة الإمام الحسن (ع) ورد ذلك في روايات :

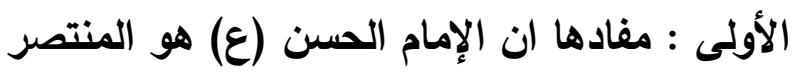

\section{The first: to the effect that Imam Al-Hassan (PBUH) is the victor}

رواها البخاري بـ سند مختلط قال : حدثنا عبد الله بن محمد حدثا سفيان عن أبي موسى قال : سمعت

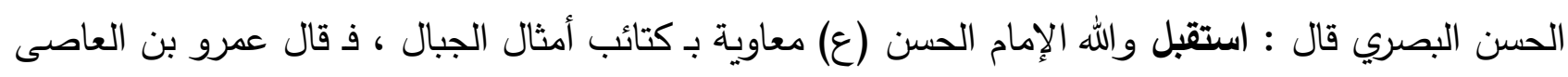

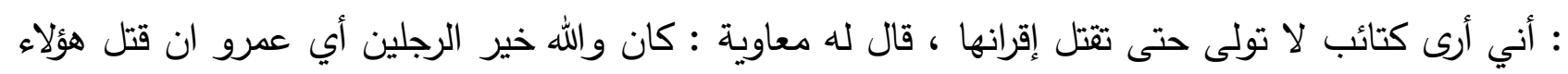

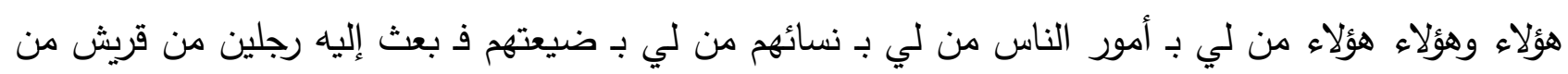

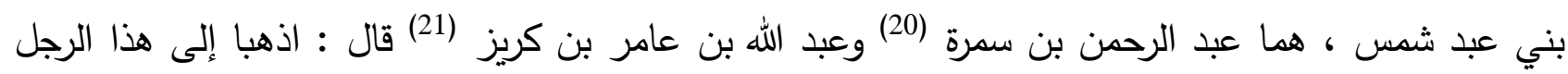

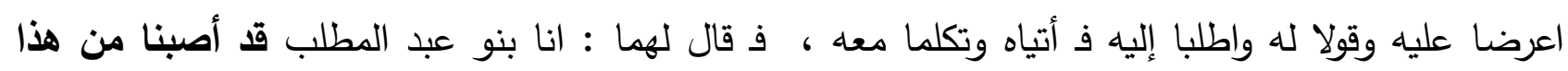
المال وان هذه الأمة قد عاثت في دمائها (22) . ما نريد قوله ان الراوي اخفق في استعمال أول كلمة فيها " استقبل " ومنها الاستقبال ديوان الضيافة

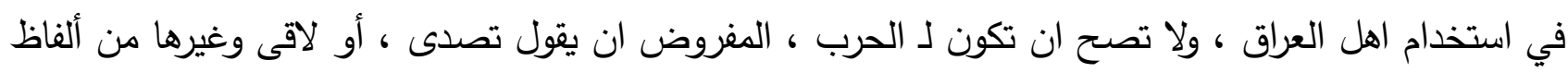

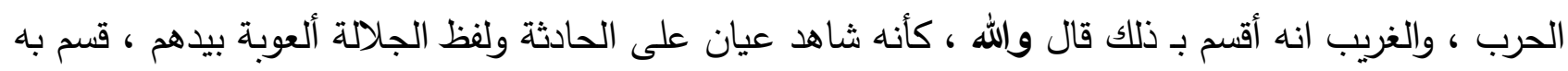

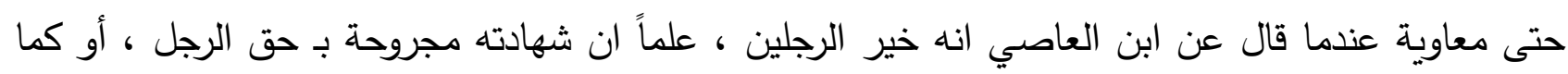

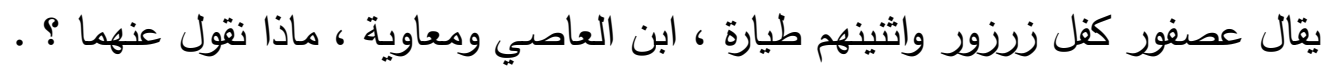


ظهر من الرواية ان الإمام الحسن (ع) هو المنتصر ، دل ذلك من وصف كتائب جيشه كأنها الجبال ،

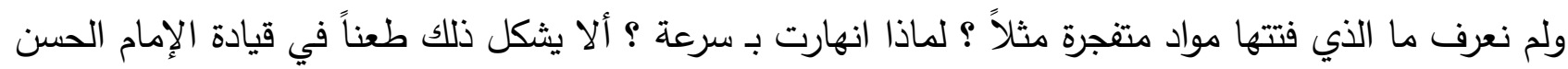
(ع) ؟ وقد دب الرعب في نفس العاصي بن العاصي ، لـ ذلك اشار على معاوية في طلب الهدنة، وبدوره أثنى

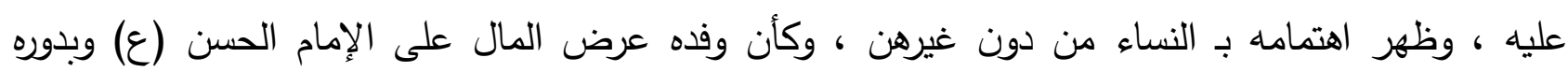

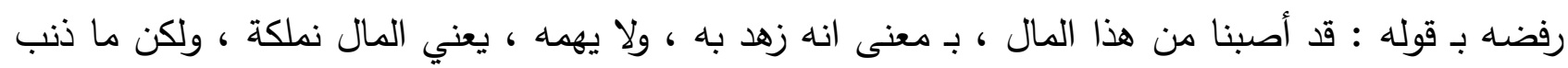

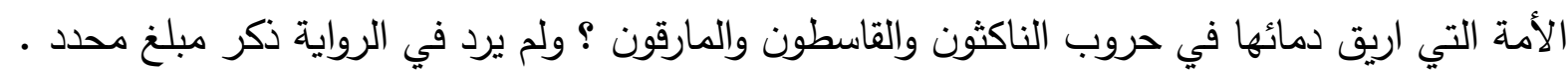

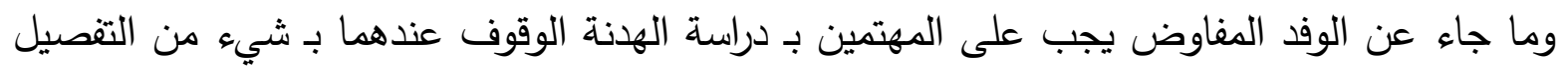

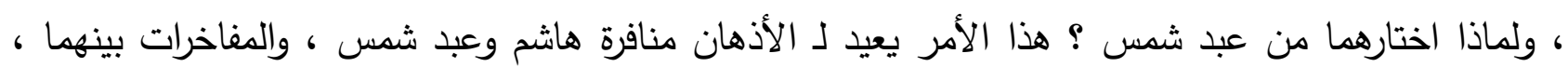

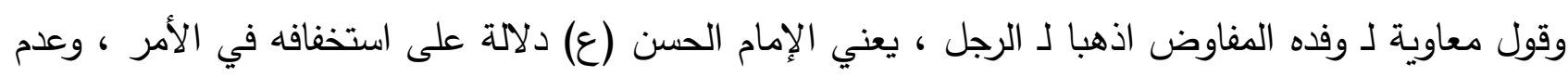

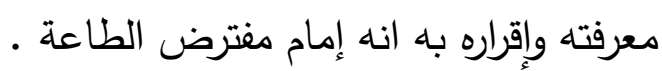

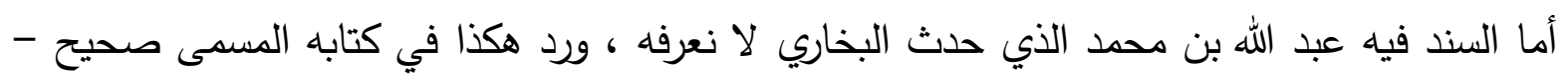

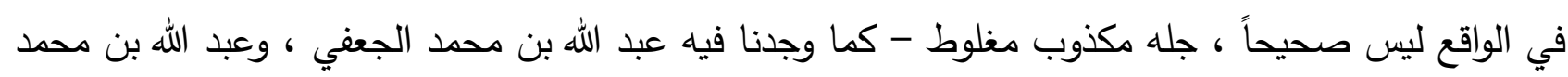

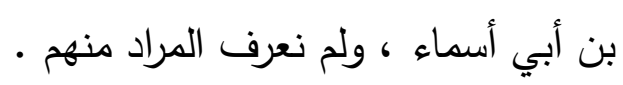

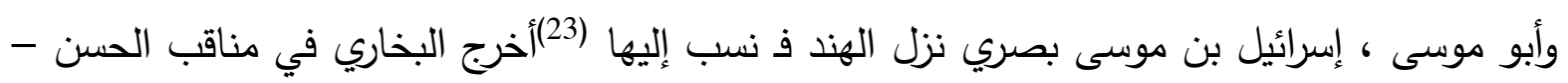

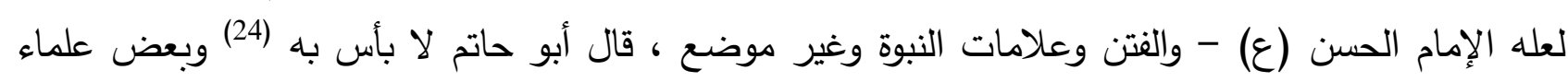

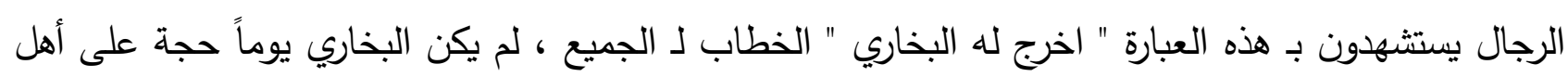

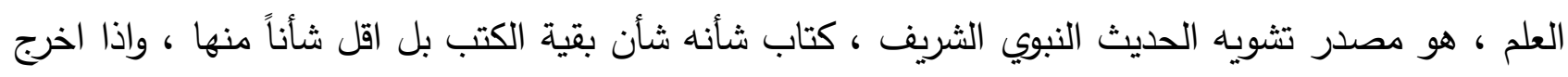

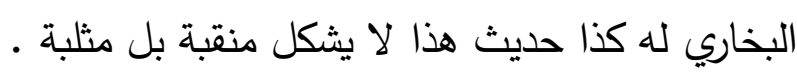

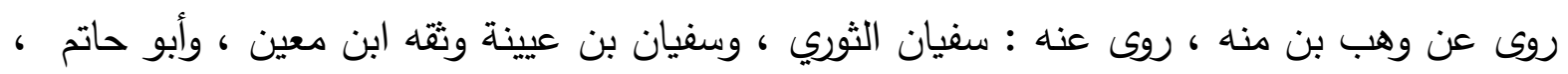

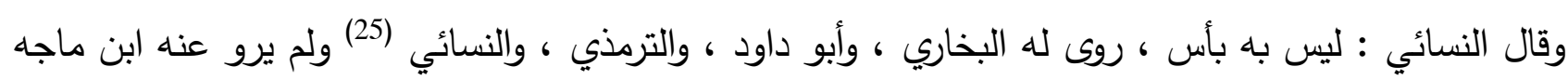

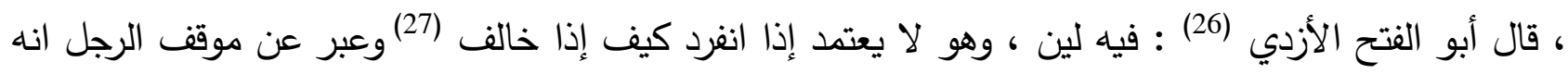

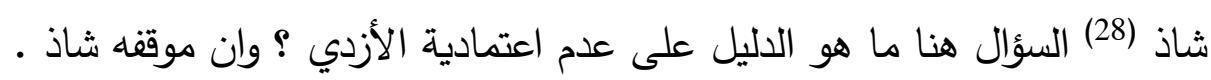

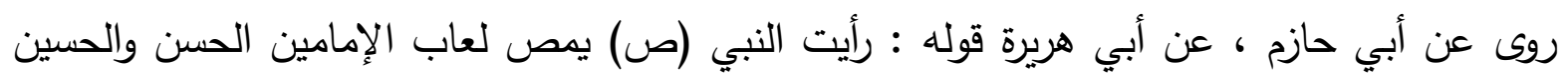

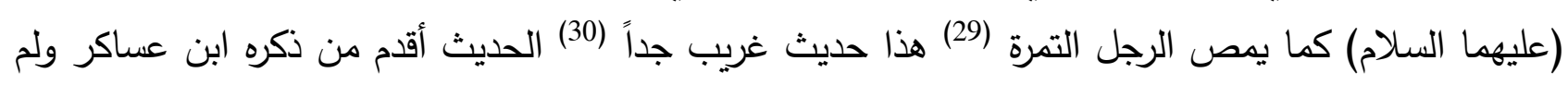

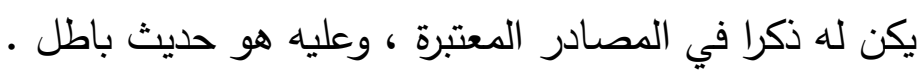

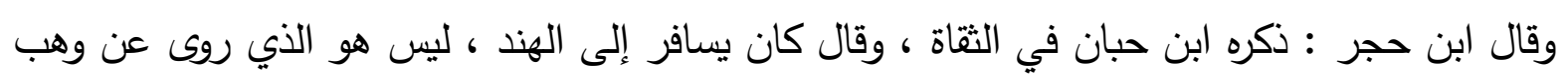
بن منبه وروى عنه سفيان الثوري ذاك شيخ يماني قد فرق بينهما غير واحد (31) .

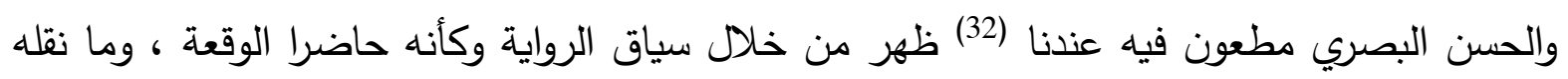

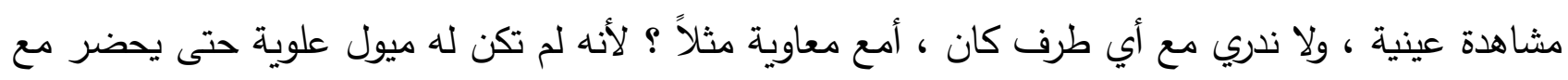


الإمام الحسن (ع) ثم انه بصري ، ما الذي جعله ان يكون حاضراً هناك ، أهو اعلامياً مثلاً أراد توثيق ما

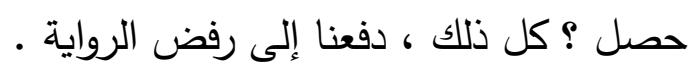
رواية الحاكم النيسابوري

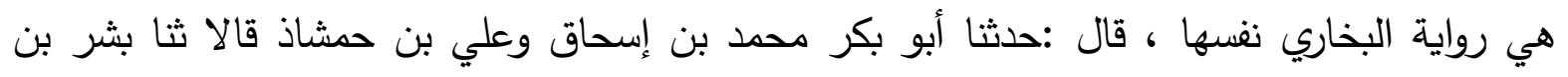

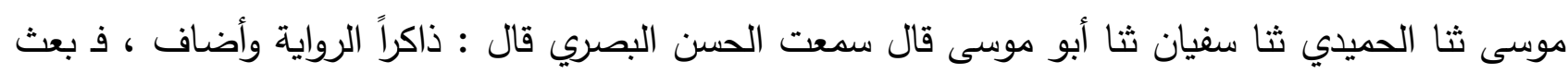

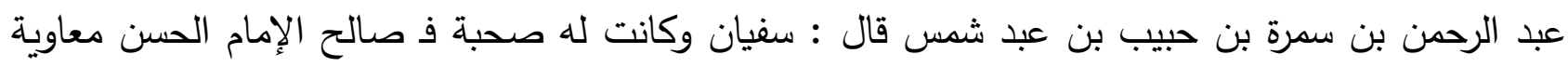

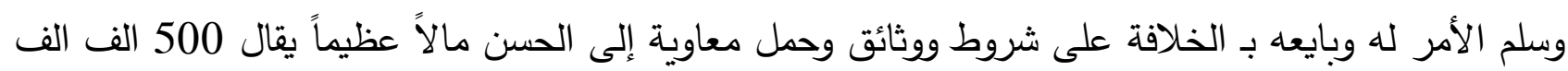

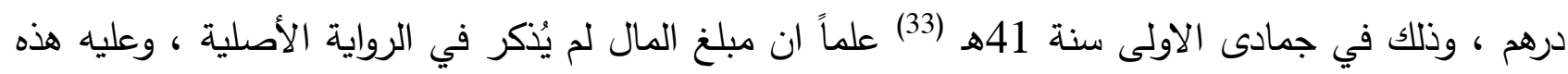

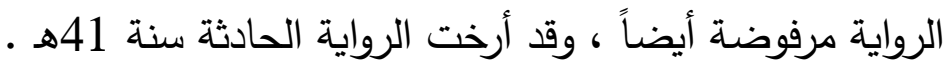

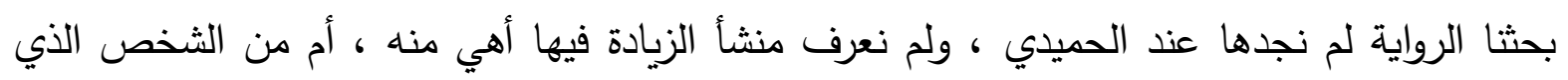
نسبها إليه ؟ وان بشر بن موسى الوارد في رواية البخاري رواها عن سفيان مباشرة وفي هذه الروائ الرواية جعل بينهما

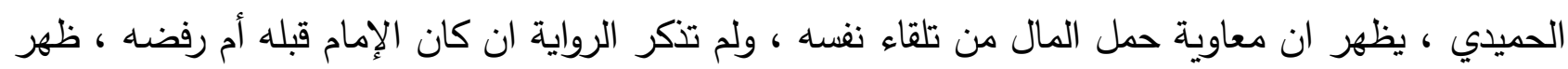

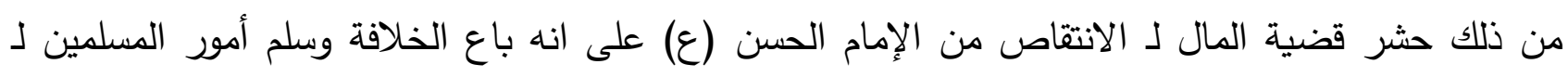

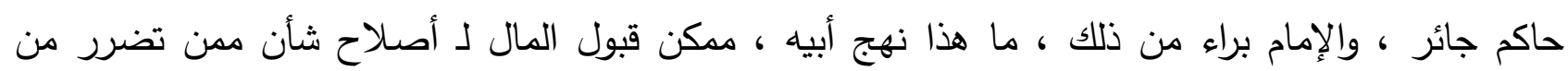

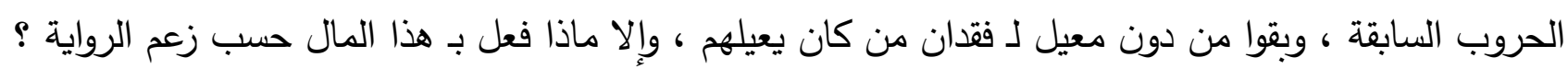

الثانية : مفادها ان الإمام الحسن (ع) هو الطرف الخاسر ،

\section{The second: the effect that Imam Al-Hassan (PBUH) is the loser}

هذا الأمر فيه روايات ، أ : لما رأى الإمام الحسن (ع) من أصحابه الفشل أرسل إلى عبد الله بن عامر الصا

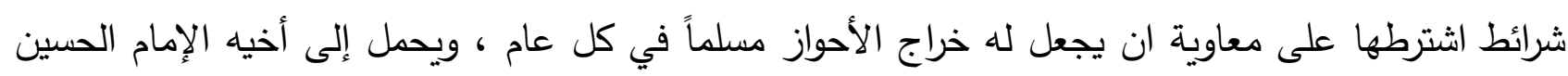

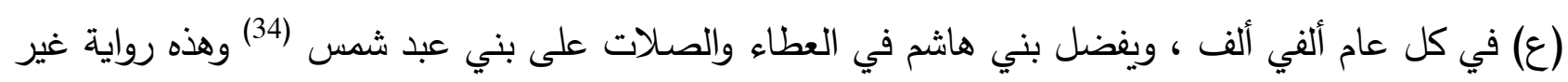

وما ورد فيها من ضعف قوة الإمام الحسن (ع) هذا صحيح بـ دلالة جنوحه لـ الهدنة ، ولكن ما هو

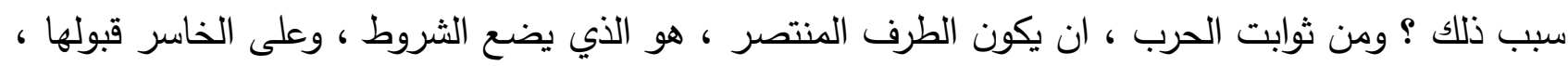

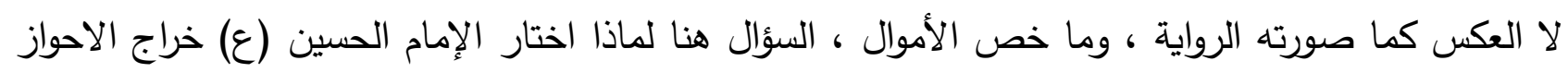

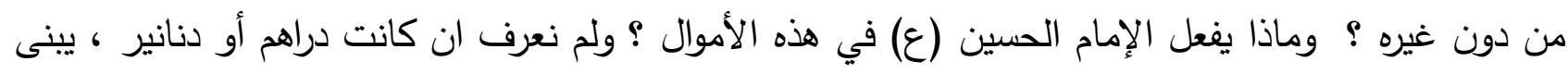

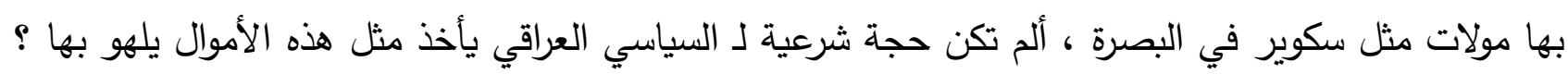

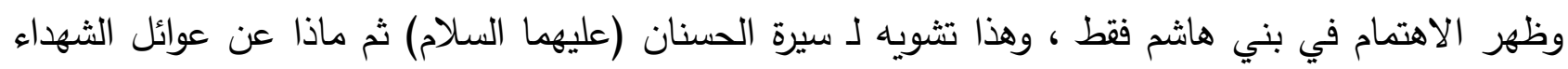


الذين سقطوا في معارك الناكثون والقاسطون والمارقون ؟ من يعيلهم ، وتفضيل هاشم على عبد شمس قديم ، لا

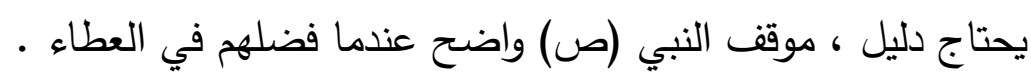

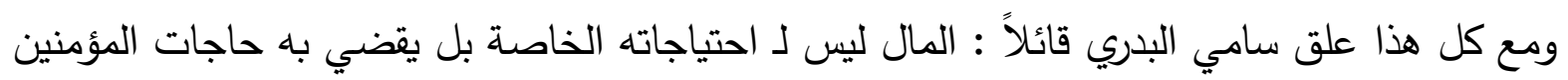

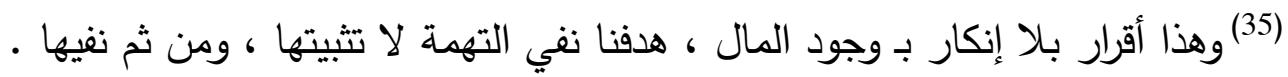

حدثي موسى بن عبد الرحمن المسروقي حدثا عثمان بن عبد الحميد أو ابن عبد الرحمن المجازي

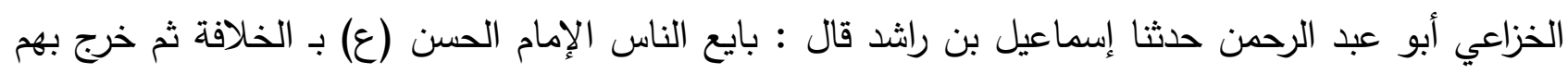

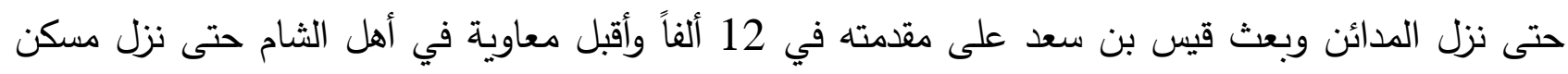

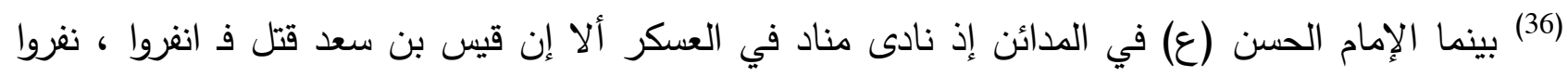

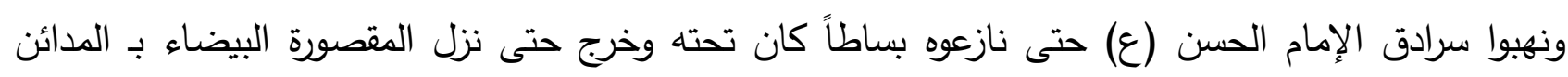

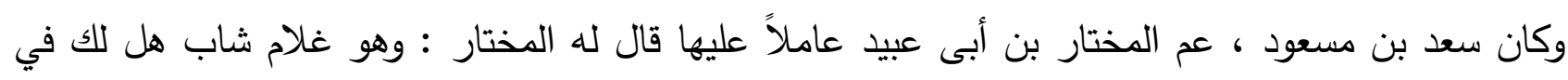

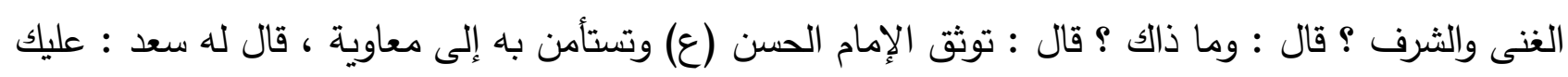

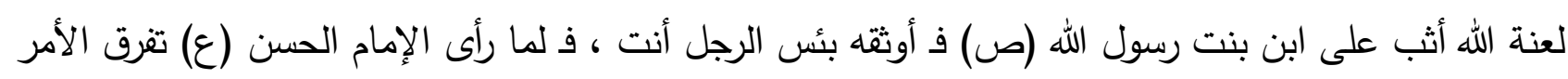

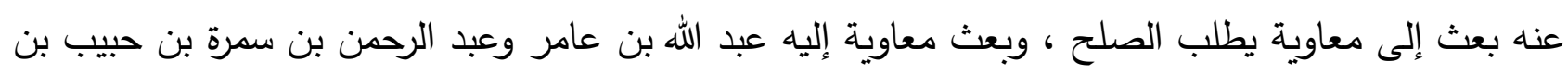

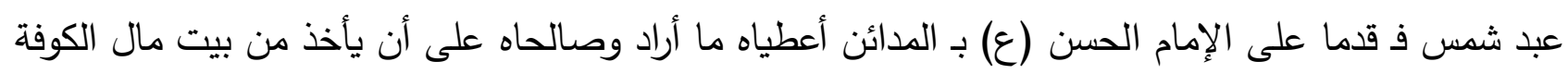

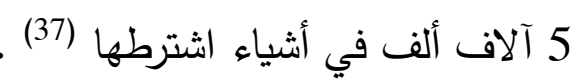

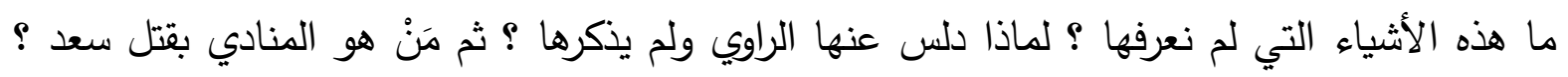

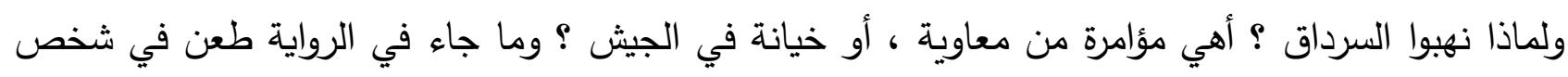

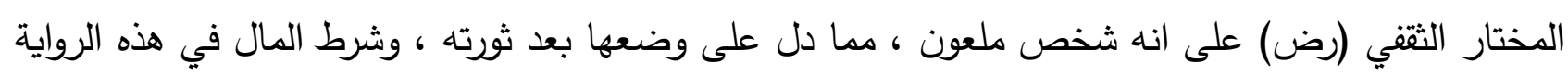

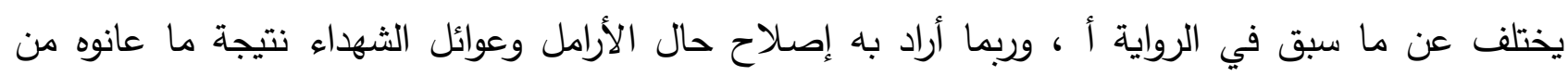

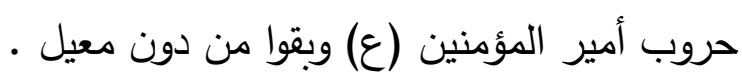

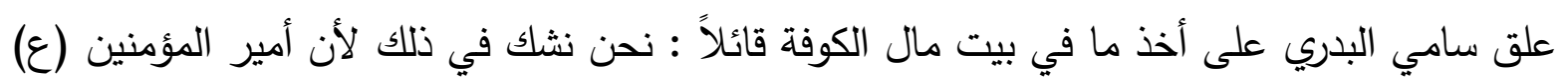

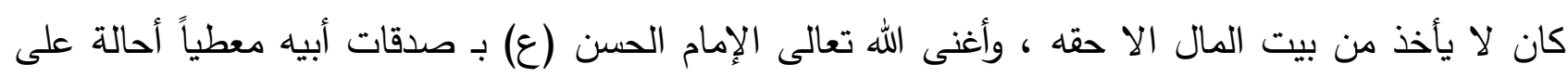

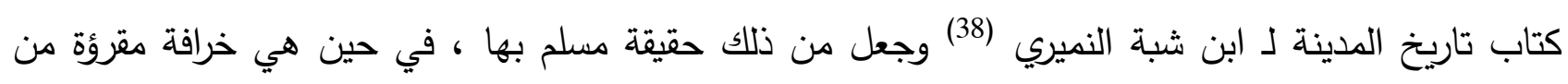

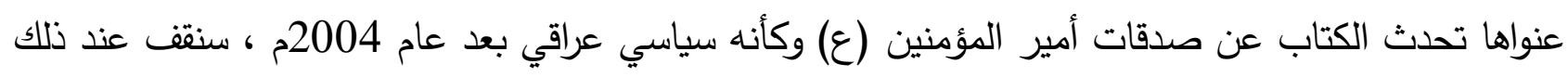

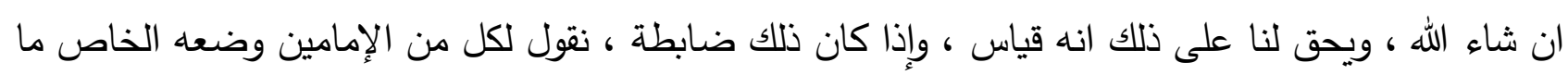

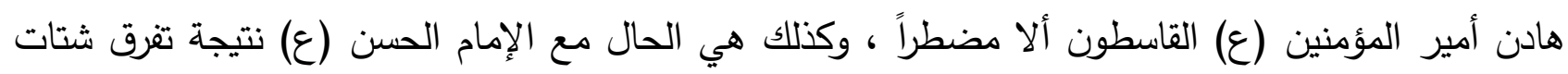


أما السند فيه ، أبو عيسى ، موسى بن عبد الرحمن بن سعيد بن مسروق الكندي ، كتب عنه أبو حاتم

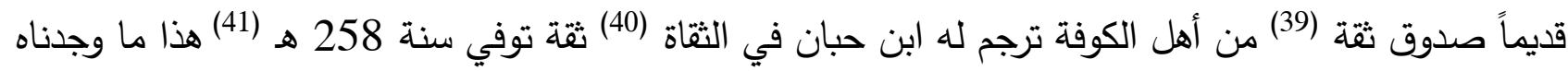

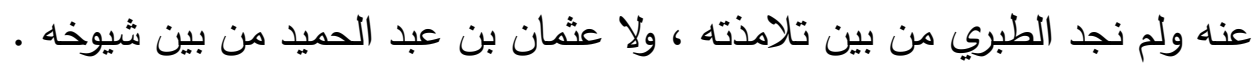

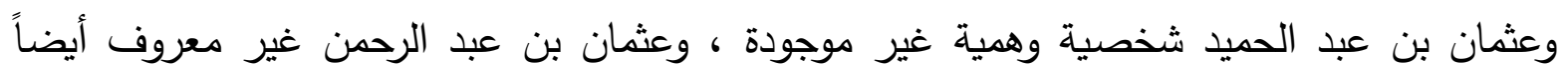
وقفنا عنده في الرواية التالية . وكذلك إسماعيل بن راشد السلهي ، قيل هو إسماعيل بن أبي إسماعيل ، يعد في الكوفيين ذكره ابن أبي

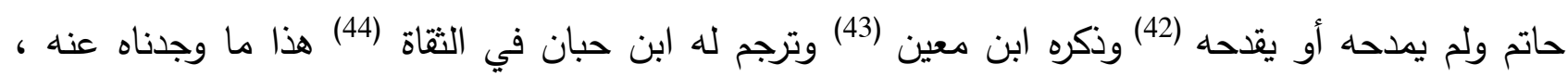

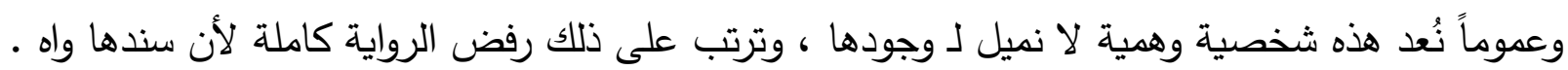

وروى المسروقي عن عثمان بن عبد الرحمن ، وزاد فيه كتب الإمام الحسن (ع) إلى معاوية في الصلح

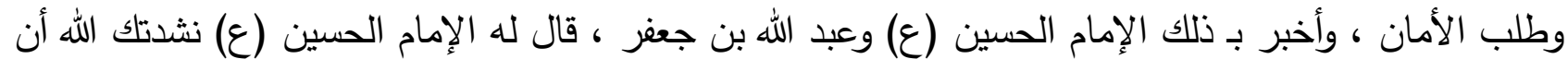

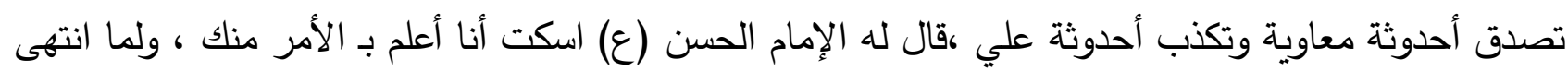

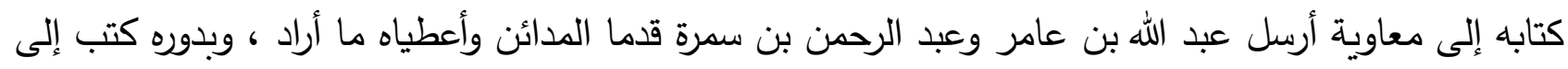

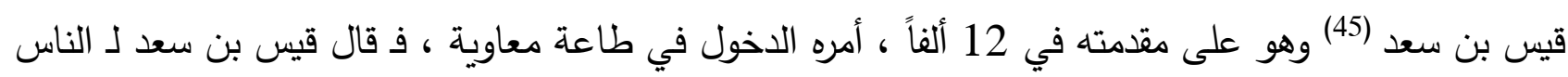

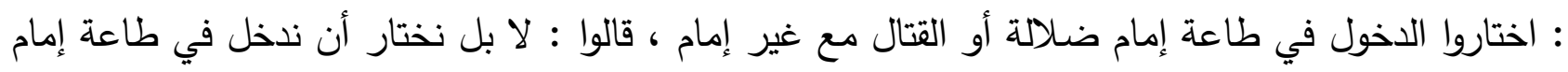

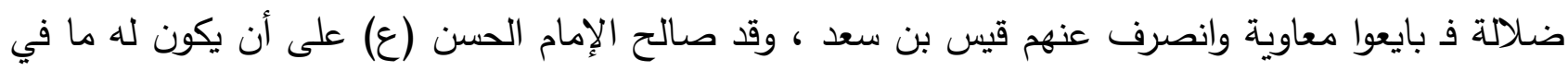

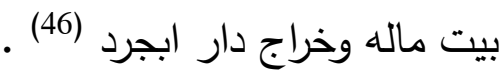
نسجل على الرواية جملة ملاحظات منها ، فردية الإمام الحسن (ع) في قراره ، ولم يسمع رأي أخيه ،

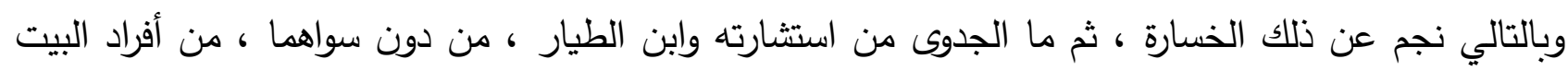

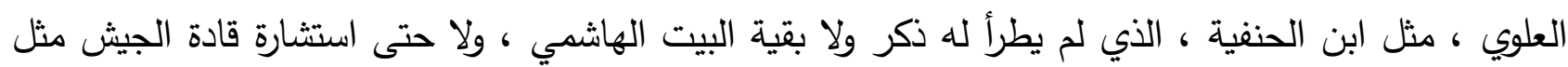

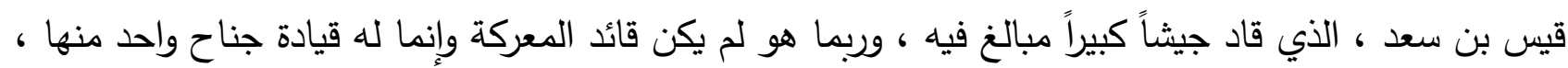

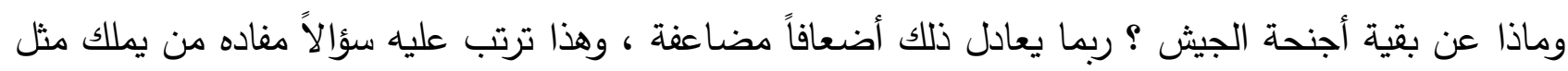

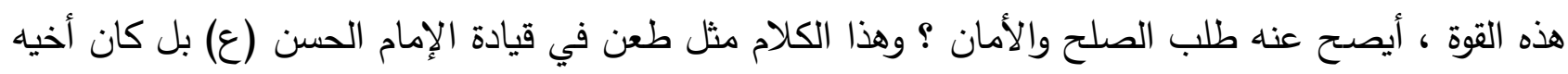

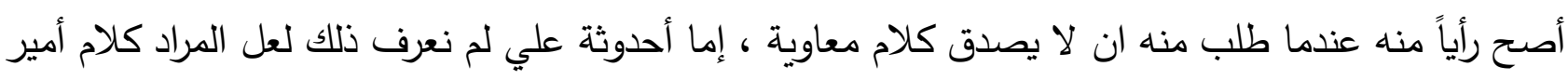

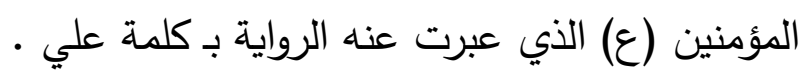

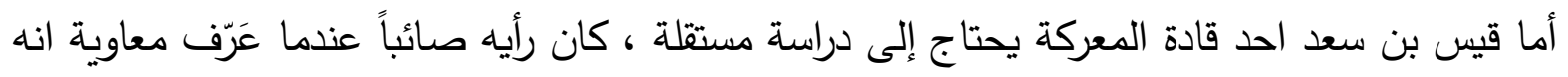

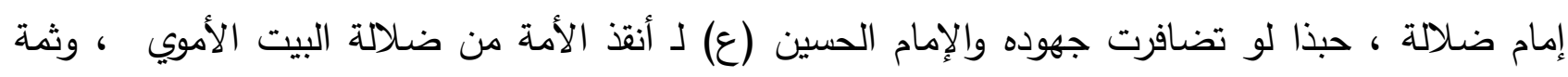

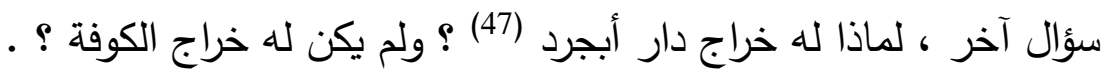


والسند فيه عثمان بن عبد الرحمن غير معروف لدينا لـ وجود أكثر من شخص بـ هذا الاسم ، درسناهم

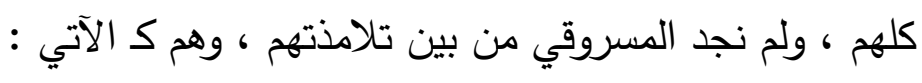

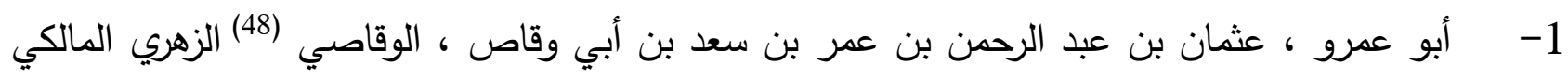

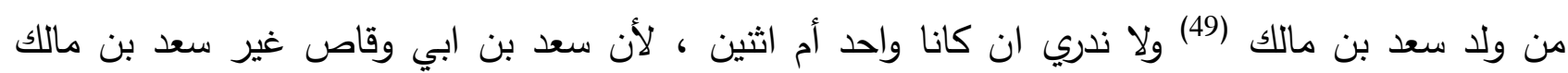

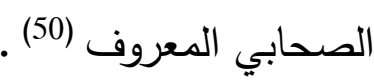

وإذا كان جده سعد بن أبي وقاص ينافي روايته عن عمته عائشة بنت سعد ، وبهذا لم تكن عمته ، وإنما

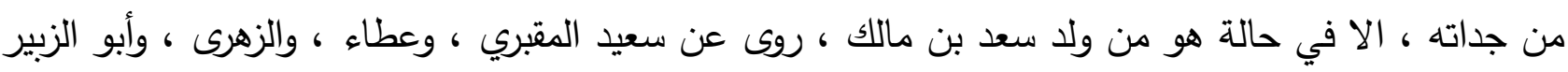

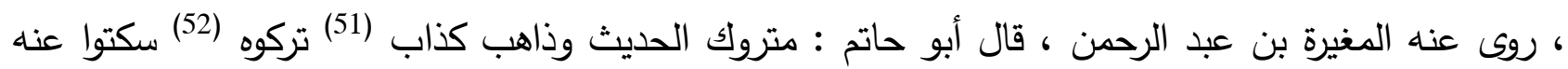

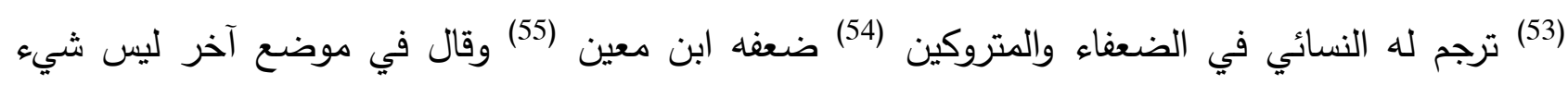

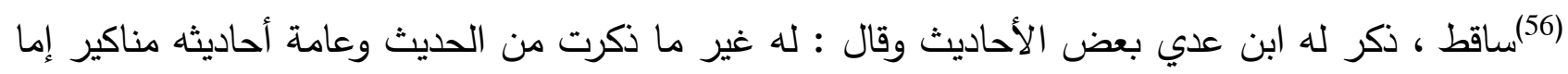

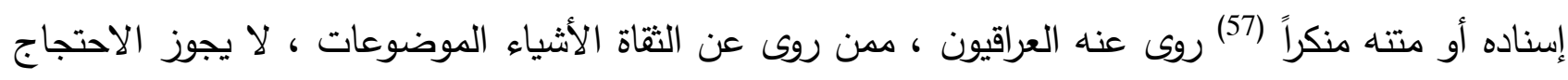
به (58) .

2- - أبو عبد الرحمن ، عثمان بن عبد الرحمن القرشي ، المكتب الطرائفي (59 سمع أحاديث طرائف ف سمي

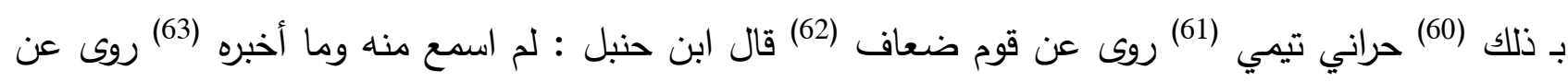

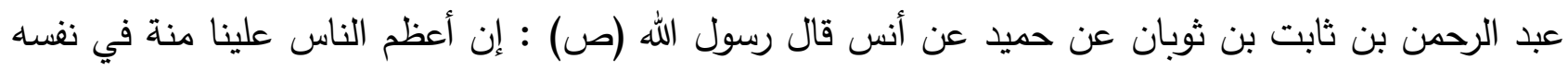

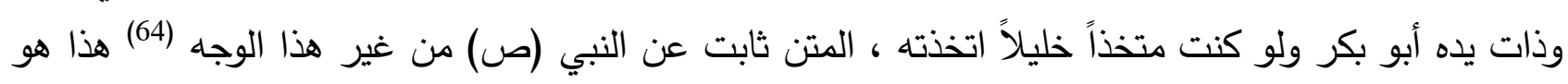

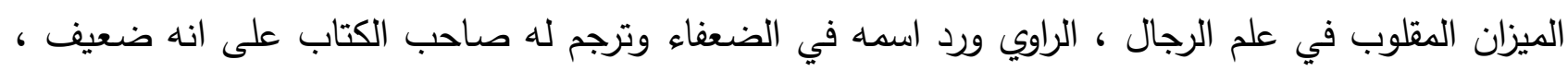

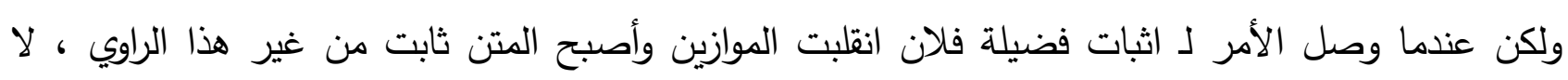

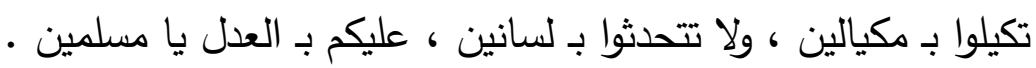

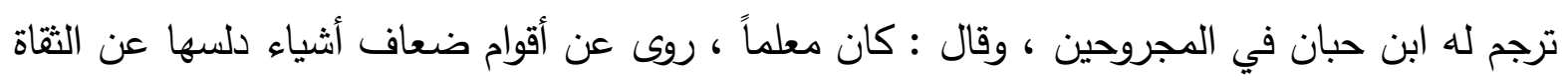

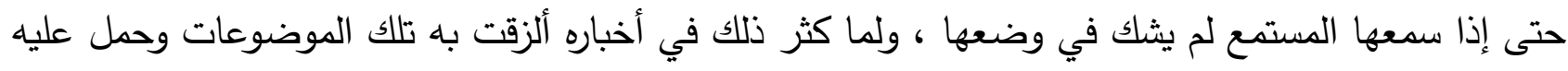

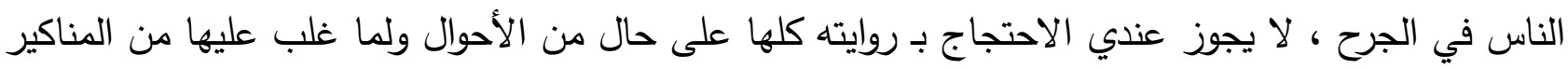

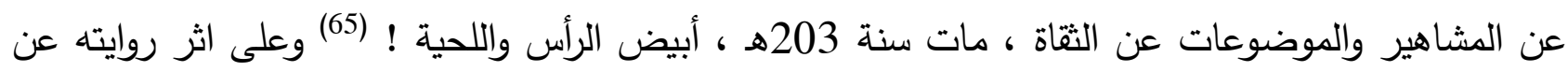
القوم الضعفاء ، ودلس عنهم ، قيل عنه مدلس (66) . وثقه أبن معين ، وقال أبو حاتم : صدوق وأنكر على البخاري إدخال اسمه في كتاب الضعفاء ، وقال

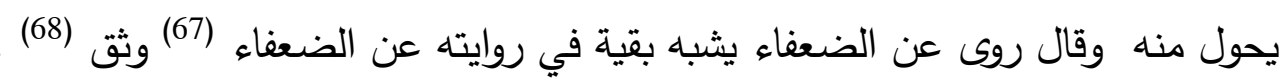

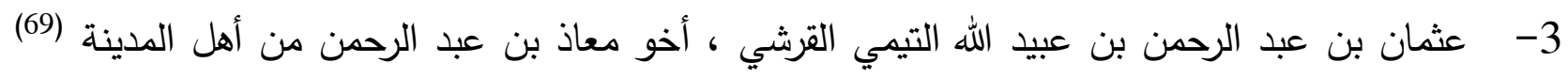

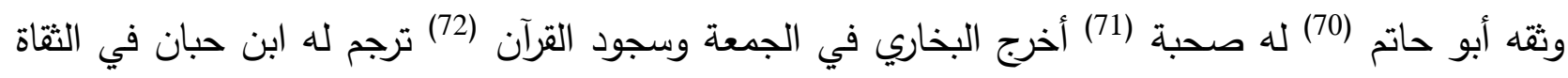


4 - عثمان بن عبد الرحمن بن ابان بن عثمان القرشي الأموي (74) ضعيف الحديث (75) .

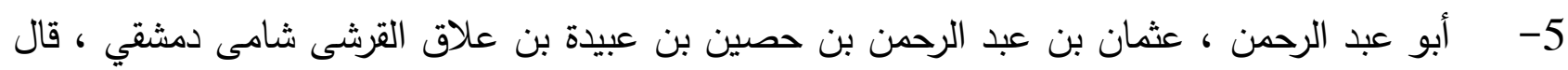

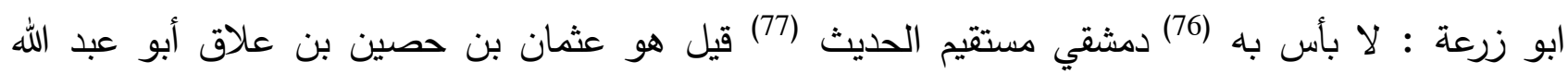

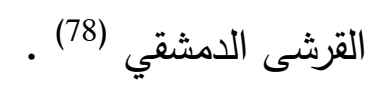

6 - عثمان بن عبد الرحمن بن سعيد بن يربوع القرشى مخزومي حجازي (79) . 8 - أبو عمرو (80) عثمان بن عبد الرحمن الجمحي البصري ، ليس قوي يكتب حديثه ولا يحتج به بـ (81) منكر الحديث ، روى عن عطاء بن أبي رباح عن ابن عباس قول رسول الله (ص) اللهم علم معاوية الكتابة والحساب وقه العذاب (82) قال أبو حاتم : لا يحتج به ، مات بات 184 هـ (83) وقفنا عند الحديث ولم تثبت صحته

9- أبو عبد الله ، عثمان بن عبد الرحمن بن عبد الله بن موهب مولى آل الحكم بن أبي العاص روى إلى

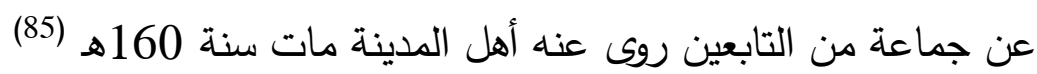

\section{ملخص شرط المال في الروايات السابقة}

\section{Summary of condition of money in previous narrations}

بعد أن درسنا الروايات القائلة بوجود مال في الهدنة لم نجدها متفقة على عينة معينة ومبلغ ثابت كل

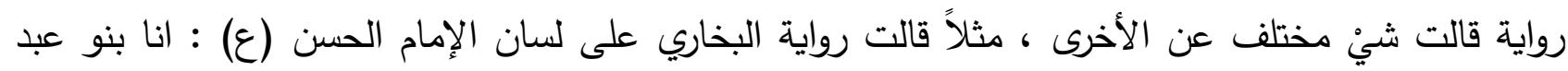

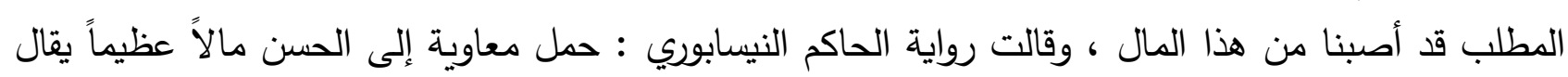
500 إلف إلف درهم (86) . وعلى رواية اشترط الإمام الحسن (ع) ان يكون له خراج الأحواز كل عام ، ول الإمام الحسين (ع) ألفي

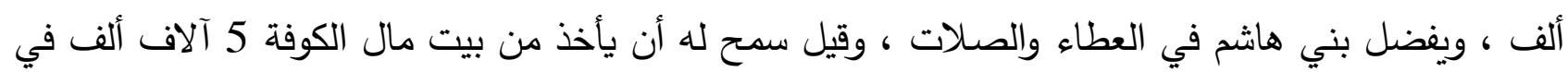

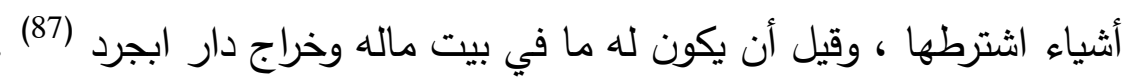

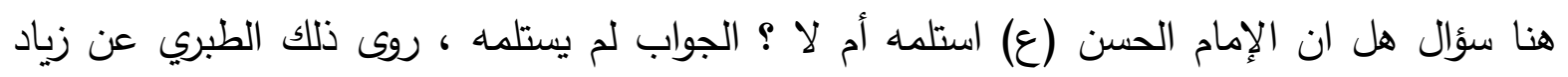

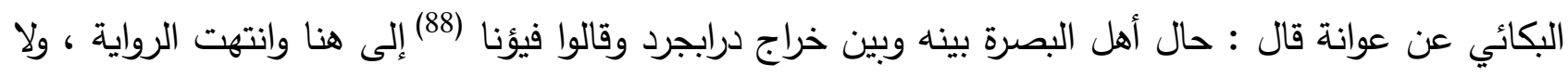

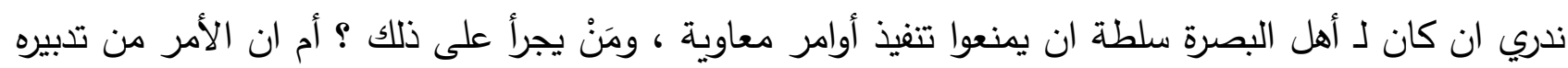
ومكره .

وهناك مَنْ أكمل الرواية على لسان أهل البصرة قالوا : لا نعطيه أحدا وكان منعهم بـ أمر معاوية (89)

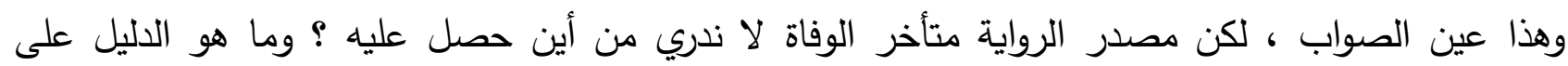

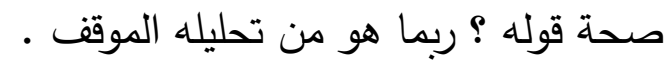




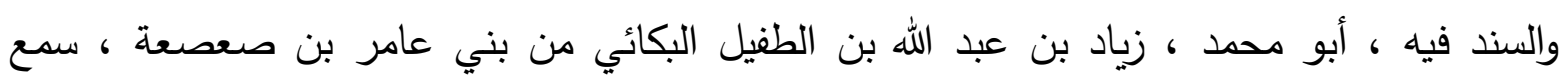

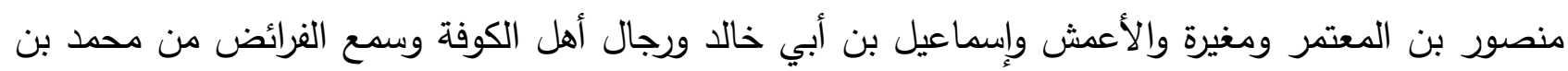

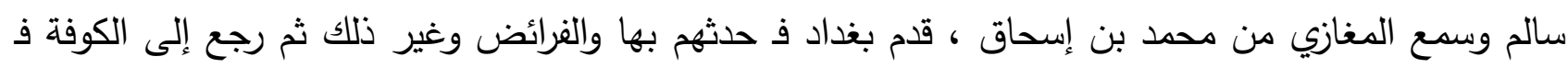

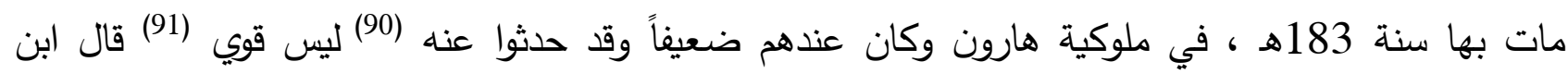

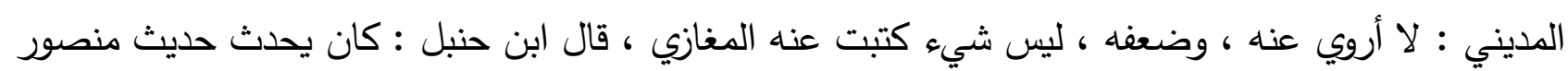

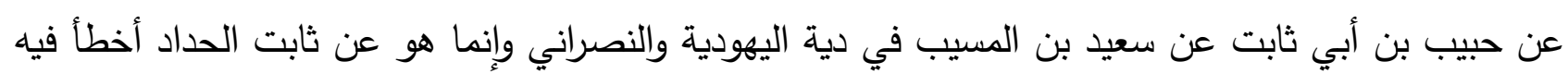

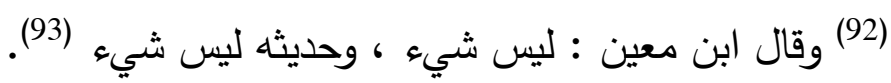

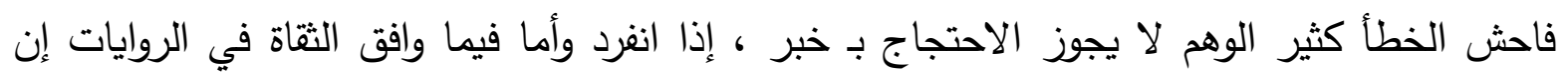

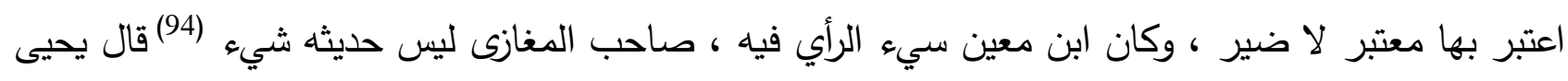

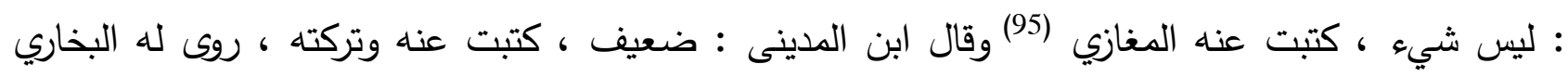

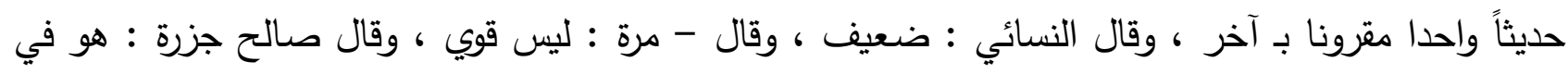

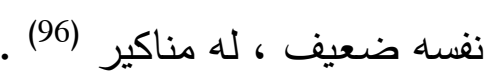

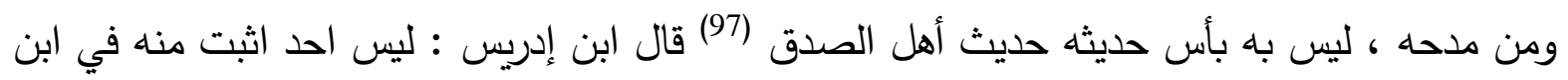

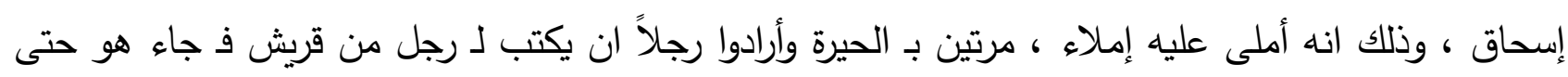

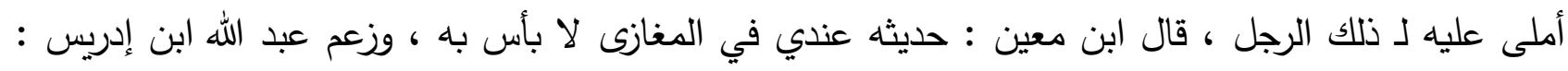

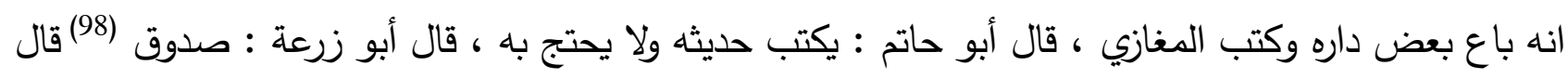
وكيع : هو أشرف من أن يُكنب (99).

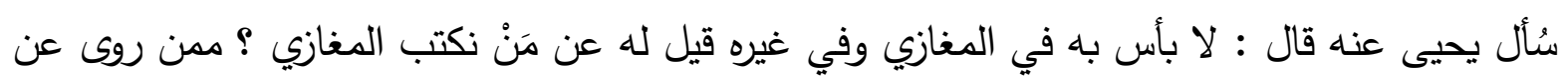

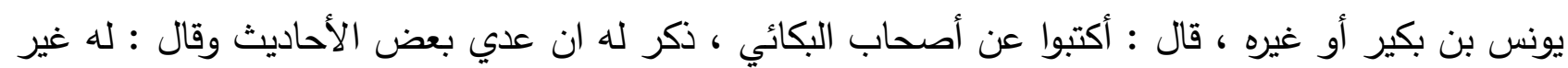

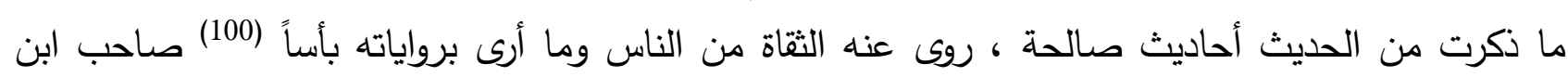
إسحاق ، وقال صالح جزرة : هو من أثبتهم في المغازى (101) .

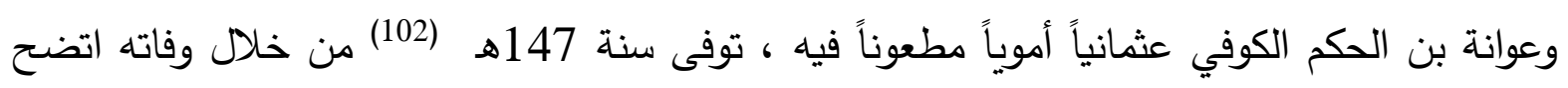
انه لم يدرك الأحداث التي بين الإمام الحسن (ع) ومعاوية .

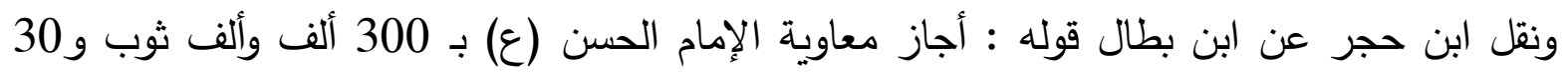

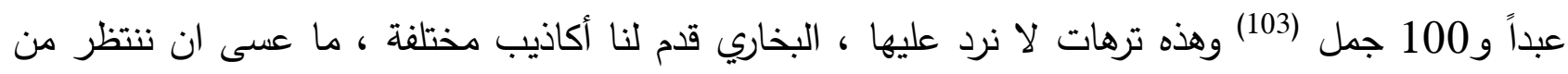

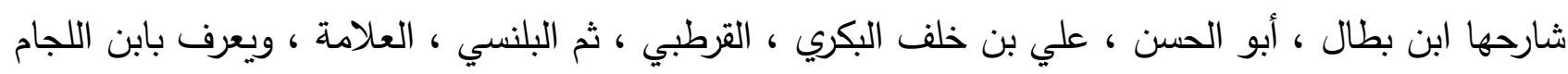

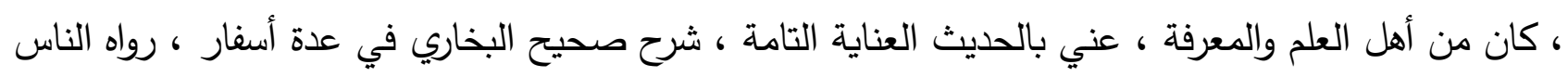

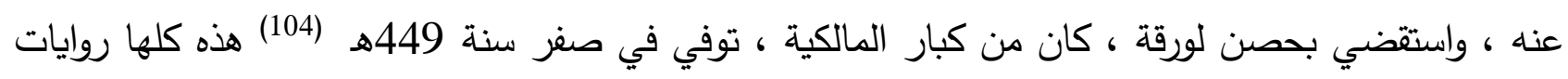

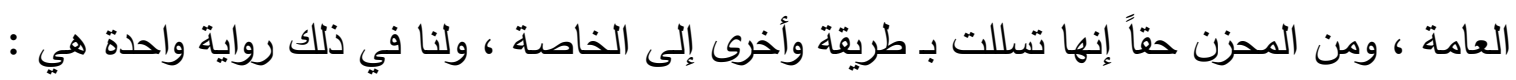




\section{رواية الصدوق}

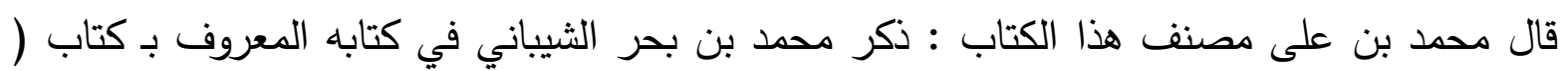

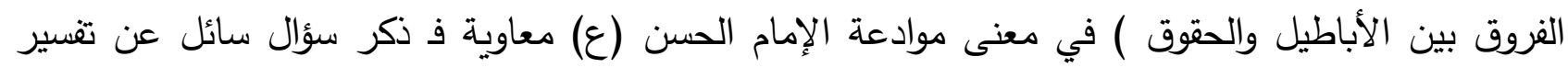

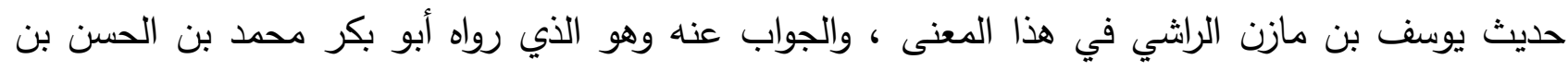

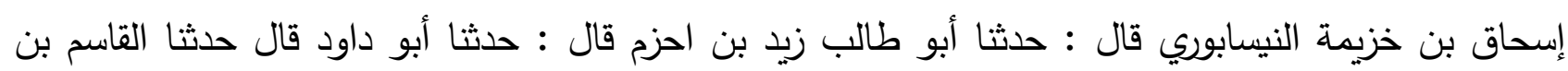

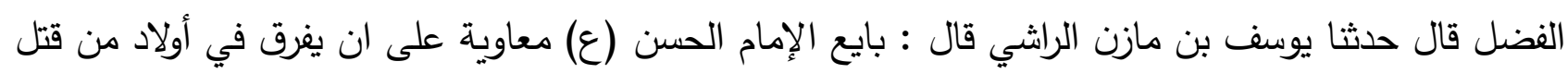

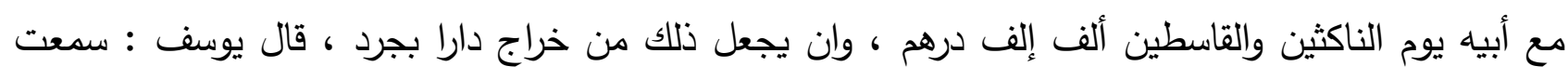

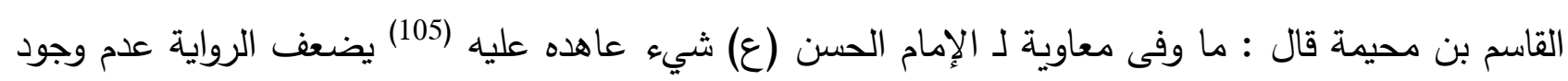

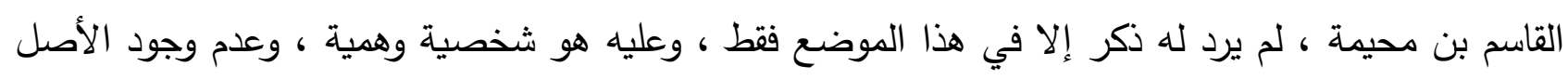

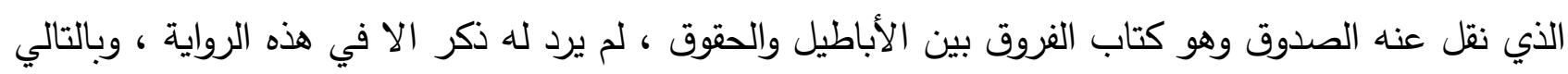
نتحدث عن أصل مفقود .

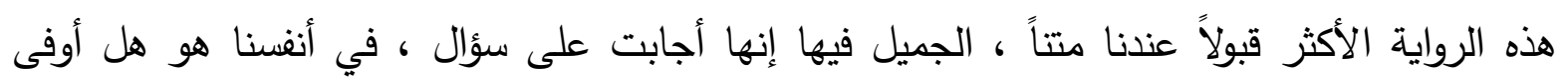

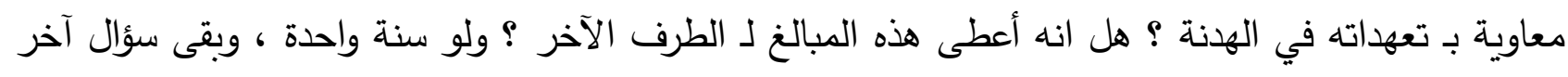

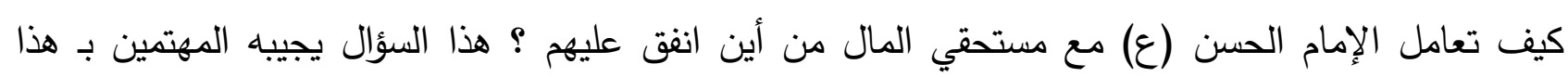

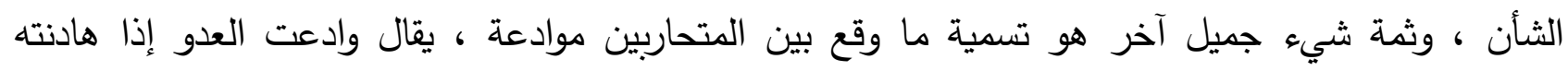

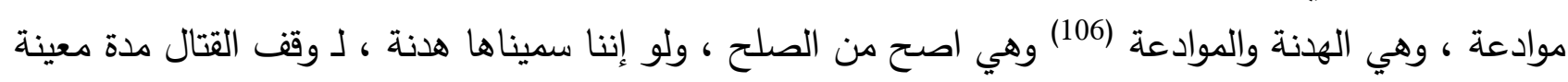

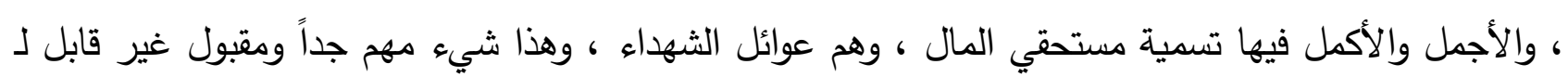

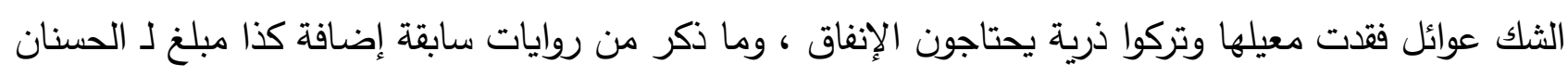

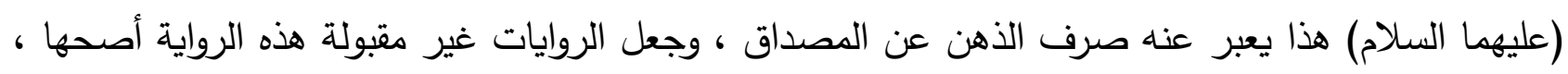

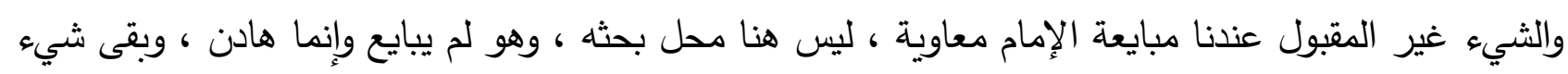

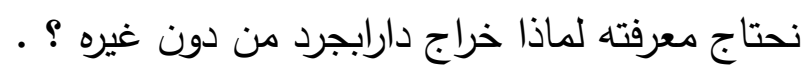

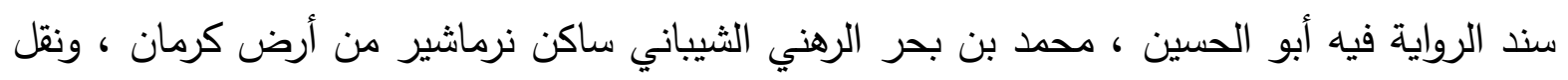

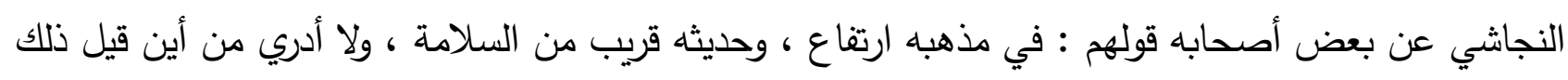

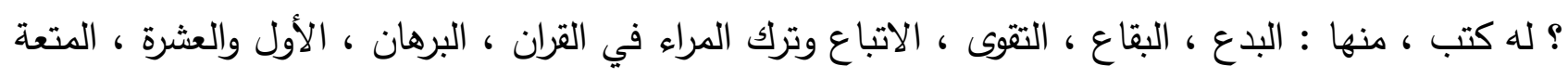

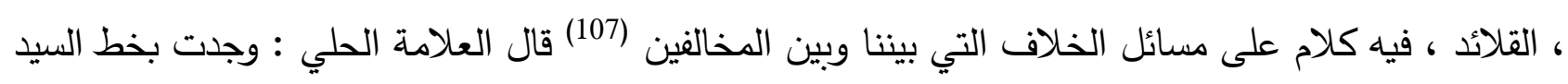

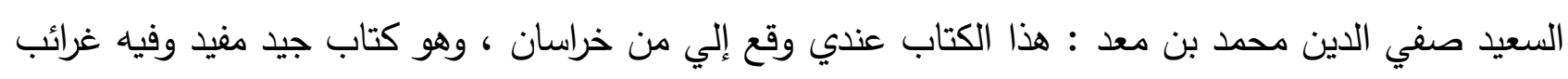

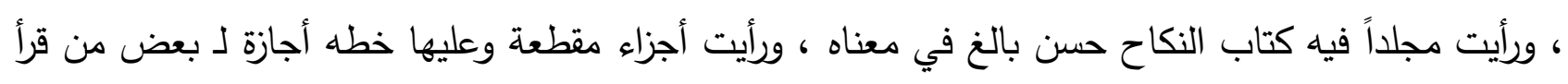

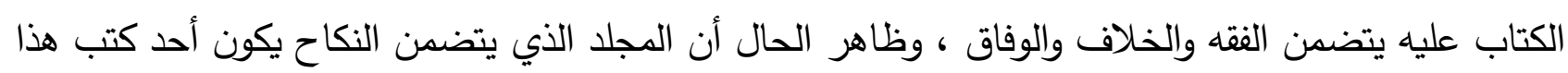

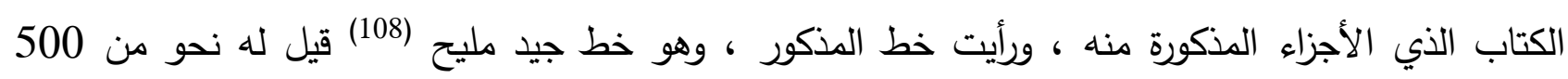


مصنف ورسالة ، وكتبه موجودة ، أكثرها بـ خراسان ، من كتبه ، الفرق بين الال والامة (109) والغريب أننا لم

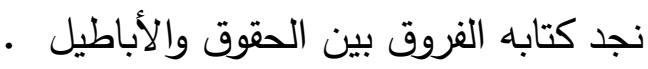

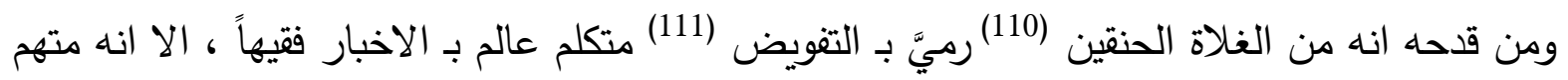
بالغلو (112) وقال ابن الغضائري : انه ضعيف ، في مذهبه ارتفاع ، والذي اراه التوقف في حديثه (113) .

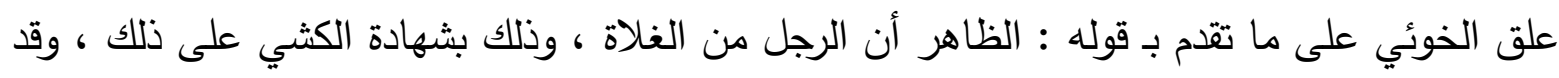

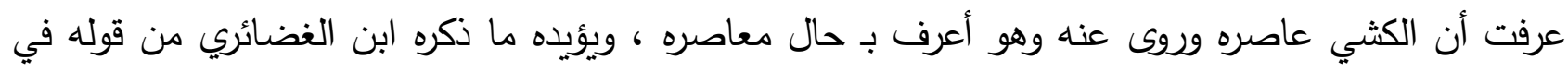

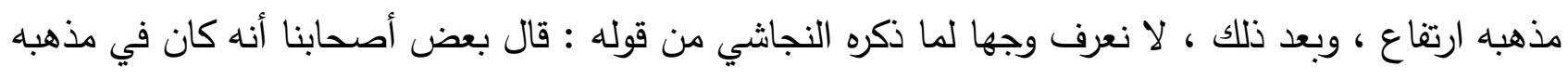

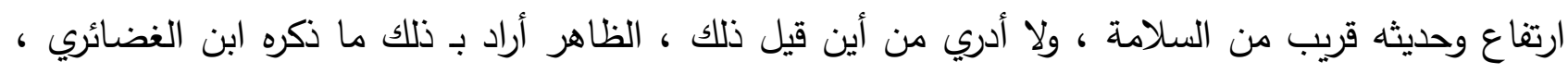

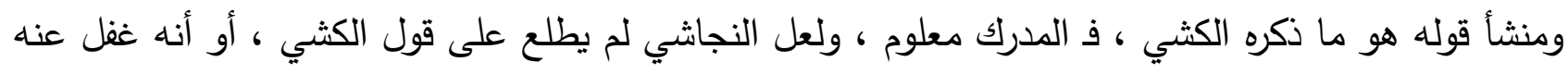

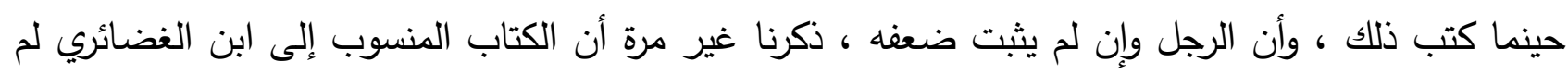

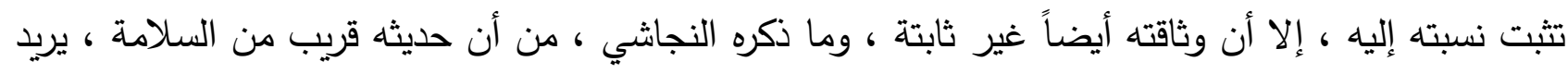

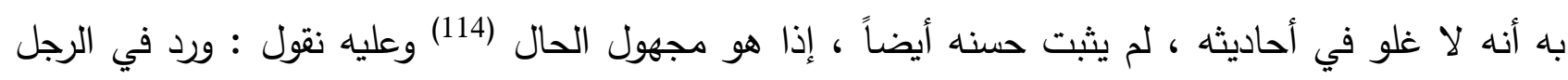

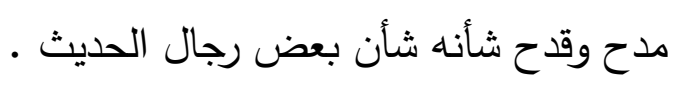

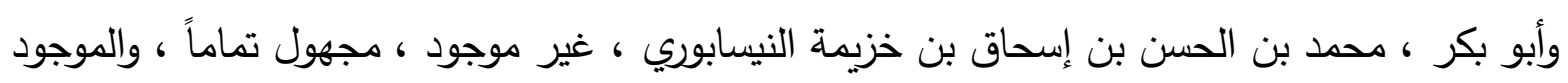

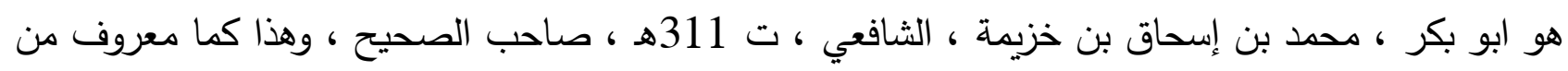

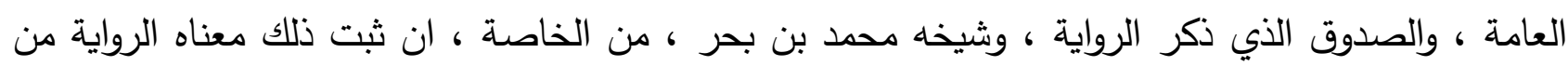

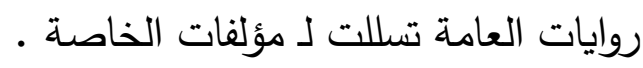

وأبو طالب ، زيد بن أخزم الطائي البصري روى عن أهل العراق ، حدث عنه ابن خزيمة وغيره مستقيم

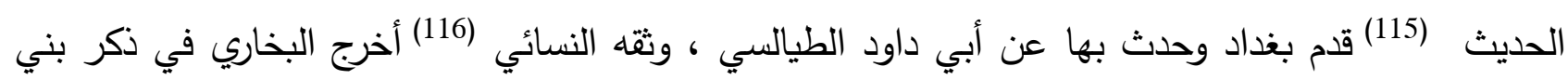

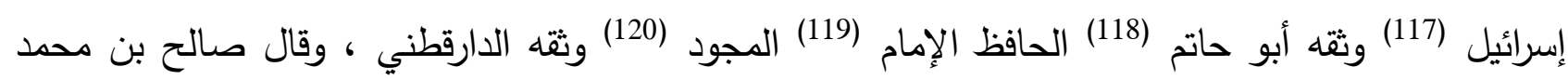
صدوق في الرواية (121) ثقة حافظ حاتم (122) مات بعد 250هـ (123) ذبحوه الزنج سنة 257هـ (124)

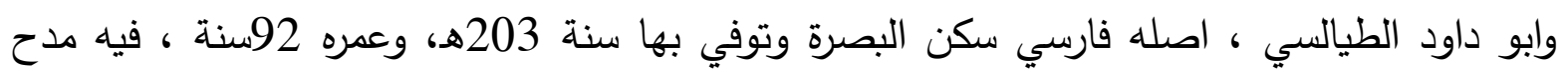
وقدح (125) . وأبو المغيرة ، القاسم بن الفضل بن معدان البصري الحداني ، لم يكن حدانياً كان نازلاً فيهم هو ازدي

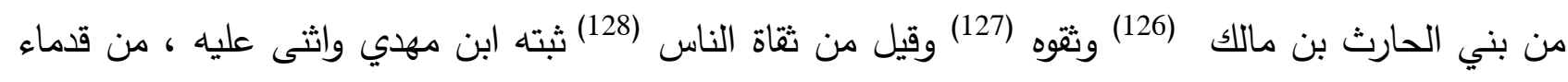

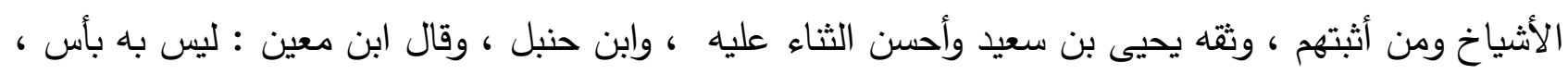

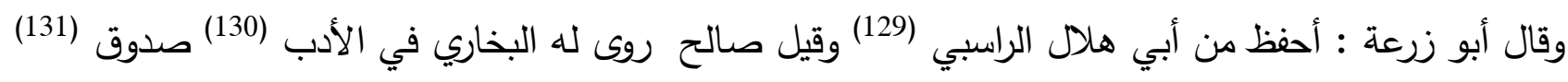


ومن قدحه : قيل لـ يحيى بن سعيد : ثبته ابن مهدي ، قال : ذالك منكر (132) صاحب حديث ، قال

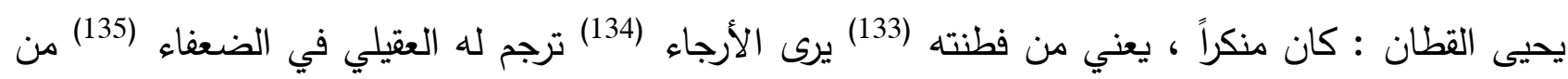

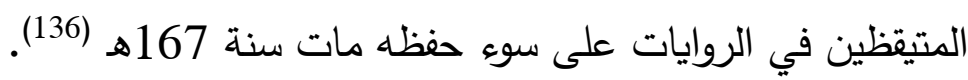

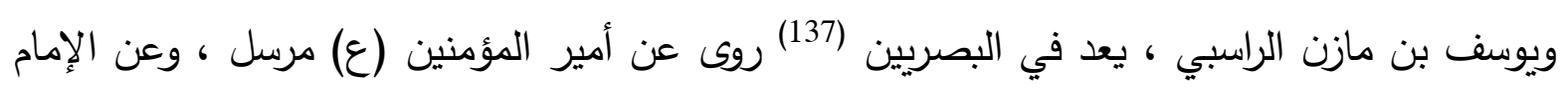

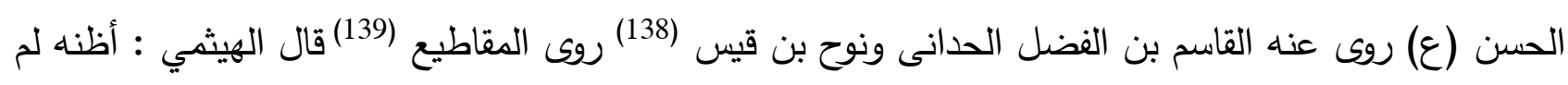

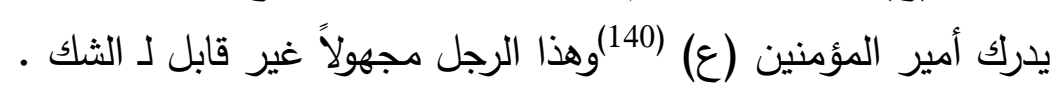

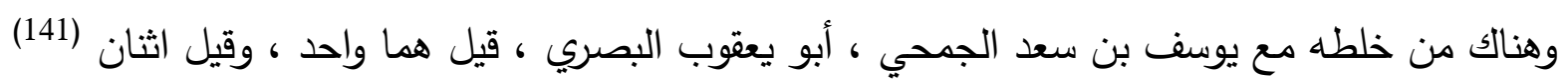

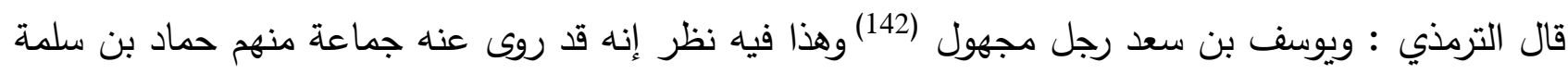

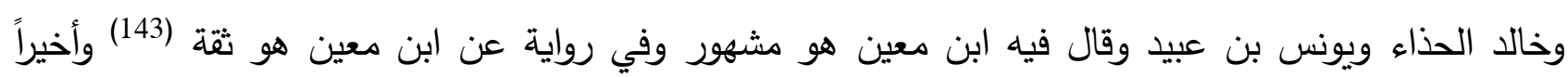

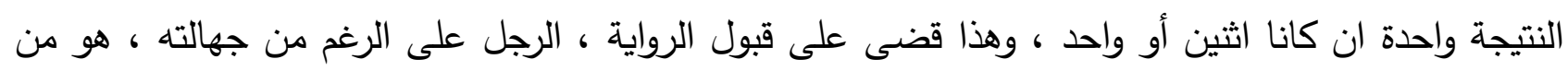

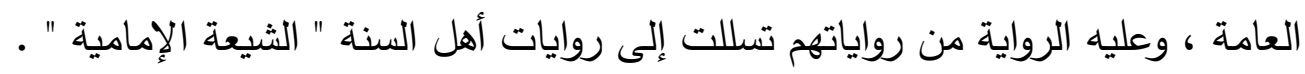
موقف راضي آل ياسين من الروايات السابقة

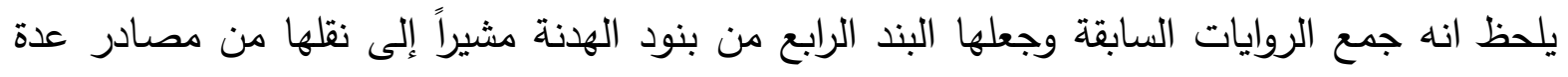

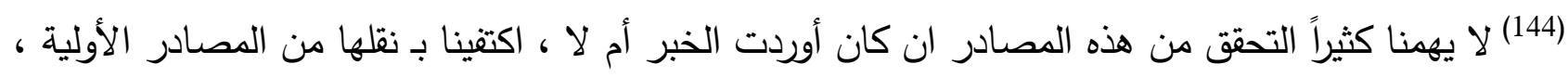

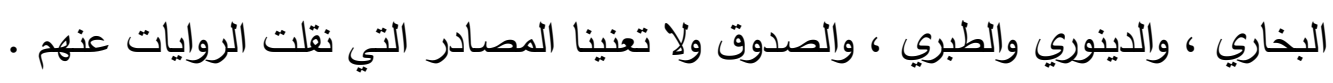

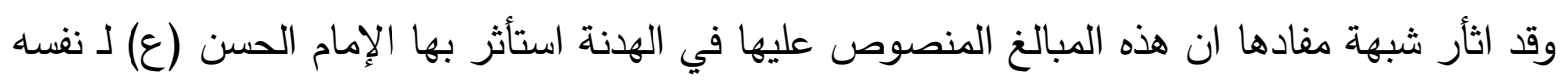

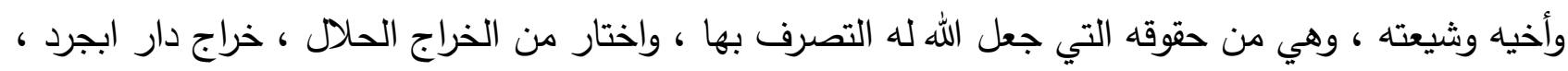

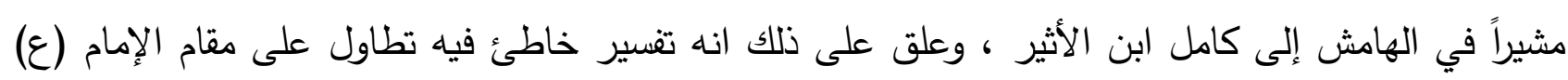

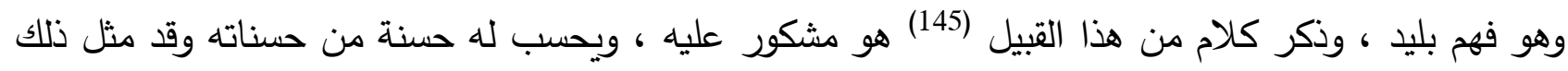

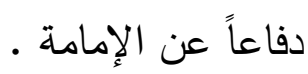

\section{صدقات أمير المؤمنين (ع) (عام)}

من الأمور التي اعتمدها سامي البدري على رفض وجود شرط المال في هدنة الإمام الحسن (ع) هذه أهن

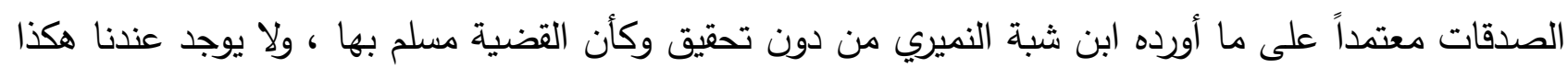

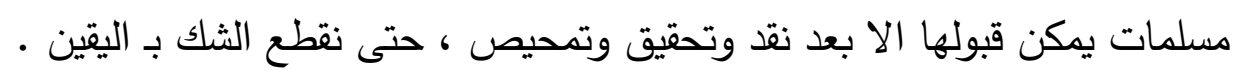

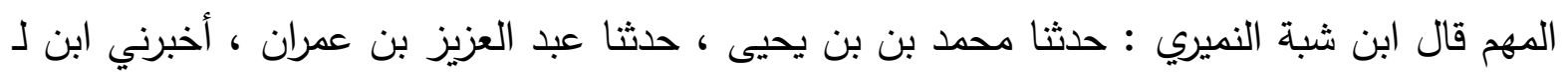

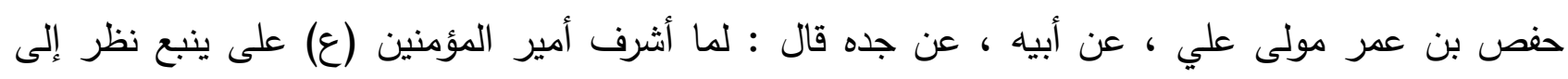

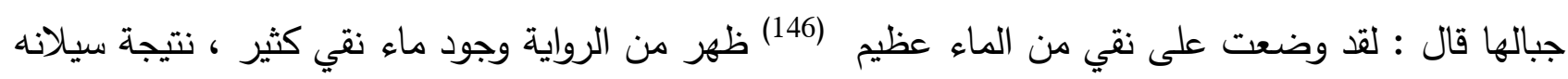

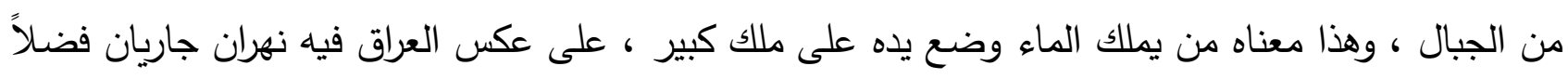

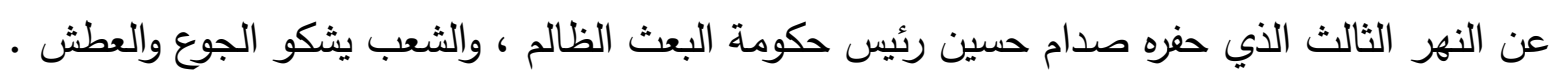


وعليه لا بد معرفة ينبع ، تقع عن يمين رضوى (147) لـ من كان منحدراً من المدينة إلى البحر على ليلة

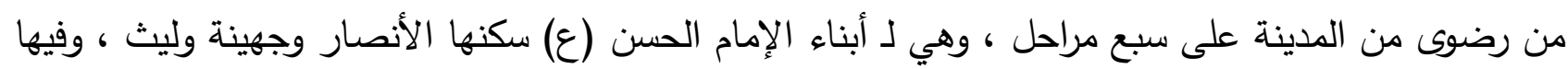

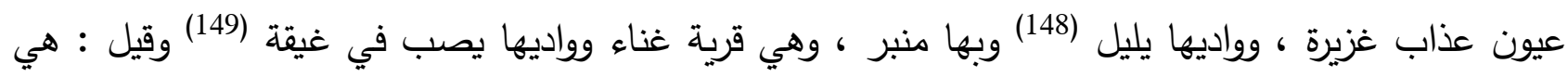

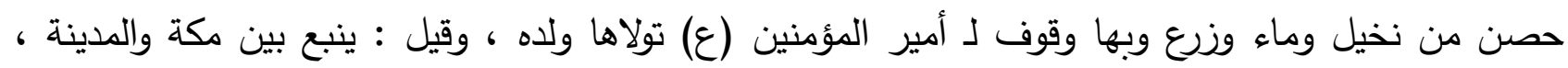

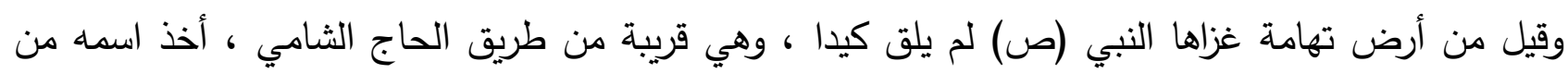

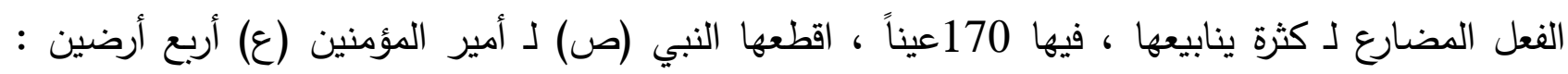

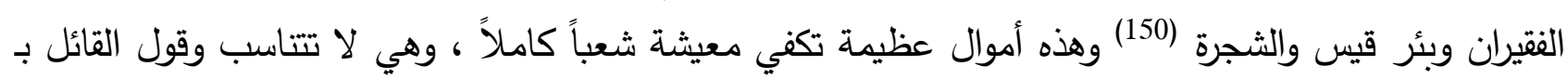

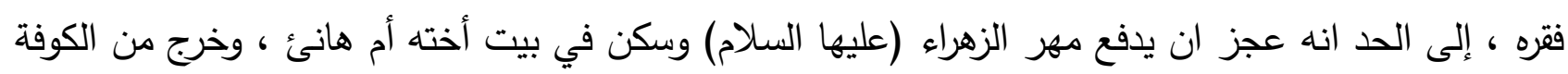
في القطيفة التي أتى بها من المدينة (151) ما يملكه أراض واسعة التهاء حتى صيها السلام) وسكن فيروه أقطاعي كبير والعياذ بـ الله .

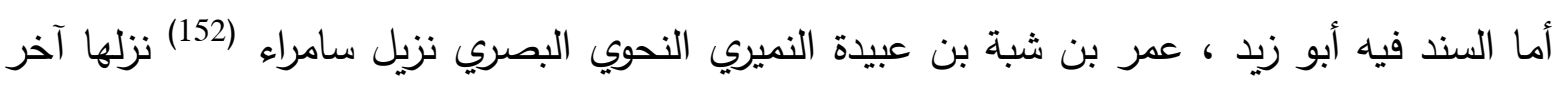

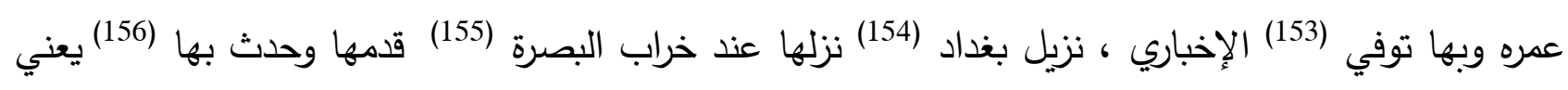

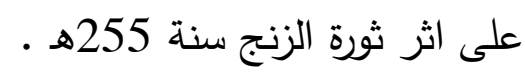

اسم أبيه زيد ولقبه شبة لأن أمه كانت ترقصه وتثقول يا بأبي وشبا وعاش حتى دبا شيخا كبيراً خبا (157)

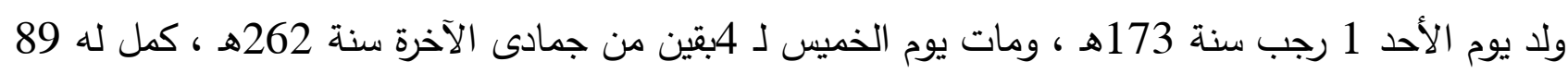

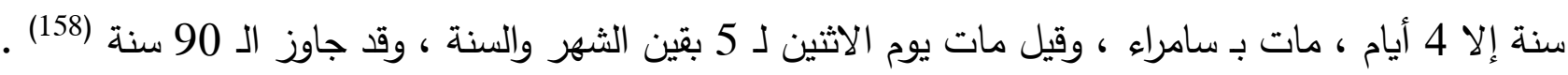

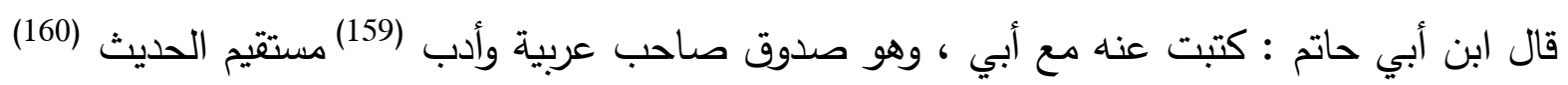

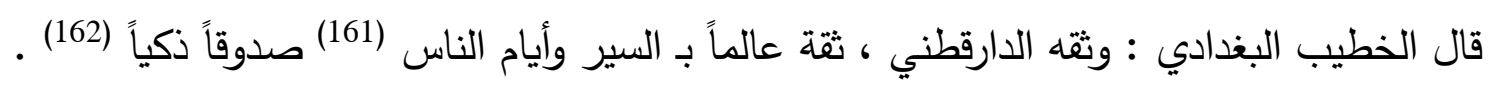

هو القائل : قدم وكيع بن الجراح عبادان ف منُعت من الخروج إليه لـ حداثتي فـ رأيته في النوم يتوضأ

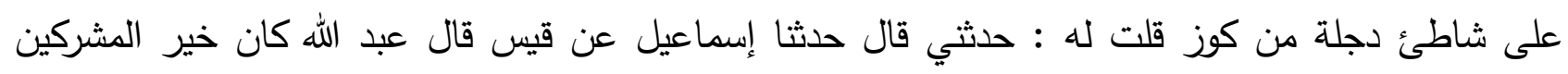

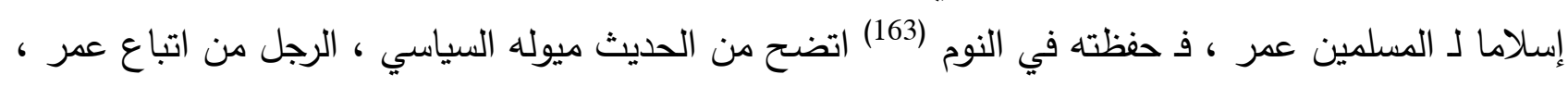

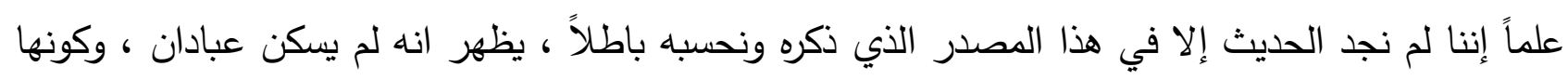

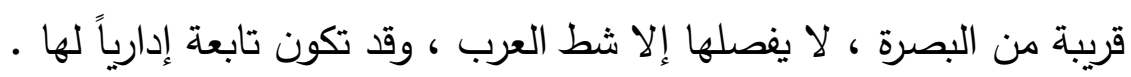

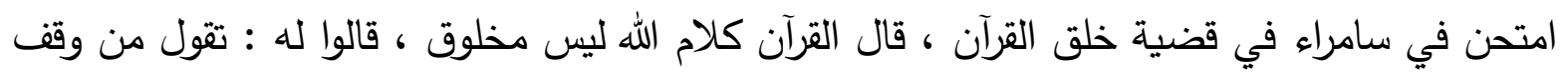

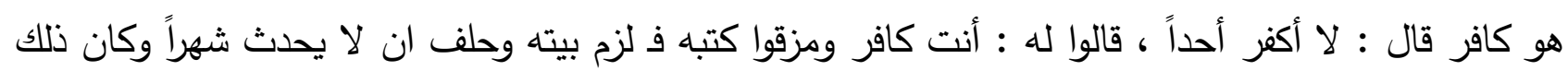
حدثان قدومه من بغداد بعد الفتنة ، أنثد قصيدة في محنته خاطب بها النبي (ص) وابن أبن أبي قحافة سماه صدّيقاً

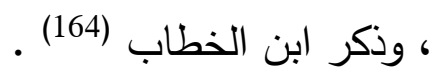




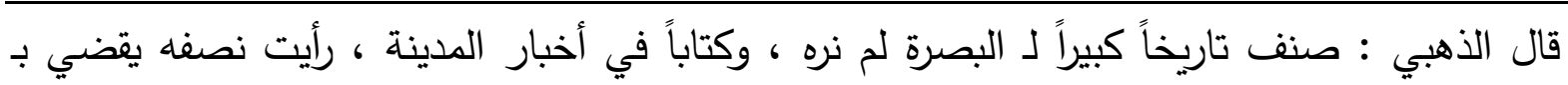

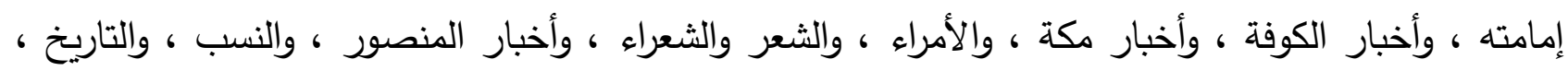
في أشياء كثيرة (165) .

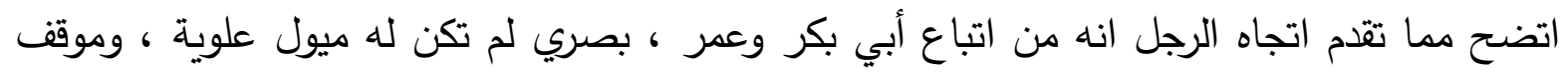

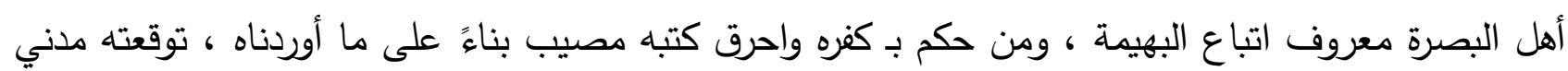

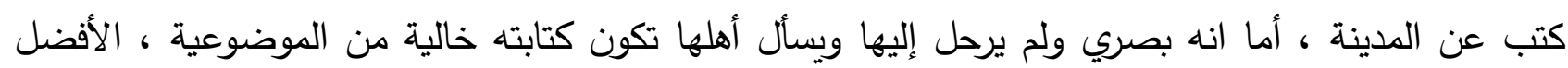

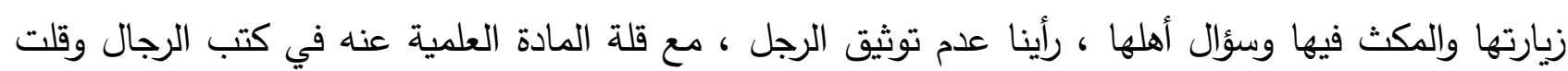
نقاده .

السند فيه ، أبو غسان ، محمد بن يحيى (166) اعتمد عليه ابن شبة النميري كثيراً في النقل ، ولن نجده في علم الرجال . وعبد العزيز بن عمران بن عبد العزيز ، أمه أمة الرحمن بنت حفص بن عمر بن عبد الرحمن بن الرهال

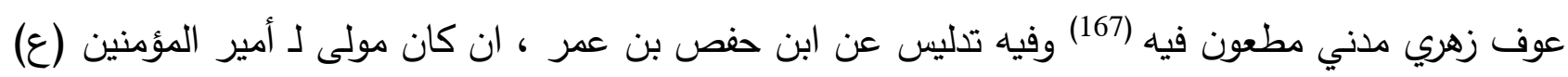
بـ هذا الاسم .

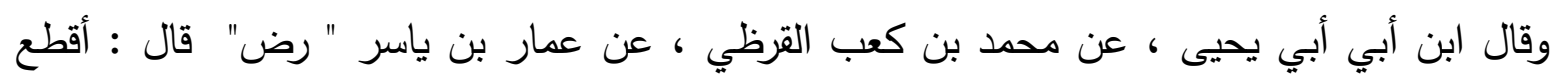

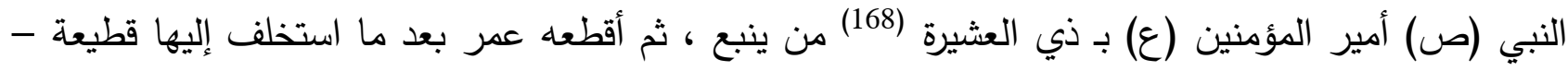

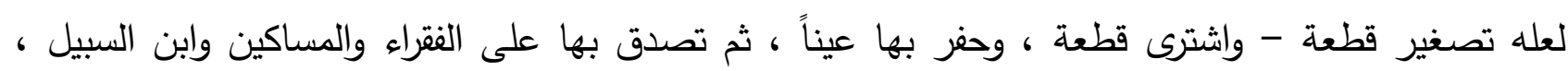

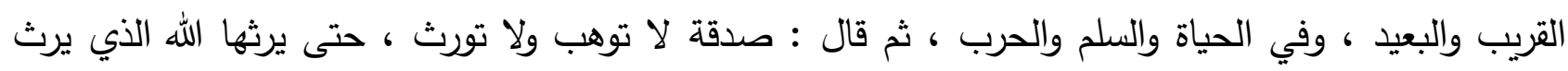

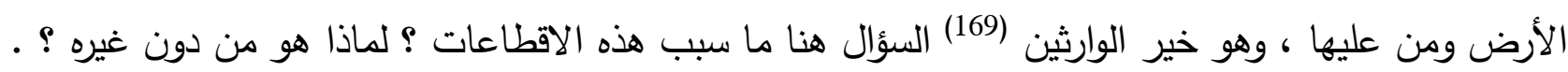

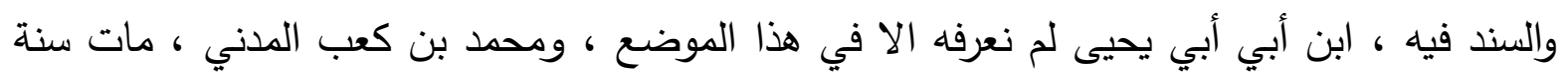

110ه، وقيل سنة 117هـ ، وقيل سنة 108هـ ، من العامة وثقوه ، لديه وهم وإرسال (170).

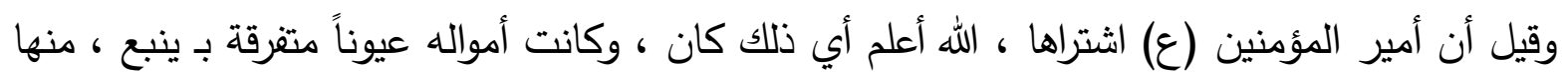

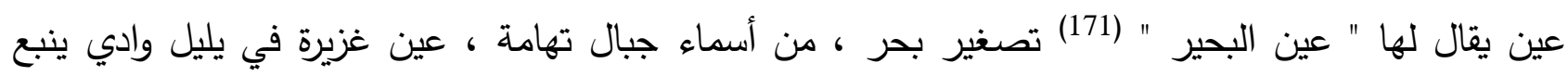

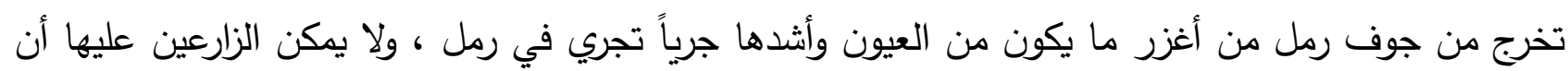

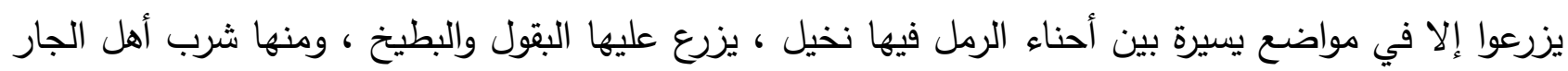

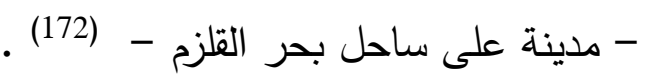
وعين يقال لها : عين أبي نيزر (173) كنية أحد موالي أمير المؤمنين (ع) نسبت إليه العين ، قيل أنه

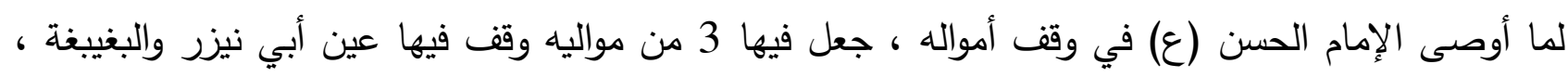

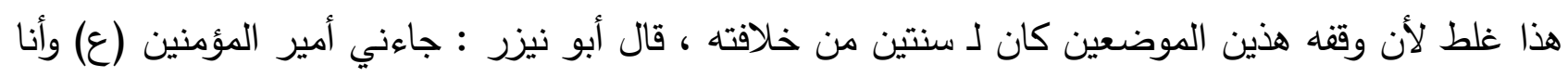

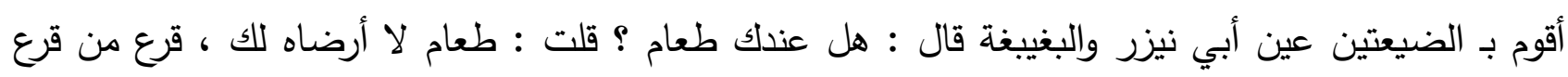


الضيعة صنعته بـ إهالة سنخة (174) قال : علي به ، فقام إلى الربيع - جدول - غسل يديه ثم أصاب من ذلك

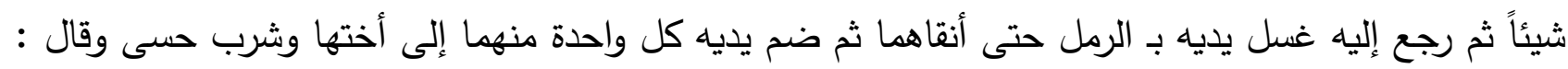

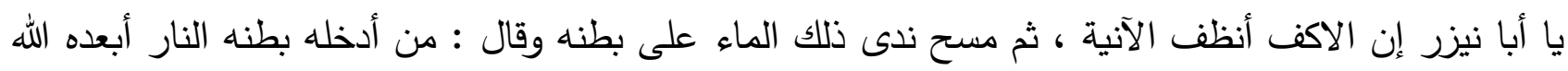

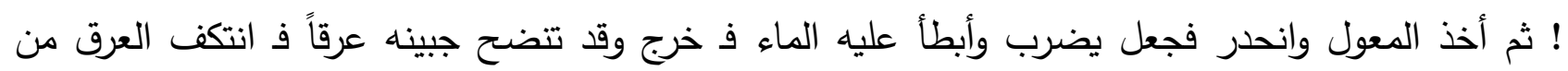

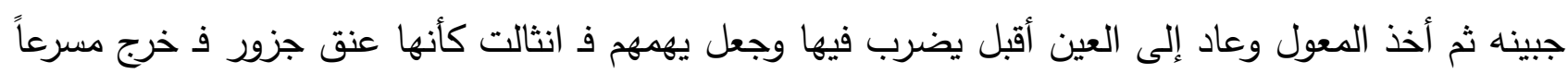

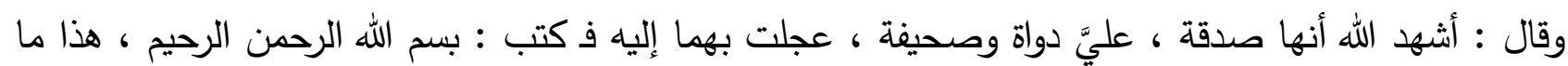

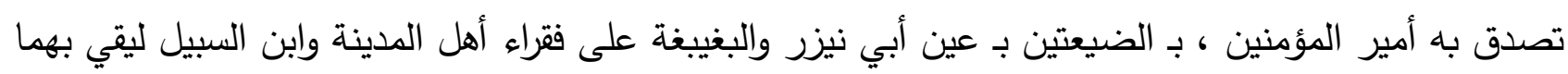

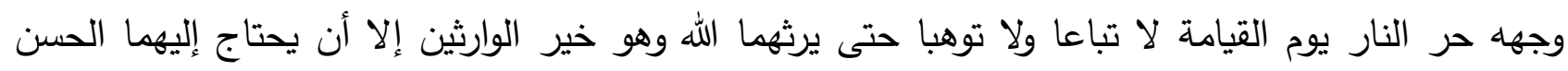

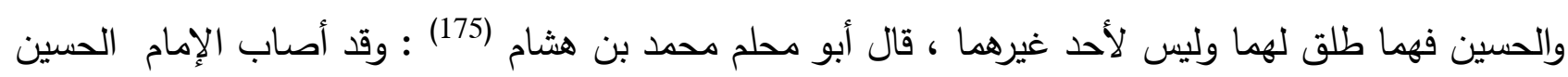

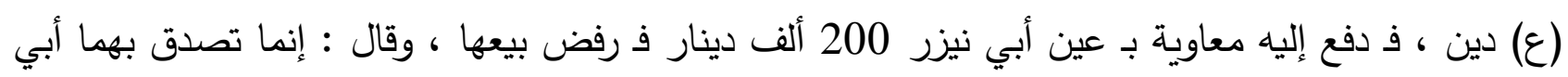

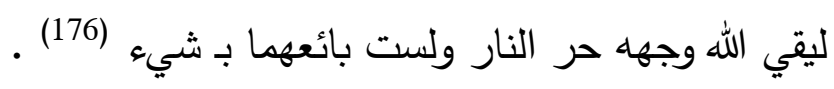

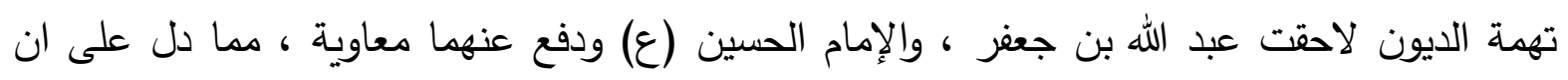

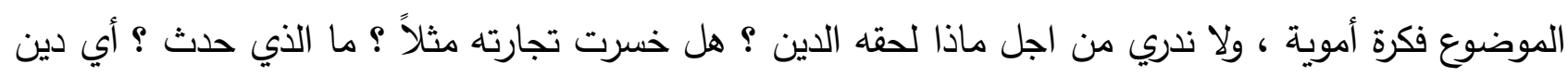

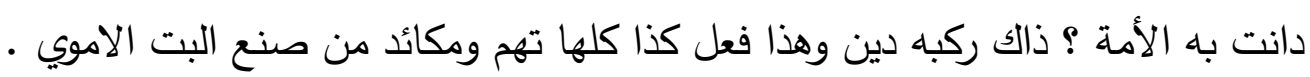

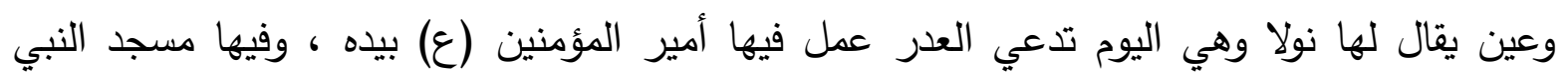

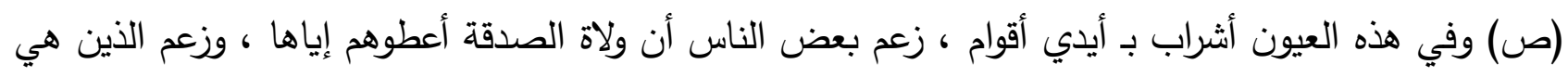

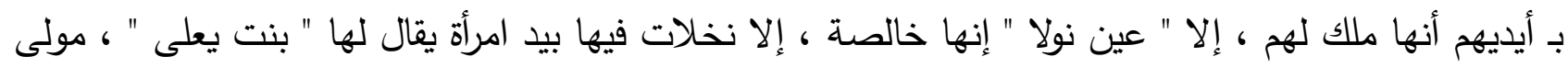

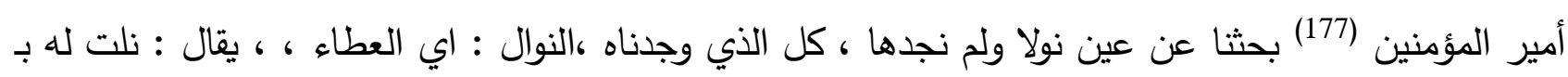

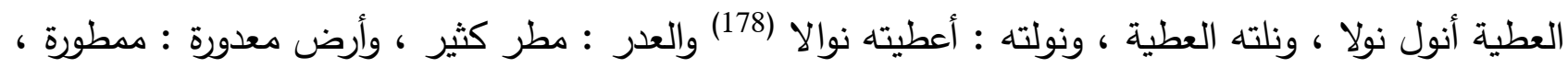

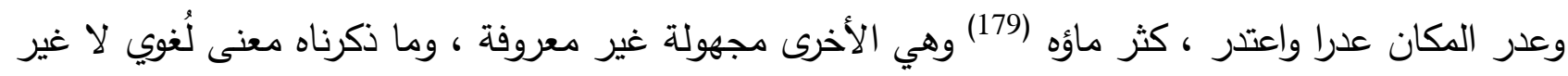

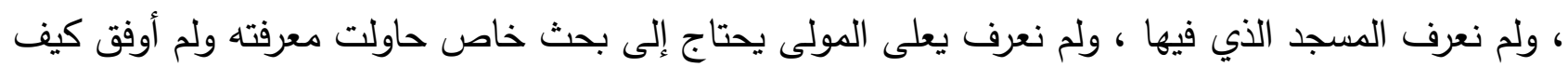

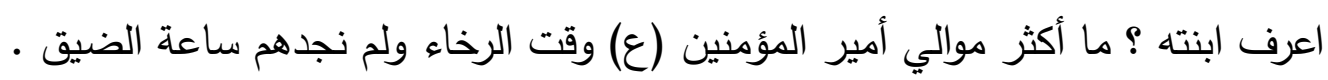

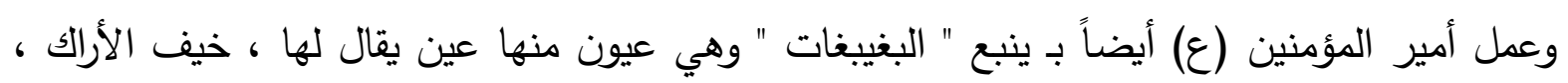

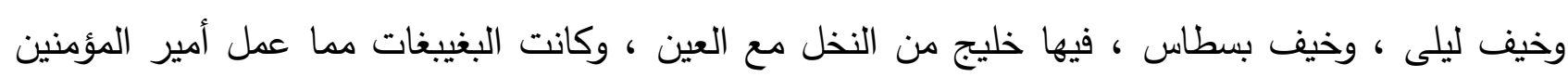

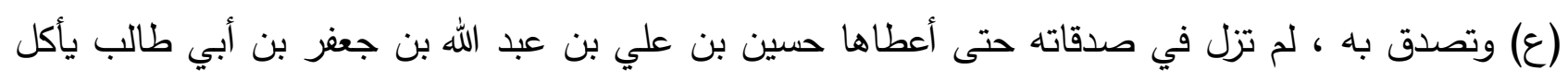

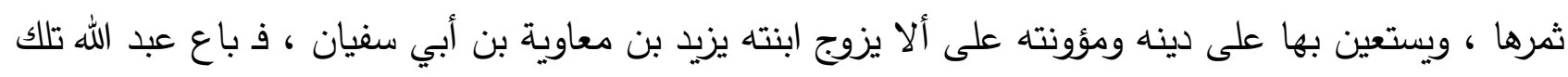

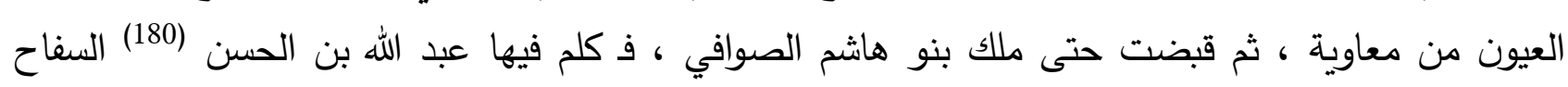

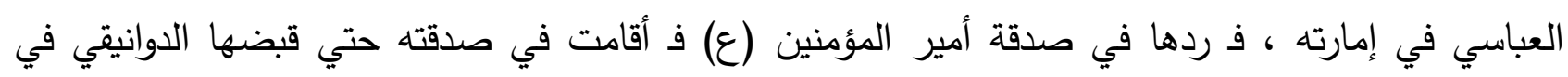

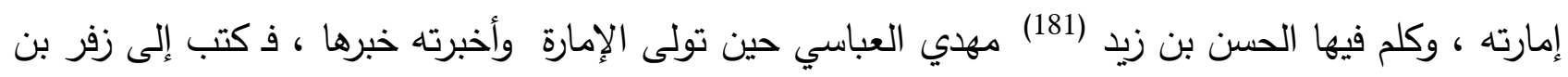




\section{هبلة أبحاث هيسان، المجلد السابع عشر، العدد الرابع والثلاثون، كانون الاول، السنة 2021}

https://doi.org/10.52834/jmr.v17i34.68

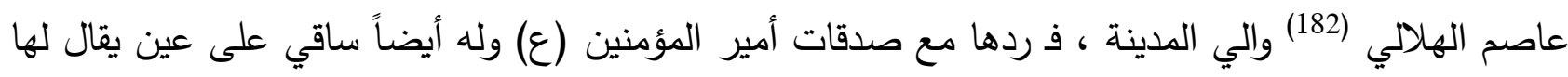

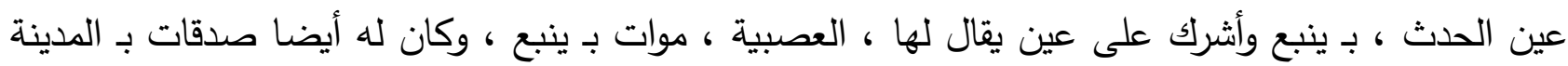

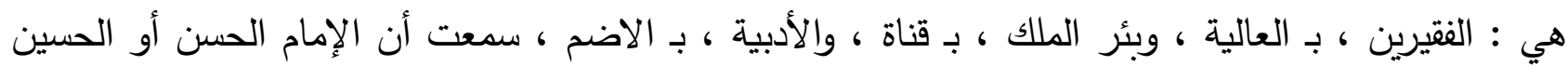

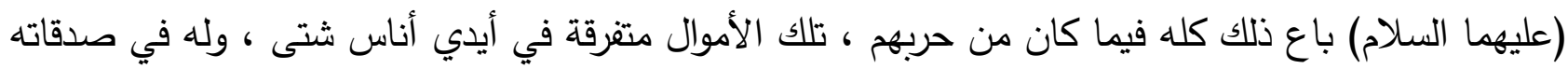

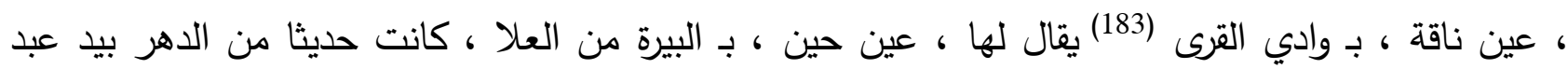

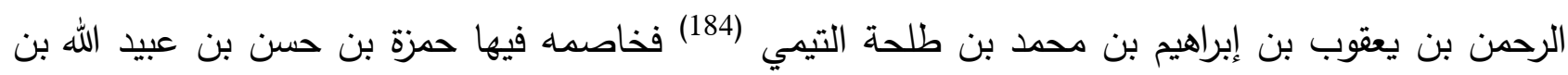

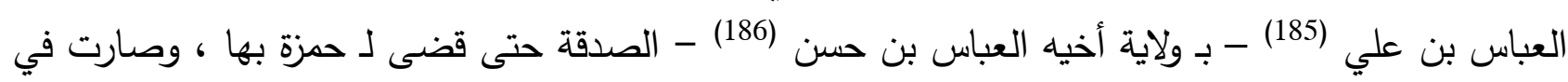

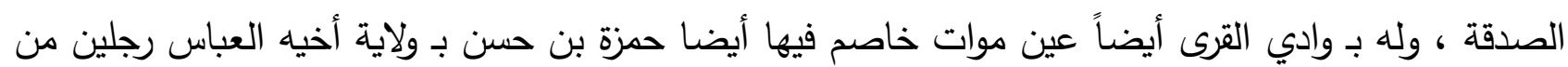

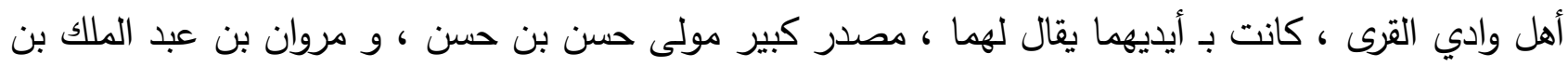

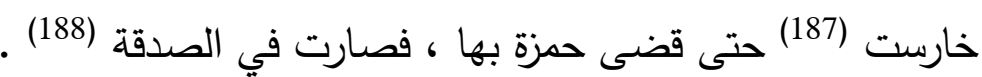
ورد في الرواية خيف ليلى وبسطاس وأراك ، بحثت عنهم ولم أجدهم ، وكلمة البغيبغات بحثت عنها ولم

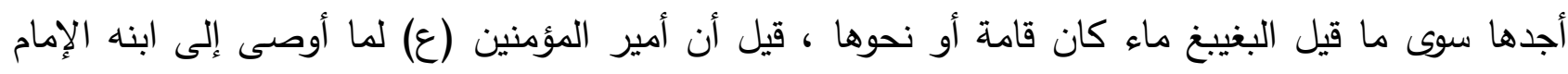

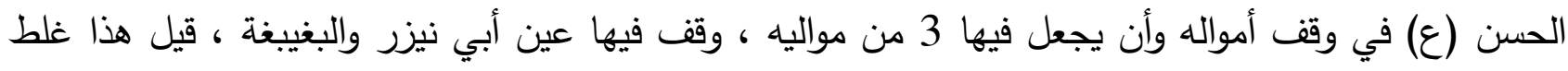

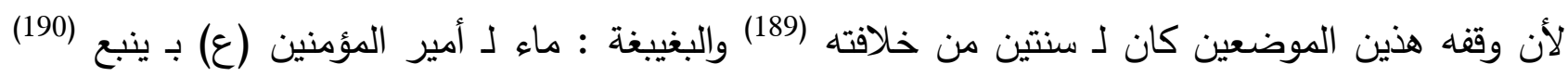

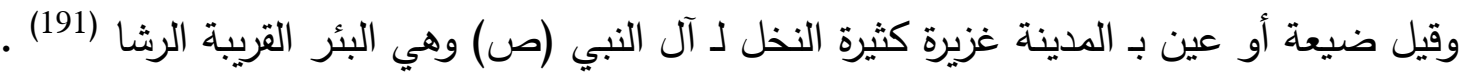

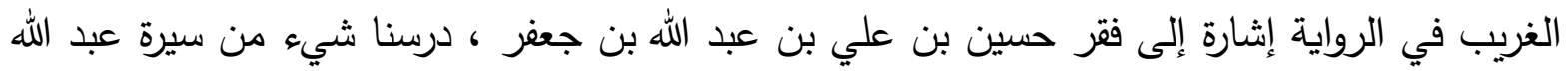

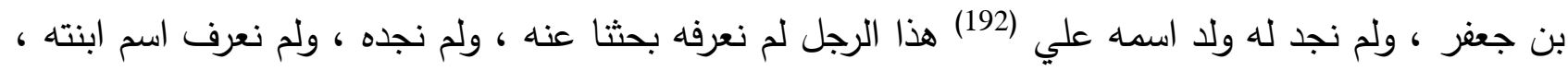
وجوده شكل ضعفاً في الرواية . وعين الحدث غير معروفة ، راجعنا مدينة الحدث عند ياقوت الحموي ولم نجد فيها العين (193) ولا كذلك

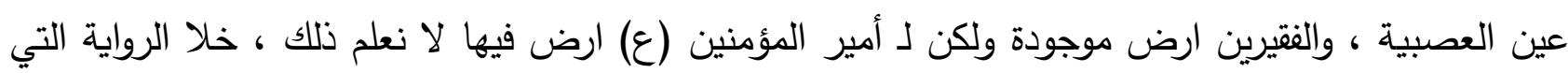

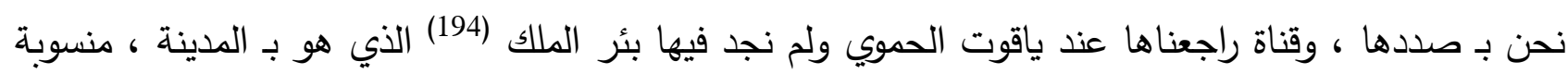

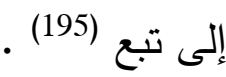
ول أمير المؤمنين (ع) أيضاً حق على عين سكر ، وله أيضا ساقي على عين بـ البيرة وهو في الصدقة

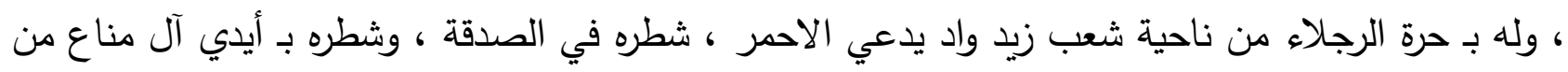

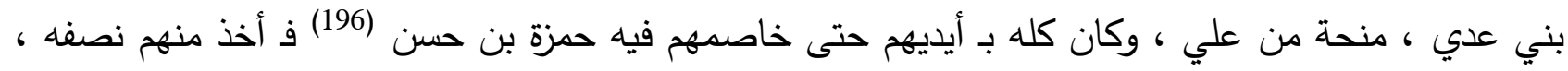

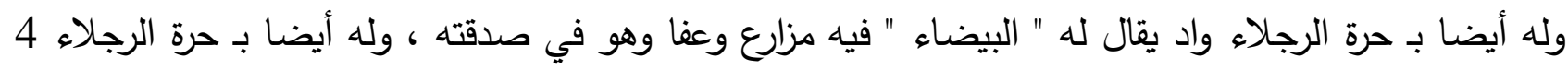

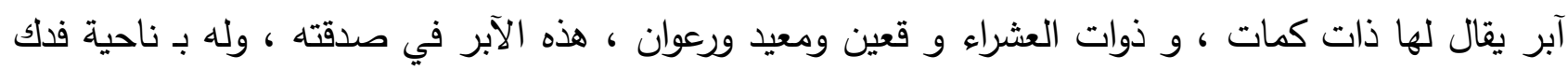

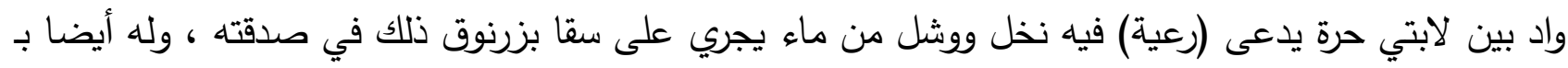

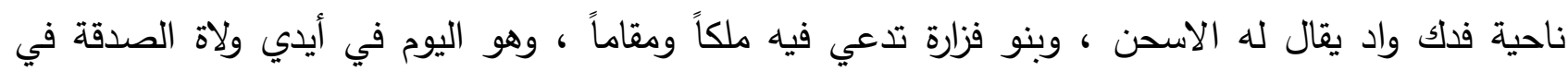


(197)

الصدقة ، وله أيضا ناحية فدك مال بـ أعلى حرة الرجلاء يقال له القصيبة كان عبد الله بن حسن بن حسن

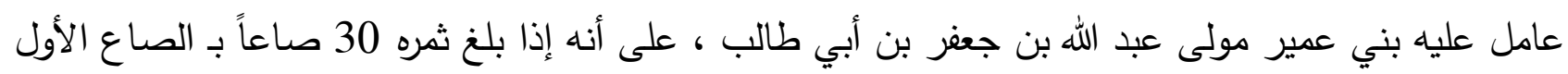

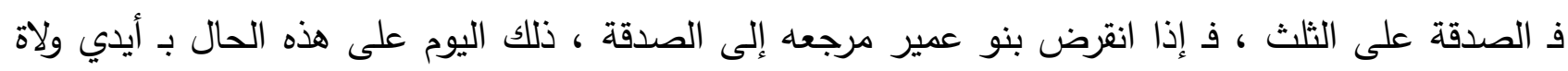

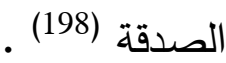

وما ورد في الرواية من عيون ، مثل عين سكر لم نعرفها ، الموجود سكر فقط ، موضع بـ شرقية

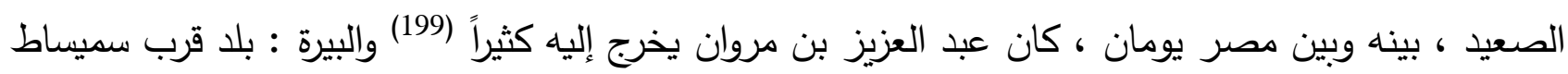

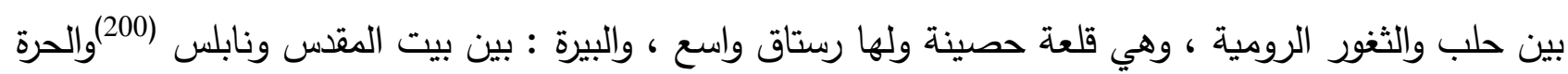

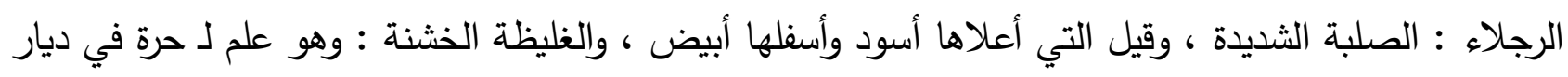

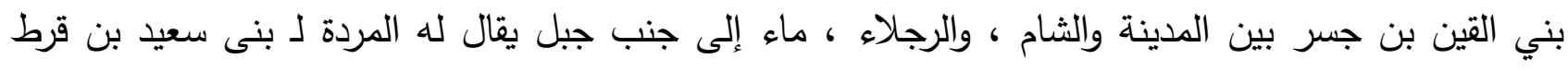

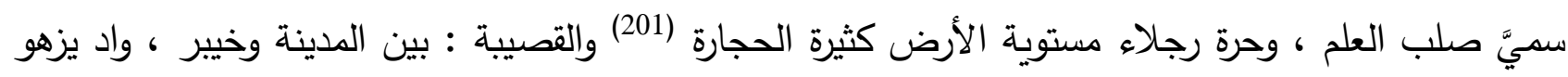

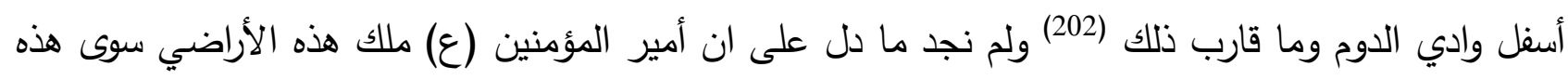

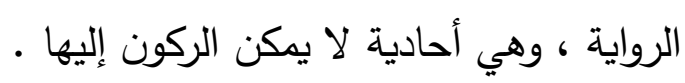
وظهر من رواية أهل البصرة ، انه ملك ارض زلركن إلهاعية واسعة ولديه عبيد ، وبهذا أصبح من رجال

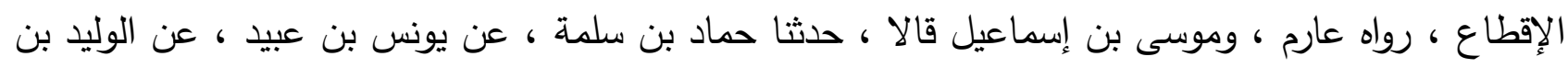

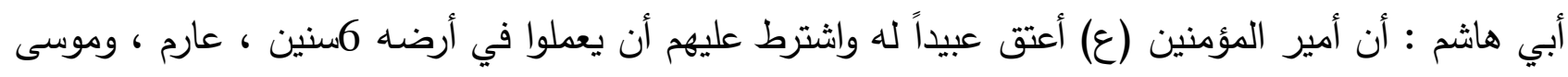

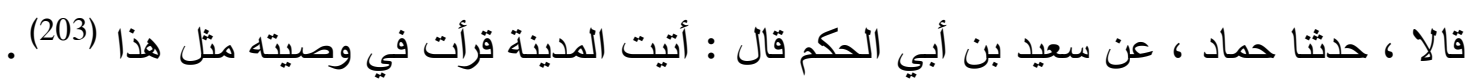

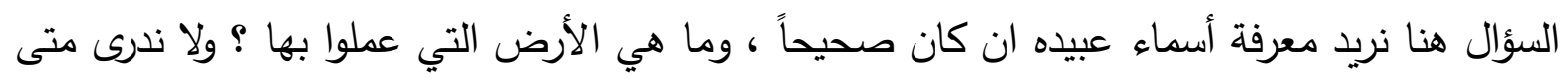

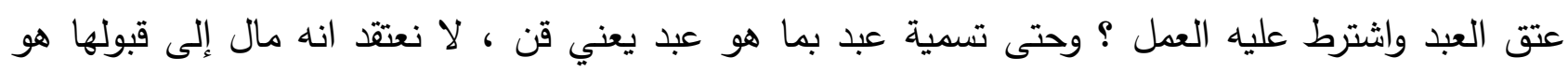
عارف تماماً ان العبودية لله وحده ، وقد بينا موقفه منها (204) .

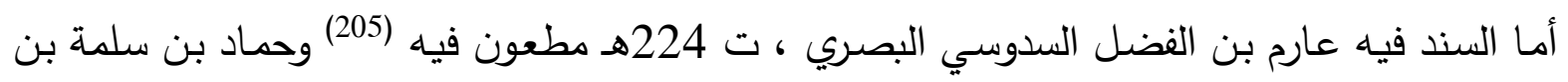
دينار البصري ت 167هـ مطعون فيه (206) ويونس بن عبيل بن دينار مولى عبد القيس من أهل البصرة ، وثقهـ

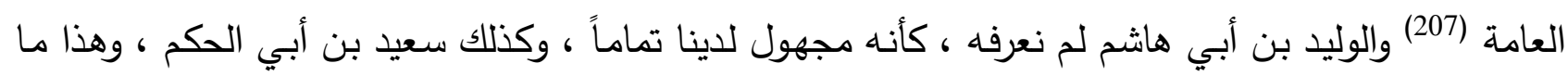
شكل ضعفاً في الرواية .

\section{وصية أمير المؤمنين (ع) بـ صدقاته}

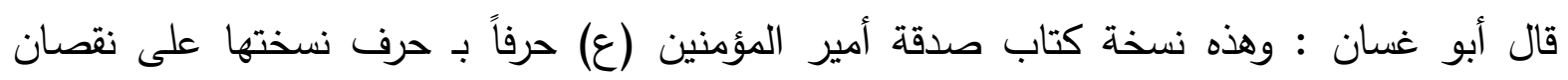

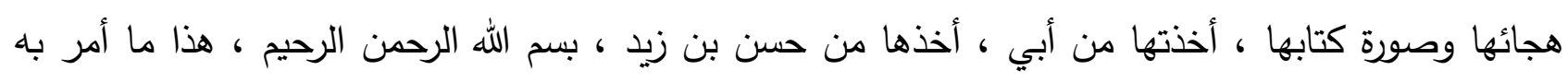

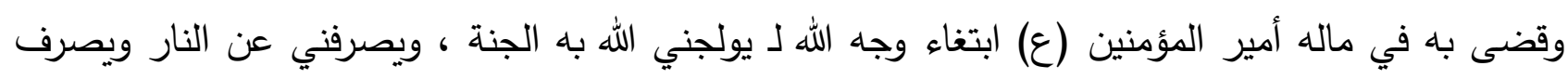

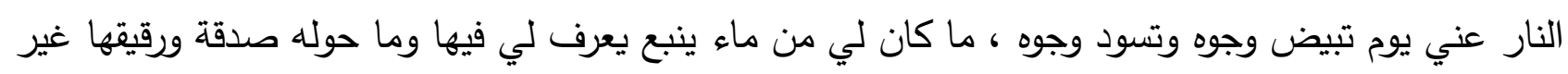

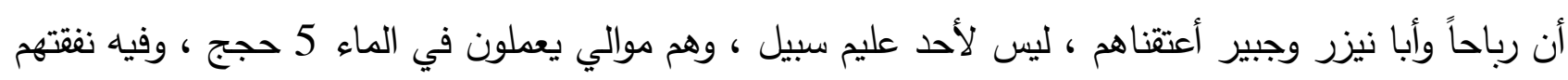




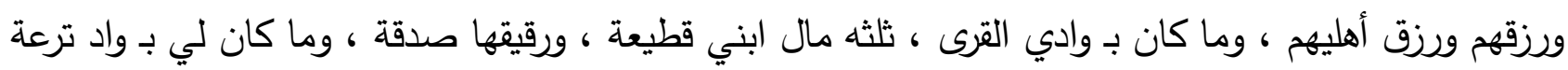

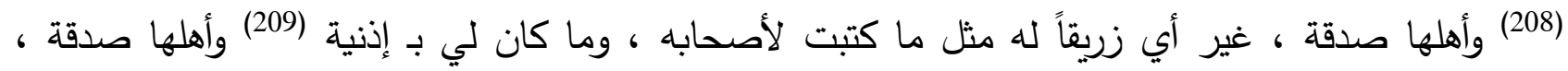

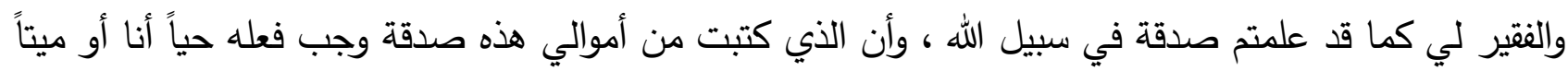

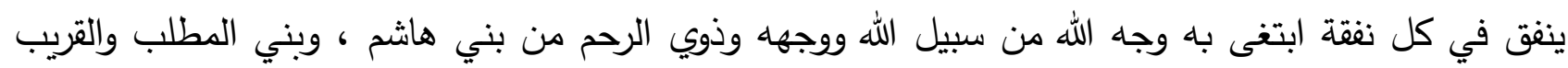

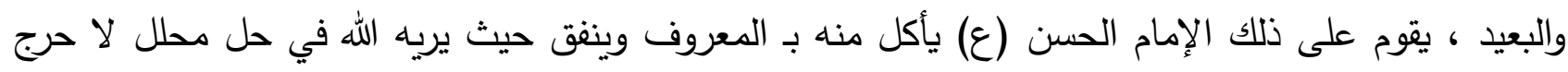

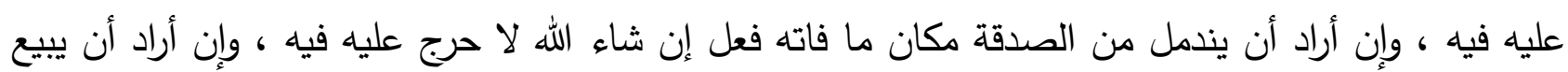

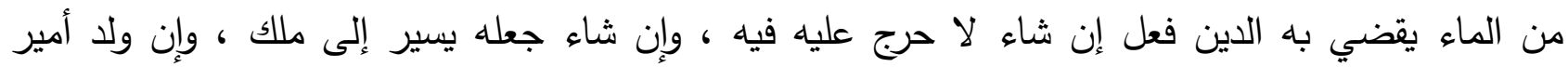

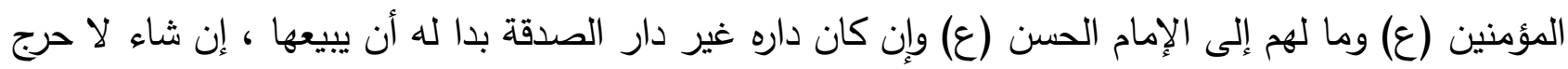

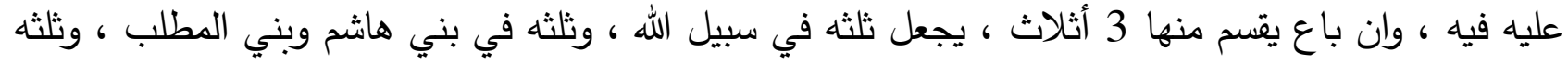

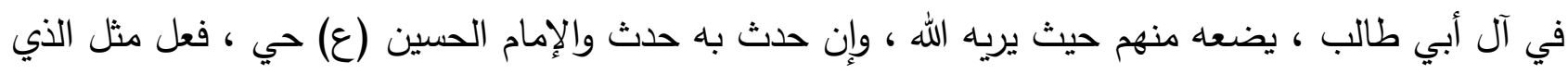

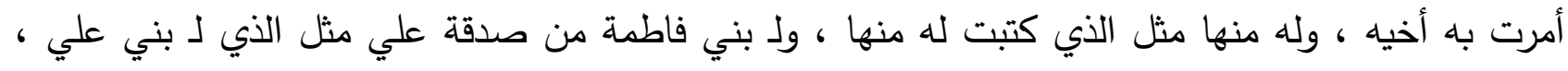

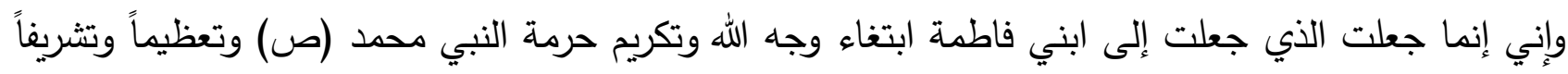

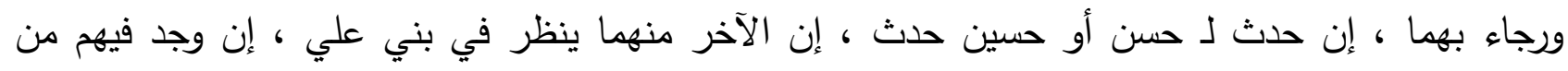

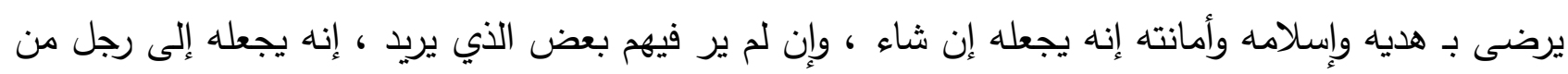

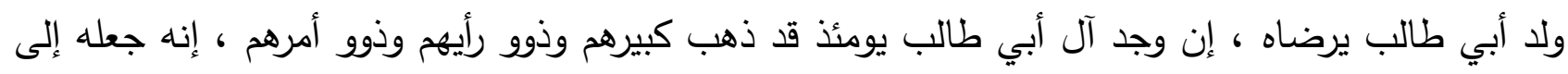

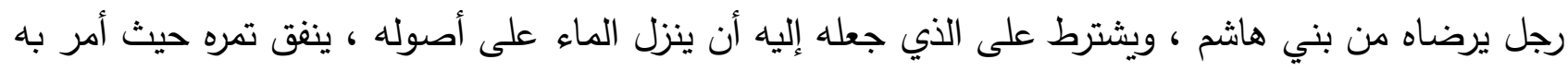

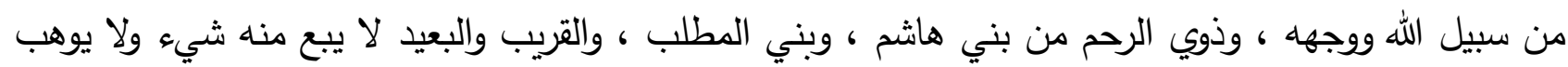

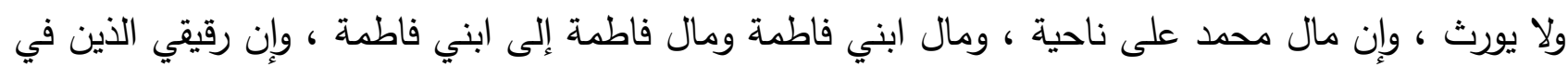

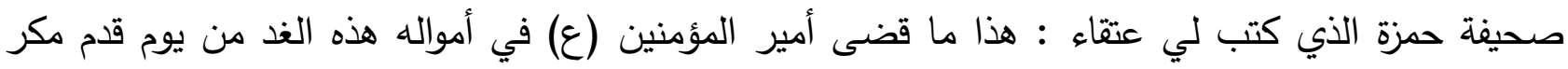

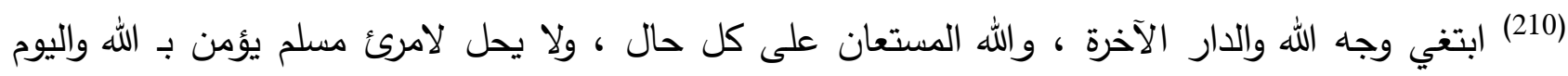

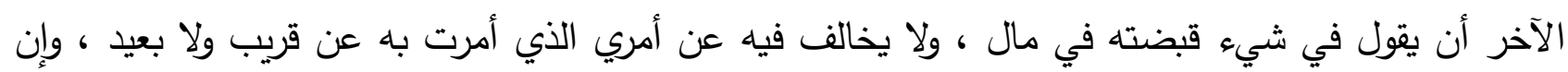

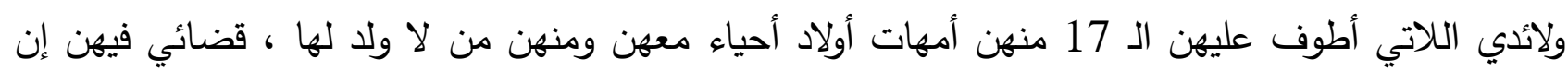

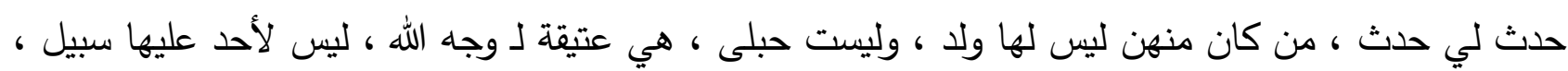

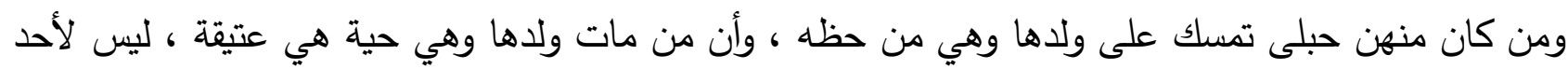

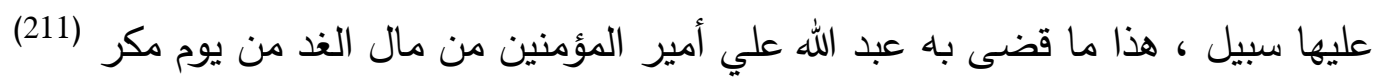

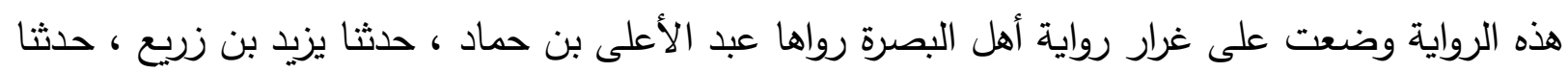
سعيد بن أبي عروبة عن قتادة ان أنس بن مالك حدثه قال : كان النبة ولبي 2 يطوف على على نسائه في الليلة الواحدة

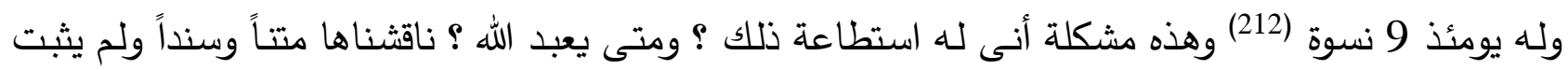
صحتها (213) 


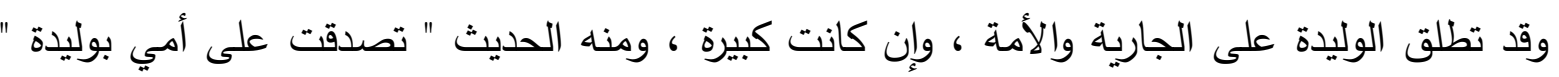

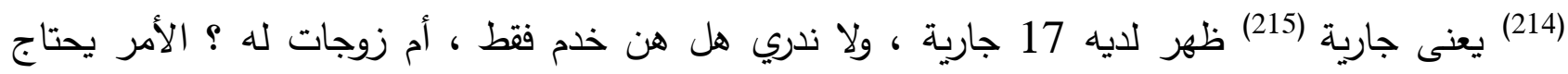

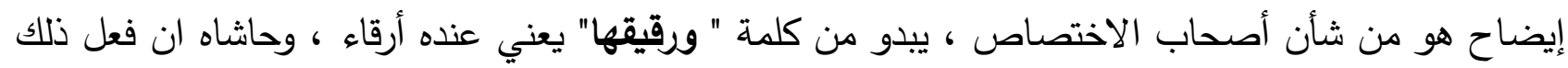

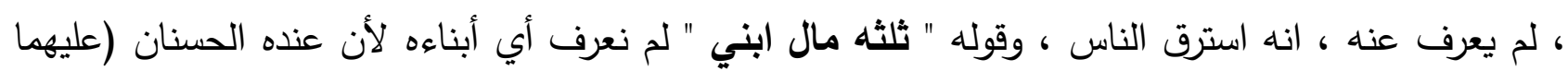

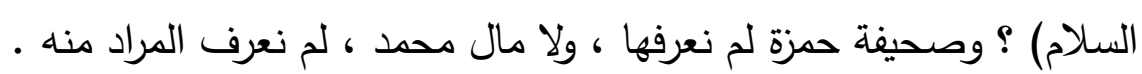

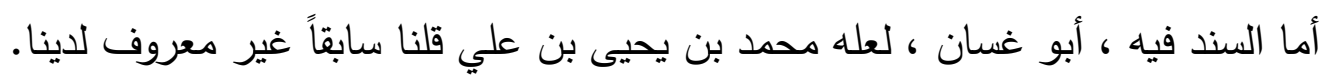

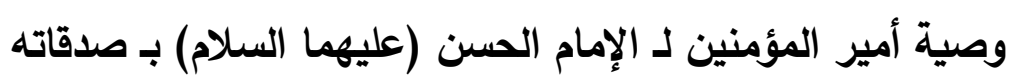

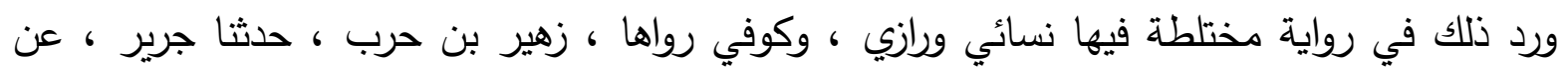

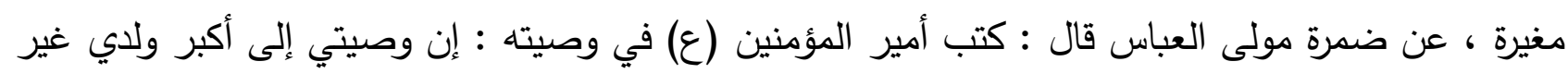

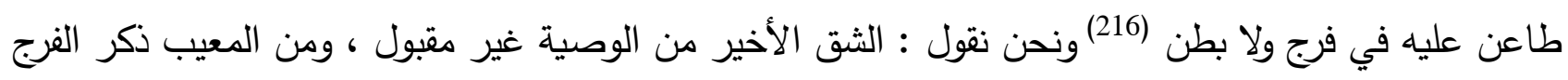

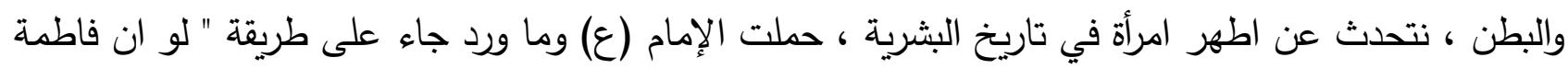

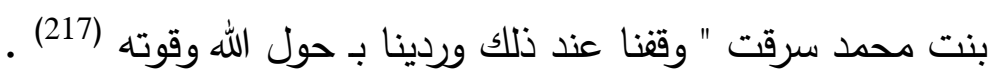

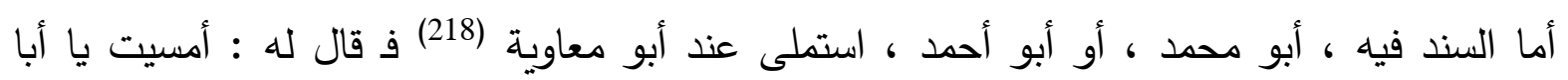

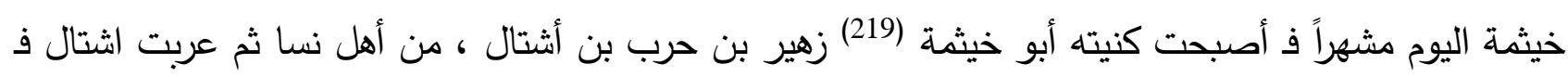

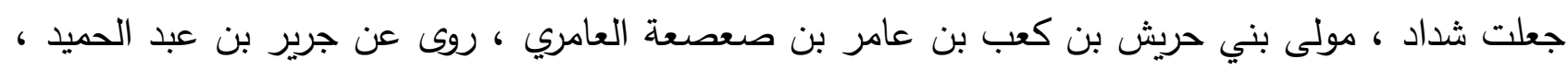

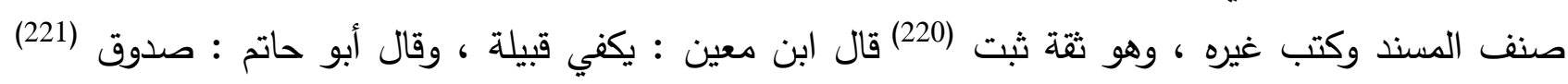
متقن ضابط من أقران ابن حنبل ويحيى (222) . قيل لـ أبي داود : هل هو حجة في الرجال ؟ قال : ما كان أحسن علمه (223) ثقة ثبتاً حافظاً متقناً ،

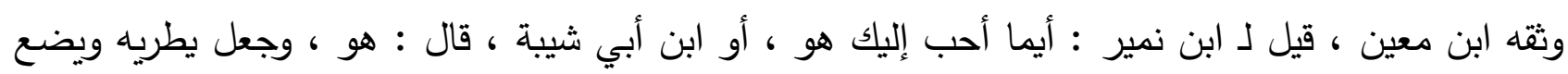

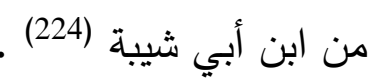
أخرج البخاري في الحج والبيوع (225) الحافظ الكبير محدث بغداد (226) الحجة ، أحد أعلام الحديث ،

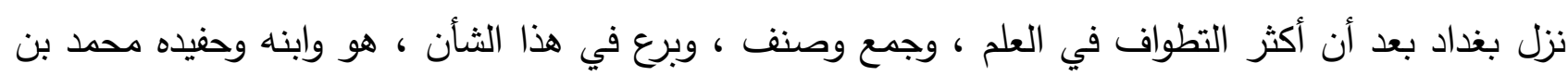

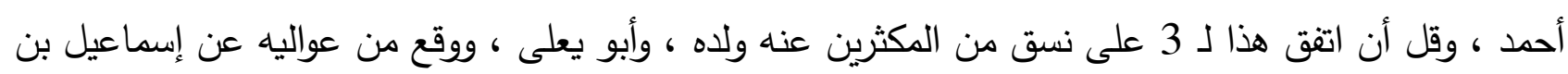

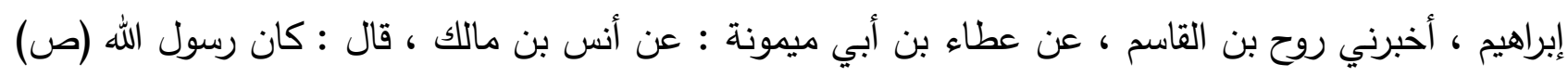

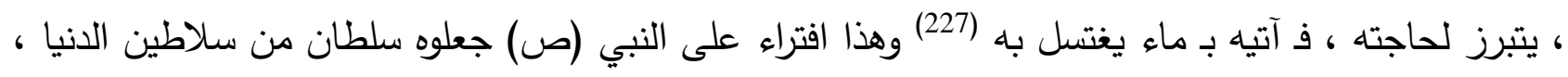

وحتى هم لم يفعلوا ذلك .

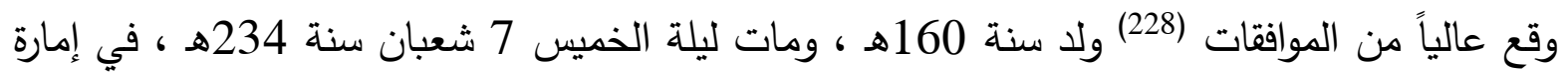

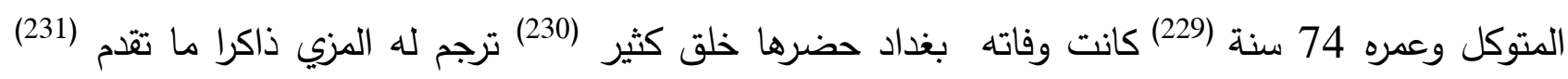

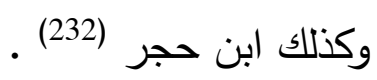




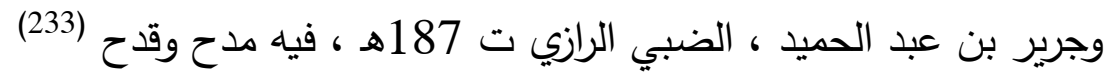

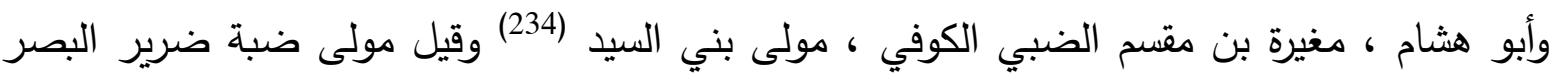

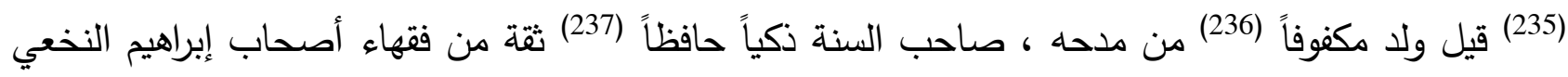
فقيه الحديث (238) . فئل قال المعتمر بن سليمان (239) : كان أبي يحثى على حديث مغيرة عنده كتاب ، قيل أحفظ من الحكم ،

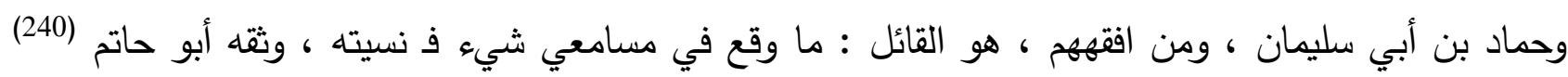

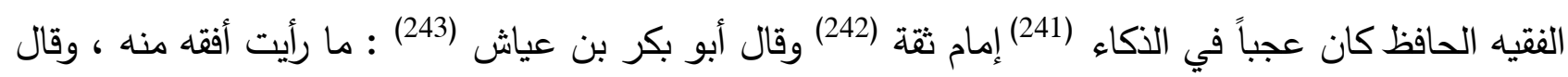
أبو حاتم ، وابن معين : ثقة مأمون (244) .

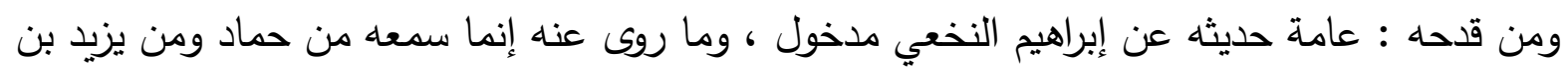
الوليد والحارث العكلي وعن عبيدة وعن غيره ، حديثه عن المغيرة عن إبراهيم وحده ضعيف (245) كان عان عثمانياً

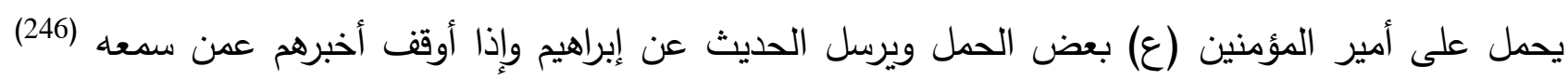

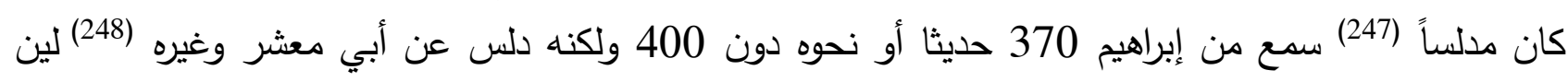

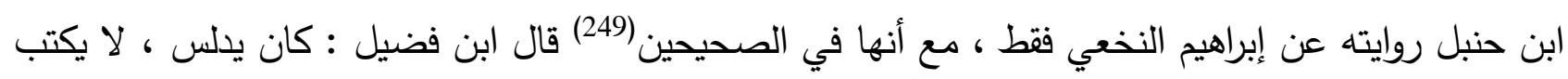

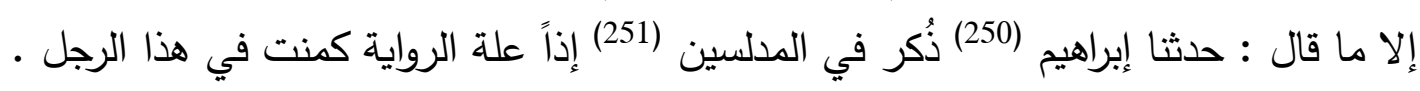

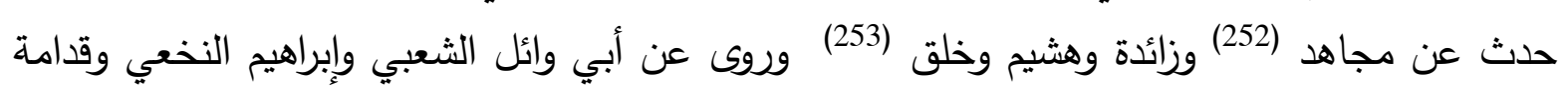

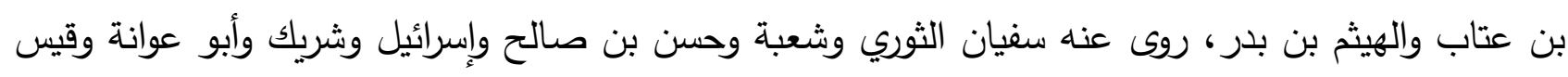

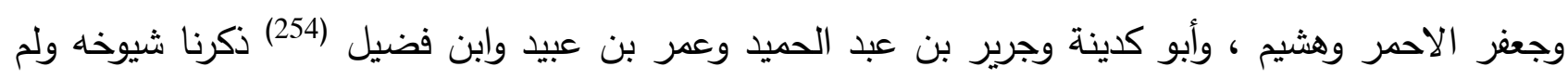

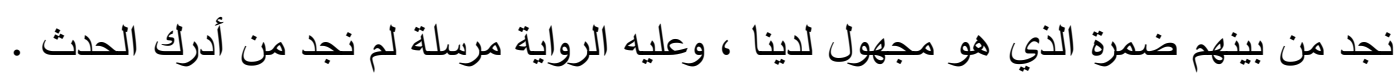

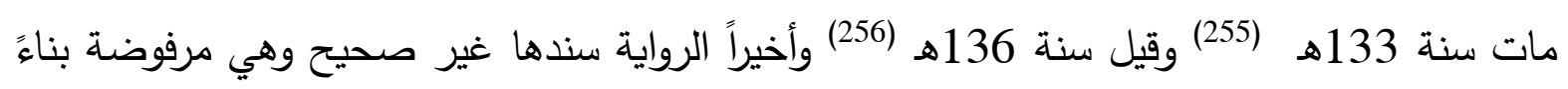
على ما تقدم مات

\section{الثهود على الوصية}

الوصية كتبنا عنها في وقت سابق في اللغة والقرآن والأحاديث لا داع لذكرها الآن ونكتفي بـ الإشارة

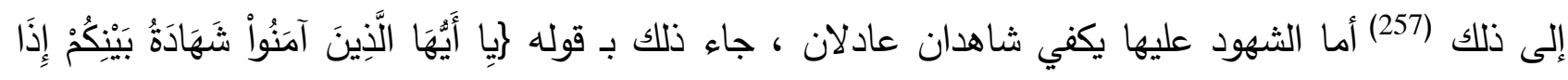

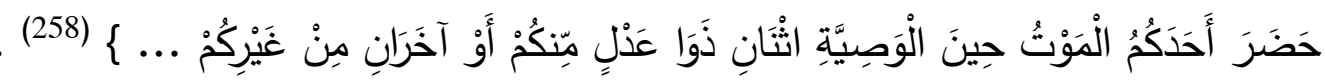

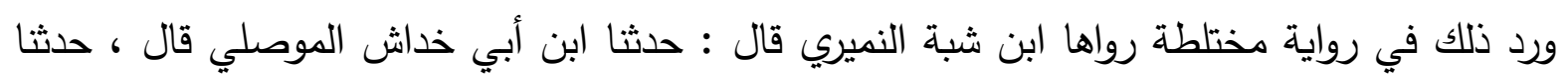

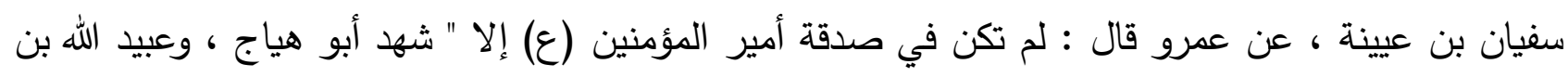

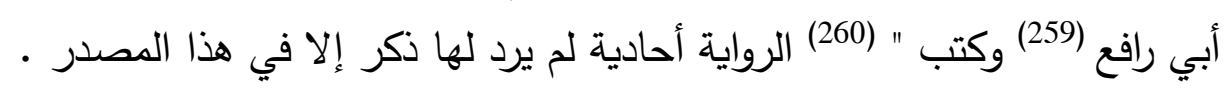

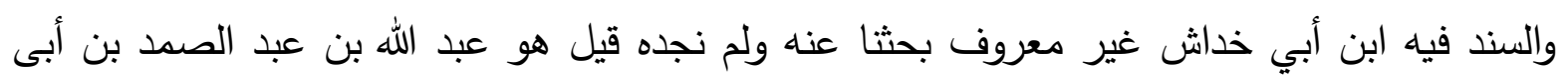

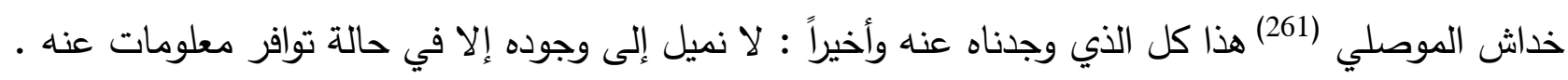


وسفيان بن عيينة الكوفي المكي مطعون فيه (262) وعمرو بن دينار المكي ، ت 126هـ ، وثقوه (263) وبهذه الوفاة يكون أرسل الرواية ولم يدرك سنة 38هـ التي نتحدث عنها ، الفارق الزمني بينهما 88 سنة ، وهذه دونه

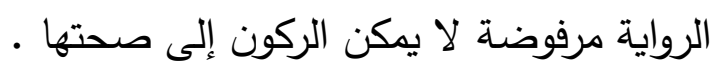
وإذا كان الثهود 2 قرآنياً ، وفي الرواية السابقة ، ورد ما ينافيهما قيل هما 4 من صحابة أمير المؤمنين

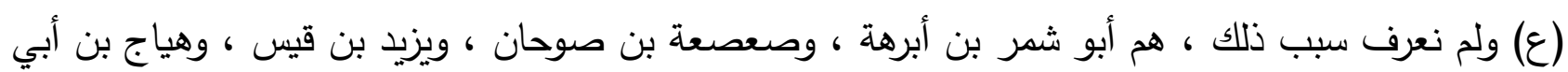

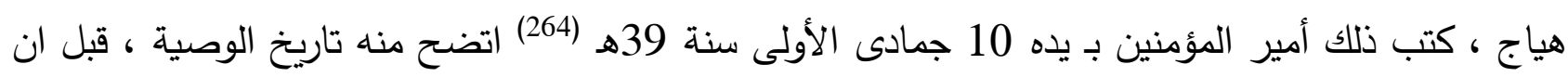

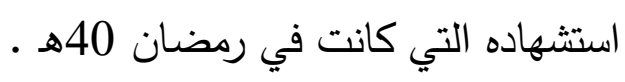
وهذا يتطلب معرفة أحوال الثهود بـ شكل مختصر ، ولو ، ولت ترجمة لأن إيضاحهم يتطلب عنوان غير الذي ندرسه ، وهم أبو شمر بن أبرهة بن الصباح الحميري ، من أهل الثام ومعه رجال منهم لـ حقوا أمير المؤمنين

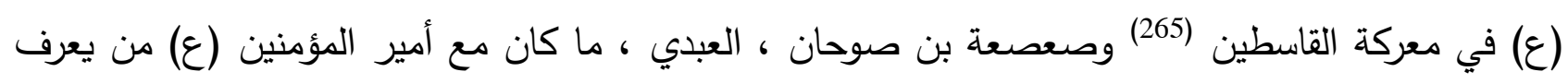

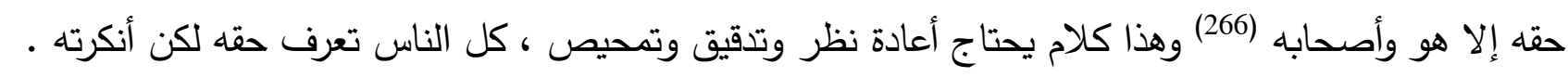

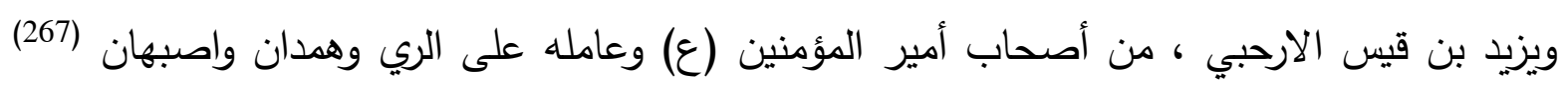

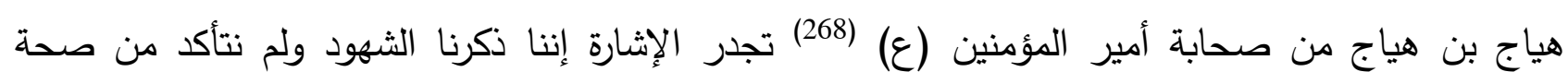

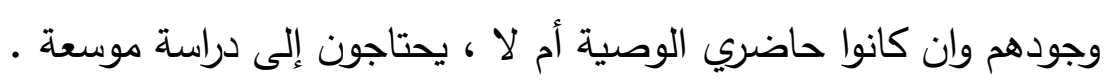

\section{Conciusion} الخاتمة

1- المال مذموم قرآنياً ، وحاشا الإمام الحسن (ع) ان يأخذ مذموماً ويشترطه في الهدنة .

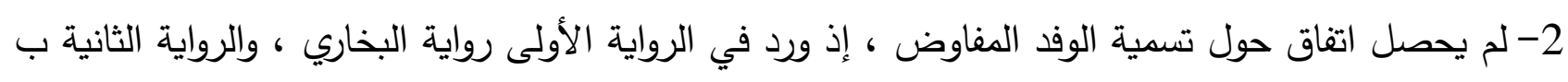

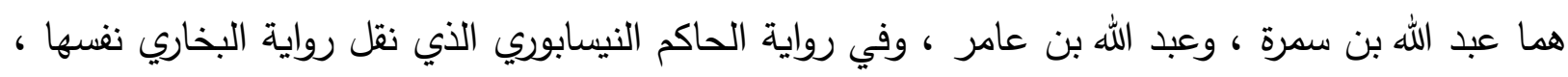

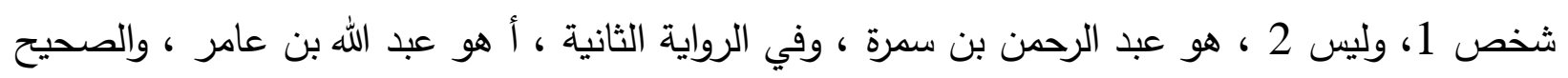

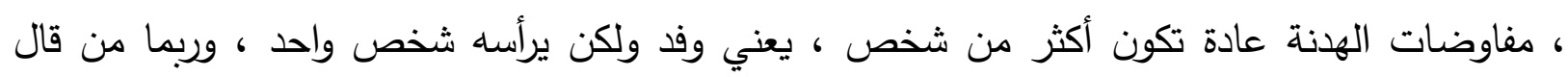

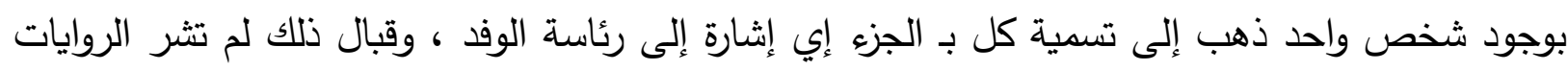

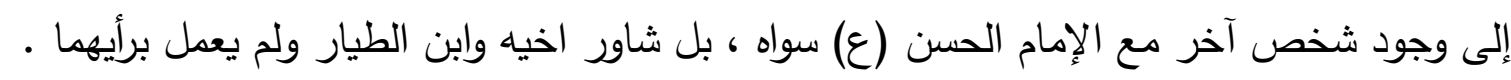

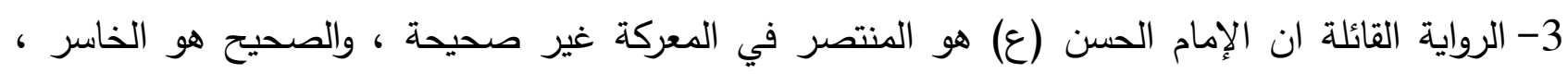

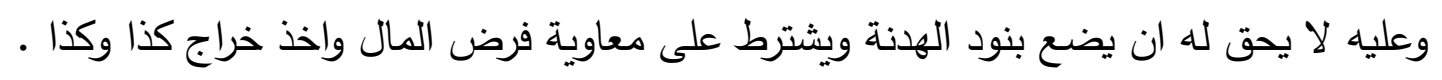
4- لم يحصل اتفاق حول كمية المال ونوعه وتحديده .

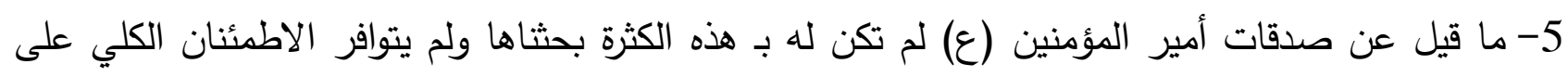
وجودها . 
قلنا في الملخص ليس من شأننا كتابتها ولكن لا بد من الإشارة إلى الى القرآن الكريم راضي آل ياسين ، الثيخ الثرب

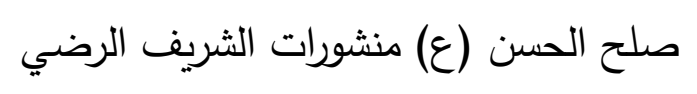
سامي البدري ، السيد

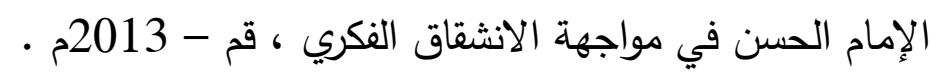

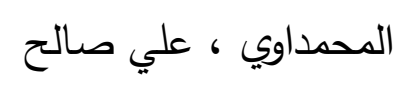

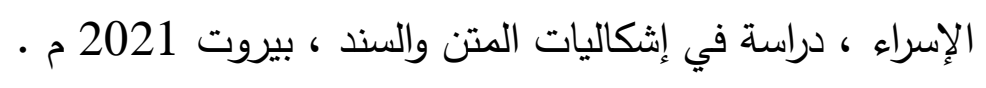

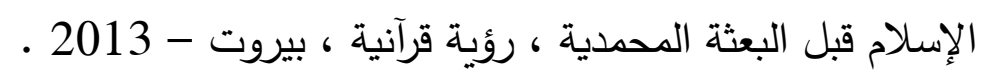

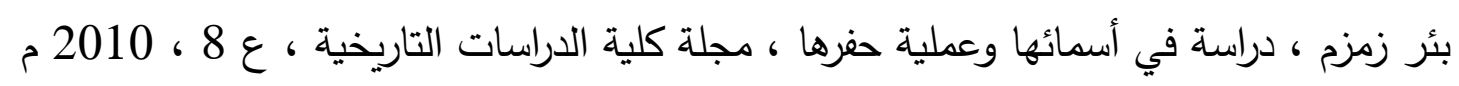

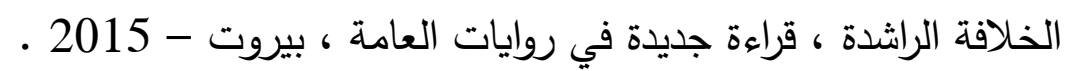

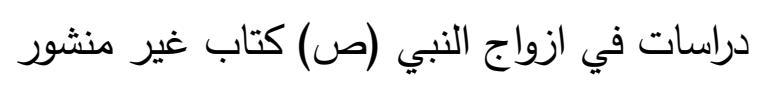

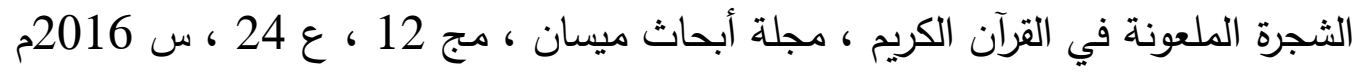

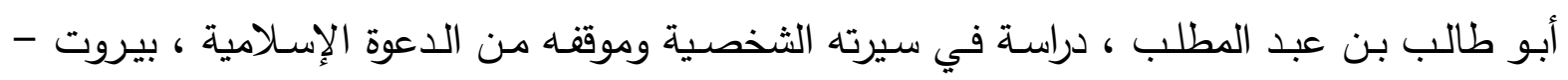

$$
\text { - } 2012
$$

عبد المطلب ، دراسة في اسمه ونسبه ، مجلة دراسات تاريخية ، ع 13 ، ل 1 ، ، 2012م .

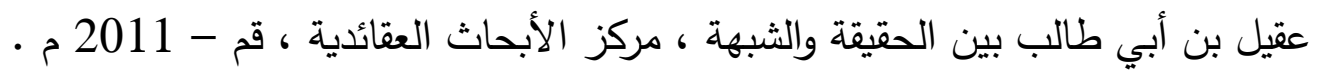

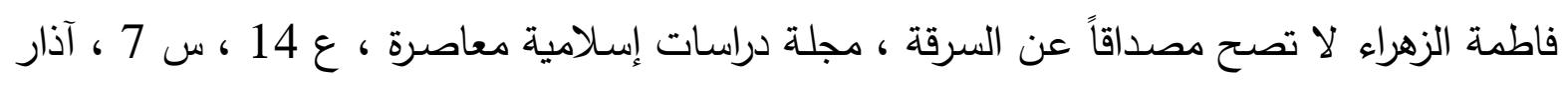

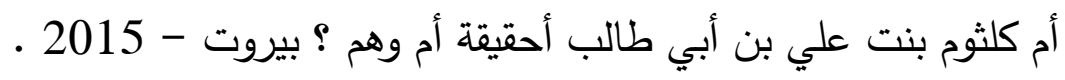

$$
\begin{aligned}
& \text { كوفيون تحت مطرقة الجرح والتعديل ، كتاب غير منشور }
\end{aligned}
$$

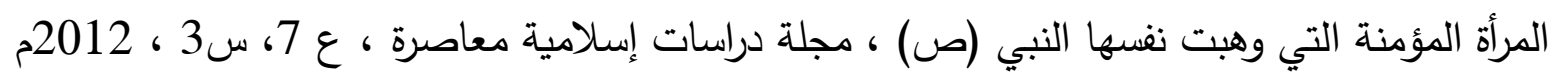

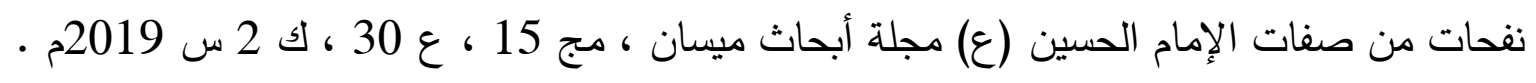

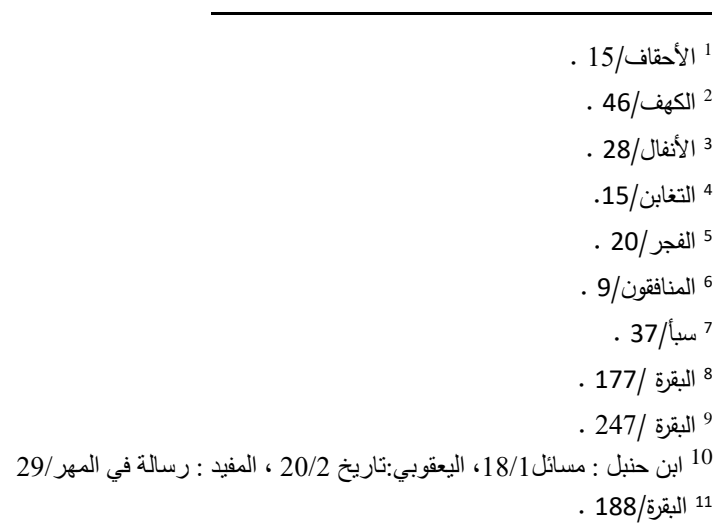




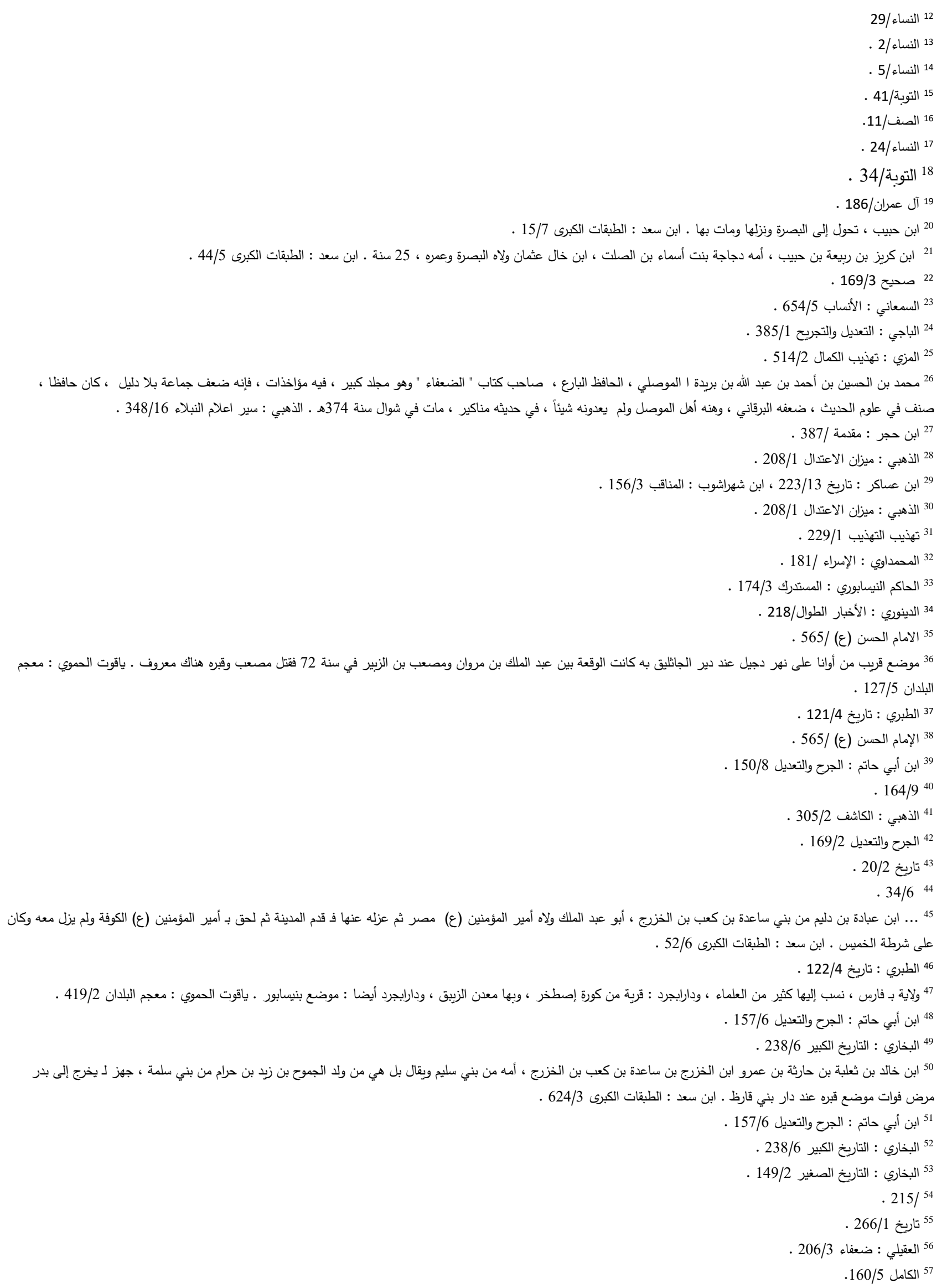




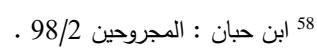

59 ابن حنبل : العلل $51 / 3$ ابن حيان : الدروحن

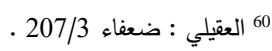

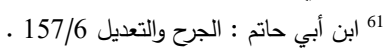

62

. 51/3 العلارئ.

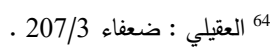

. 96/2 ${ }^{65}$

66 ابن حجر : طبقات المدلسين/56/267 ، سبط ابن العجمي : التببين لأسماء المدلسين/41 .

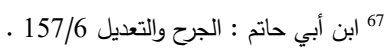

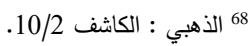

69 ابن حبان : الثنقاة 199/7 الكائ

70 ابن أبي حاتم : الجرح والتعديل 156/6 ، ينظر البخاري : التاريخ الكبير 237/6.

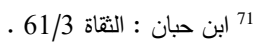

1069/3 الباجي : التعديل والتجريح 132 . 157/5

74 البخاري : التاريخ الكبير 237/6 .

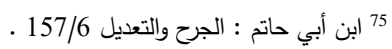

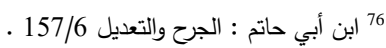

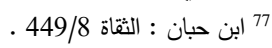

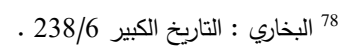

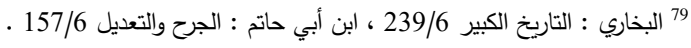

80

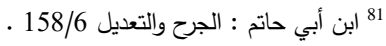

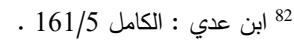

83 الذهبي : الكاشف 10/2.

84 المحداوي : الثجرة الملعونة في القرآن الكريم ، مجلة أبحاث ميسان ، مج 12 ، ع 24 ، س 2016م ، ص ص 15 ـ

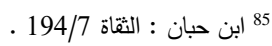

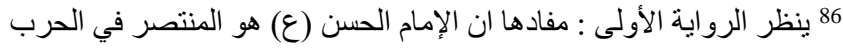

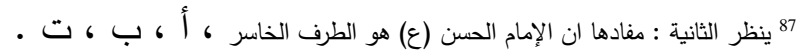

88

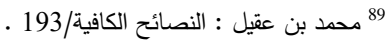

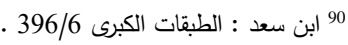

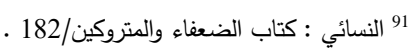

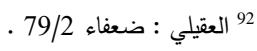

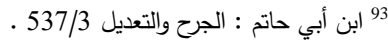

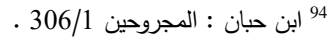

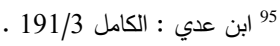

96 الذهبي : ميزان الاعتدال 91/295 .

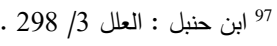

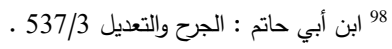

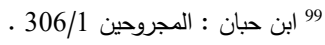

100

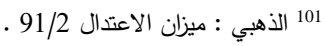

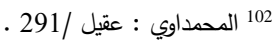

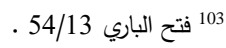

الذهبي : سير أعلام النبلاء 47/18 فياري 103

105 الصدوق : علل الثرائع 211/1 التهب التلاه

106 ابن منظور : لسان العرب 386/8 ـ الترائ 
108 109

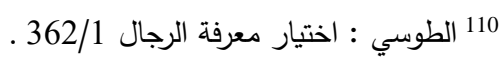

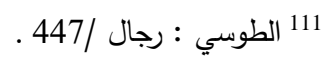
112 الطوسي : الفهرست/208

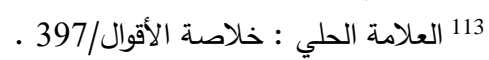

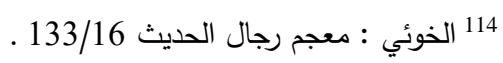

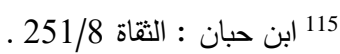
116 الخطيب البغدادي : تاريخ بغداد 111 بن

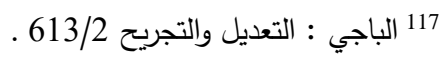

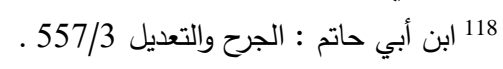
119 الذهبي : تذكرة الحفاظ ابن حاتم : الجرح ولعديل

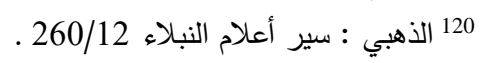
121 ابن حجر : تهذيب التهذيب 340/3 ـ

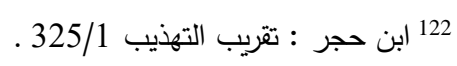

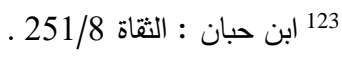

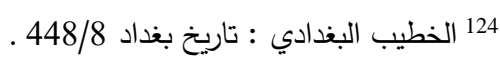

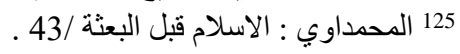

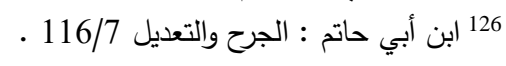
127 ابن معين : تاريخ 116/2 ، ابن أبي شيبة : سؤالات /61 ، ابن حنبل : العلل 399/1 ؛ 39 ، العجلي : الثقاة 211/2 ، ابن حبان : الثقاة . 128 ابن شاهين : الثقاة / 190

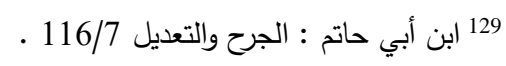
130 المزي : تهذيب الكمال 131 الذهبي : ميزان الاعتدال 132130 132 133 الآجري : سؤالات 134 134 الآجري : سؤالات 135/2/102. . 477/3 135

136 ابن حبان : مشاهير علماء الأمصار/251 .

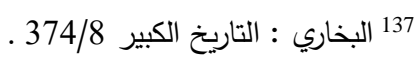
138 ابن أبي حاتم : الجرح والتعديل 230/9 ـ التخيل 139 ابن حبان : الثن الثي حان : الثرح ولتعديل

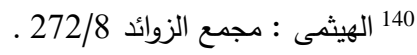

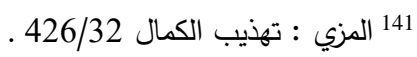
142 143 ابن كثير : تفسير 566/4 من أحس 144

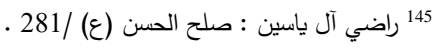

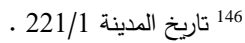




\section{هبلة أبحاث هيسان، المجلد السابع عشر، العدد الرابع والثلاثون، كانون الاول، السنة 2021}

https://doi.org/10.52834/jmr.v17i34.68

148 اسم قرية قرب وادي الصفراء من أعمال المدينة وفيه عين كبيرة تخرج من جوف رمل من أغزر ما يكون من العيون وأكثرها ماء وتجري في رمل لألا يستطيع الزارعون عليها إلا في مواضع يسيرة

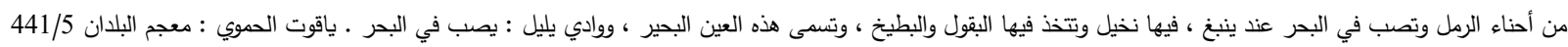

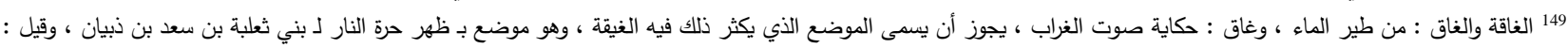

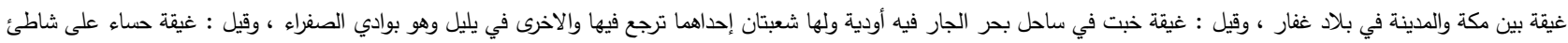

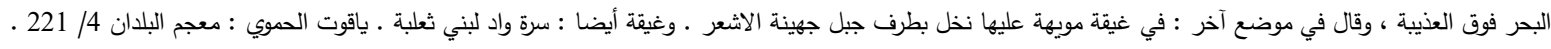

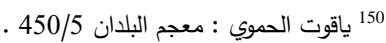
151 ابن عساكر : تاريخ 150

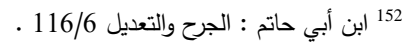

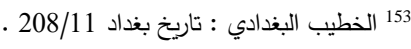

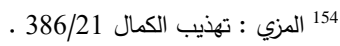

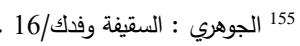
156 الخطيب البغدادي : تاريخ بغداد 155 الجوري : 208/11 . 157 الخطيب البغدادي : تاريخ بغداد 156 الخيخ ليذاد 208/11 .

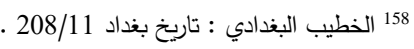

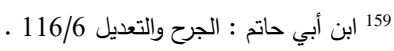

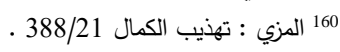
161 الخطيب البغدادي : تاريخ بغداد 164 التريب الكال

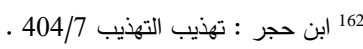

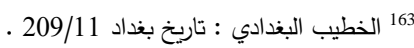

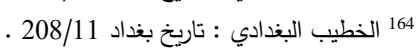

165 سير أعلام النبلاء 164

166 الذهبي : سير أعلام النبلاء 369/12 الناه

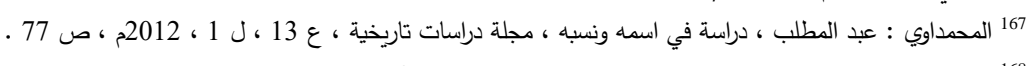

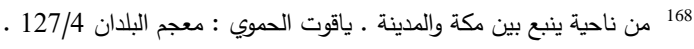

169 ابن شبة النميري : تاريخ المدينة 221/1 .

170

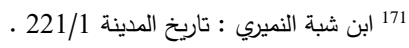

172

173

174

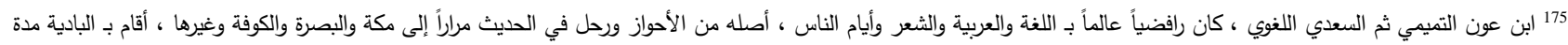

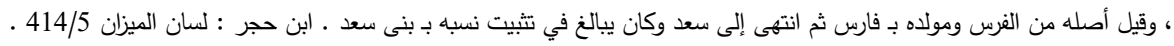

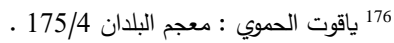

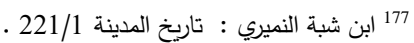
178 178 179 180

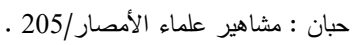

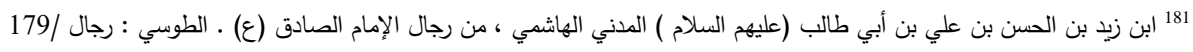
182

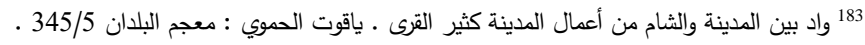

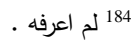

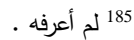

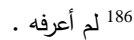

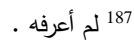

188 ابن شبة النميري : تاريخ المدينة 222/1 . 189

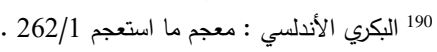

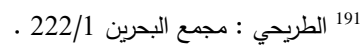
192 


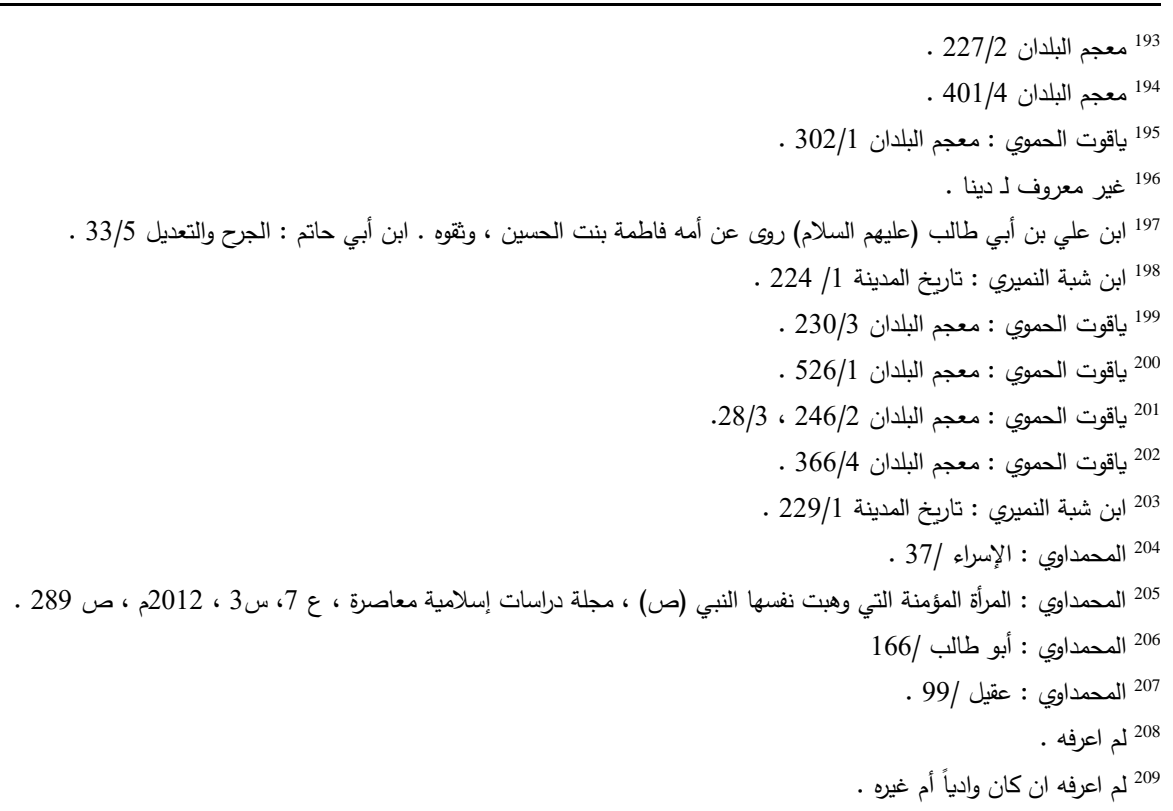

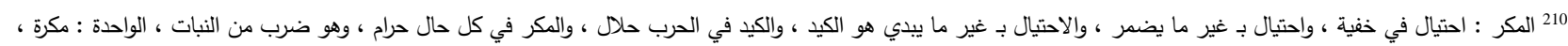
سميت لارتوائها ، والمكر : حسن خدالة الساق ، فهي مرتوية خدلة ، شبهت بـ المكر من النبات ، والمكر : المغرة ـ الفراهيدي : العين

211 ابن شبة النميري : : تاريخ المدينة : 225/1 .

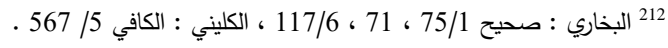

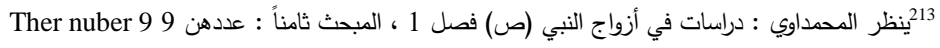
214 ينظر نص الحديث عند أبو داود : سنن 658/1 .

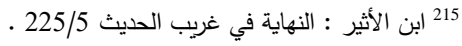

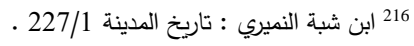

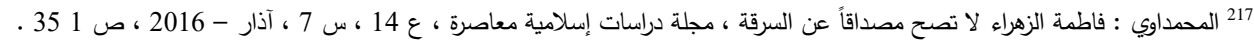

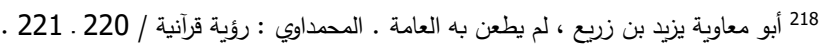

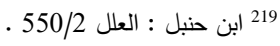

220 ابن سعد : الطبقات الكبرى $354 / 7$ ـ

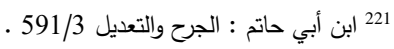
222 223 الآجري : سؤالات 293/2 النيان :

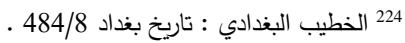
225 الباجي : التعديل والتجريح 627/2 . 226 الذهبي : تذكرة الحفاظ 437/2 ـ لتعديل ولجريح

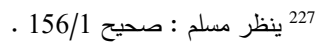

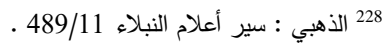

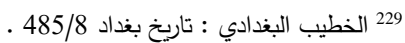
230 ابن سعد : الطبقات الكبرى 354/7 ـ تاريب لغخاد 231 تهذيب الكمال 402/9 - 406 الطندات الكبري 4062 232 233 ينظر المحمداوي : كوفيون تحت مطرقة الجرح والتعديل ، الفصل الثاني ، رقم الترجمة 3 .

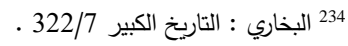
235

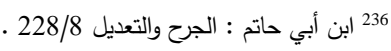
237 ابن حنبل : العلل 207/1 ابن حات : 238

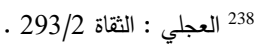

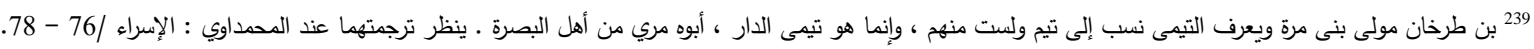

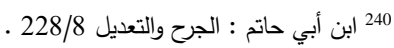

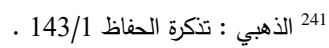
242 


\section{هبلة أبحاث هيسان، الجبلد السابع عشر، العدد الرابع والثلاثون، كانون الاول، السنة 2021}

https://doi.org/10.52834/jmr.v17i34.68

كُ3243 كوفي اختلف في اسمه ، والصحيح اسمه كيته ، محباً الثيخين ، فيه مدح وقدح ، ت 193هـ . المحداوي : نفات من صفات الإمام الحسين (ع) مجلة أبحاث ميسان ، مج 15 ، ع 30 ،

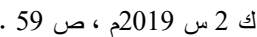

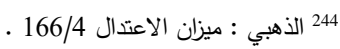
245 245

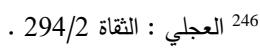

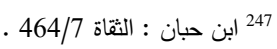

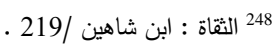

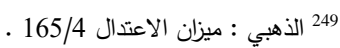

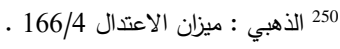

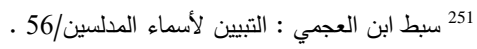

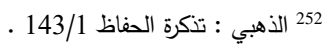

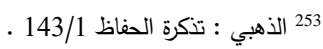

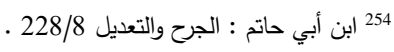
255 256 العجلي : الثقاة 293/2 البخاري : التاربخ الكير

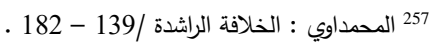
258

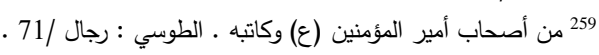

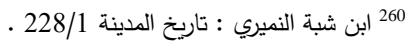

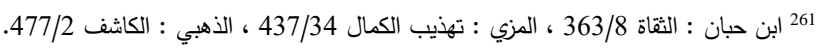
262

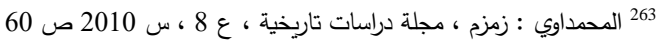

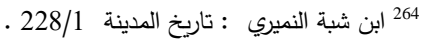
265 266

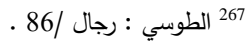

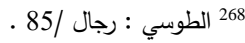

